\title{
A taxonomic revision of the Campanula lusitanica complex (Campanulaceae) in the Western Mediterranean region
}

\author{
by \\ Jara Cano-Maqueda \& Salvador Talavera \\ Departamento de Biología Vegetal y Ecología, Universidad de Sevilla, E-41080 Sevilla, Spain. Corresponding author: stalavera@us.es
}

\begin{abstract}
Cano-Maqueda, J. \& Talavera, S. 2011. A taxonomic revision of the Campanula lusitanica complex (Campanulaceae) in the Western Mediterranean region. Anales Jard. Bot. Madrid 68(1): $15-47$.

The systematics of the annual species of the Campanula lusitanica complex in the Western Mediterranean is reviewed using ITS sequences, karyology and morphology of all species of the complex. The information provided by these three sources is consistent, and the species are reorganized into two groups with the rank of section: Campanula sect. Rapunculus Boiss. and Campanula sect. Decumbentes, the latter described as new in this work. These sections comprise two well-defined subclades in the phylogenetic analyses. Sect. Rapunculus is composed, in the W Mediterranean region, by C. Iusitanica L. and C. matritensis A. DC., both with $2 n=18$ chromosomes, and C. cabezudoi Cano-Maqueda \& Talavera, C. specularioides Coss., C. transtagana R. Fern., and C. broussonetiana Schult., all with $2 n=20$ chromosomes. In the Iberian Peninsula, Sect. Decumbentes comprises two endemic species, $C$. decumbens A. DC. with $2 n=32$ chromosomes and C. dieckii Lange with $2 n=28$ chromosomes. In $C$. decumbens a new subspecies is described: C. decumbens subsp. baetica Cano-Maqueda \& Talavera, which occurs in the Guadalquivir valley. In the formal systematic part we provide a key to identify these annual species of the Western Mediterranean, with a description and typification, photographs of flowers and fruits, distribution maps, and comments on the habitat for each taxon.
\end{abstract}

Keywords: phylogeny, rn DNA ITS, karyology, systematic, typification.

\section{Introduction}

The genus Campanula comprises about 420 species distributed mainly in temperate regions of the Northern Hemisphere (Lammers, 2007a, b). They are usually perennial herbs, although some are shrubby, and

\section{Resumen}

Cano-Maqueda, J. \& Talavera, S. 2011. Una revisión taxonómica del complejo Campanula lusitanica (Campanulaceae) en la región occidental mediterránea. Anales Jard. Bot. Madrid 68(1): 15-47 (en inglés).

En este trabajo se revisa la sistemática de las especies anuales del complejo Campanula lusitanica en el occidente del Mediterráneo usando secuencias ITS, cariología y análisis de los caracteres morfológicos de todas las especies del complejo. La información proporcionada por estas tres fuentes de caracteres es congruente, y las distintas especies se reorganizan en dos grupos principales con categoría de sección, que se corresponden con los dos subclados bien definidos: Campanula sect. Rapunculus Boiss. y Campanula sect. Decumbentes, descrita como nueva en este trabajo. En el Mediterráneo occidental, la sect. Rapunculus está formada por las siguientes especies anuales: C. Iusitanica L. y C. matritensis A. DC., con $2 n=18$ cromosomas, y C. cabezudoi Cano-Maqueda \& Talavera, C. specularioides Coss., C. transtagana R. Fern. y C. broussonetiana Schult., con $2 n=20$ cromosomas. En la Península Ibérica la sect. Decumbentes está representada por $C$. decumbens A. DC., con $2 n=32$ cromosomas, y C. dieckii Lange, con $2 n=28$ cromosomas, ambas endémicas de la Península lbérica; de $C$. decumbens se describe una subespecie nueva: C. decumbens subsp. baetica Cano-Maqueda \& Talavera, taxon del valle del Guadalquivir muy bien diferenciado morfológicamente de la subsp. decumbens. En la parte sistemática se proporciona una clave para la identificación de estas especies anuales del oeste del Mediterráneo, así como una descripción y tipificación, fotografías de las flores y frutos, mapas de distribución, y aspectos de la ecología para cada uno de los táxones.

Palabras clave: filogenia, secuencias ITS, cariología, sistemática, tipificación.

there are also some annual herbs, the latter mainly in the Mediterranean. This genus has a high morphological complexity that is reflected in the different classifications that have been proposed.

Based mainly on the morphology of the calyx, A. de 
Candolle $(1830,1838)$ divided the genus Campanula into two sections: sect. Medium A. DC., with calycine appendages, and sect. Eucodon A. DC., without them. This classification was followed by most nineteenth century authors (e.g. Endlicher, 1838; Willkomm, 1868; Bentham \& Hooker, 1876; Rouy, 1908). In contrast, Boissier (1875) divided the genus into two sections based on fruit dehiscence: sect. Medium A. DC., with capsules opening by basal pores or valves, and sect. Rapunculus Boiss., with apical or middle position pores or valves. This classification was followed with some modifications by Fedorov $(1957,1976)$.

Perhaps the taxonomic treatment with most insight was that by Damboldt (1976) during the preparation of the Flora of Turkey. He divided the genus Campanula into six subgenera: Campanula, Megalocalyx Damboldt, Sicyocodon (Feer) Damboldt, Roucela (Dumort.) Damboldt, Brachycodonia (Fedorov) Damboldt and Rapunculus (Boiss.) Kharadze. The subgenus Campanula includes plants with 3 or 5 stigmas, with or without calycine appendages, and with the capsules opening by basal or middle position pores, or indehiscent. This is the most complex subgenus, with 12-15 recognized sections and it contains most of the species of the genus. According to Sáez \& Aldasoro (2003), subgenera Megalocalyx and Sicyocodon are annual herbs with flowers with calycine appendages and with capsules opening by basal valves; the two subgenera differ in the size of style: very long (exceeding $35 \mathrm{~mm}$ ) in the subgen. Sicyocodon, and short (less than $15 \mathrm{~mm}$ ) in the subgen. Megalocalyx. The around 15 species of these two subgenera are distributed in the Mediterranean Basin, SW Asia and Macaronesia. The subgenus Roucela comprises annual plants, with flowers without calycine appendages and capsules opening by basal valves; it consists of 5 species distributed throughtout the E Mediterranean and SW Asia, with the exception of $C$. erinus $\mathrm{L}$. which has a wider distribution. The subgenus Brachycodonia comprises only C. fastigiata Dufour, an annual plant with axillary inconspicuous flowers, without calycine appendages, and with capsules opening by three apical valves; C. fastigiata occurs on gypsum soils in Spain, N Africa, C Asia and Transcaucasia.

The subgenus Rapunculus includes annual and perennial plants, without calycine appendages, with a large campanulate or infundibuliform corolla, and with capsules opening by apical or middle position pores. Damboldt $(1976,1978)$ divided this subgenus in three sections: Pterophyllum Damboldt, Alaria Damboldt and Rapunculus. Sect. Pteropbyllum includes three species: C. primulifolia Brot. (Iberian Peninsula), C. alata Desf. (Algeria and Morocco), and
C. peregrina L. (E Mediterranean, including Cyprus, Lebanon and SW Turkey and S Anatolia); they are hispid perennial plants with large infundibuliform flowers, arranged in spikes or panicles, with capsules opening by three pores of middle position, and with winged seeds.

Sect. Alaria contains a single species, C. pterocaula Hausskn., endemic to N and C Anatolia (Turkey); it is a biennial glabrous plant, with winged stems, large flowers arranged in spiciform inflorescences, and capsules opening by apical pores.

Sect. Rapunculus contains around 50 species distributed mainly in the Mediterranean region; it comprises perennial, biennial or annual plants, glabrous or tomentose, with wingless stems, the inflorescence a panicle, or sometimes spiciform, the capsules opening by apical or middle position pores, and wingless seeds.

Recent molecular phylogenies (Eddie \& al., 2003; Park \& al., 2006; Roquet \& al., 2008, 2009; Cellinese \& al., 2009; Borsch \& al., 2009; Haberle \& al., 2009; Stefanović \& Lakušić, 2009) have revealed that the genus Campanula is paraphyletic. Studies by Roquet \& al. (2008) using ITS sequences, show that Campanula sect. Pterophyllum together with the genera Musschia Dumort. and Gadellia Schulkina form a clade (Musschia clade) that is sister to the Campanula core.

The Campanula core consists of two subclades: one formed by the subgenera Campanula, Megalocalyx and Roucela, together with other genera of Campanulaceae; and a second subclade comprising subgenus Rapunculus (sections Rapunculus and Alaria) and subgenus Brachycodonia, again with some other genera of Campanulaceae.

The annual species of sect. Rapunculus sensu Damboldt have two centers of diversity: the Iberian Peninsula and W Morocco, and the E Mediterranean (Greece and Turkey). The annual species of the Iberian Peninsula (which include many species names, viz. C. lusitanica L., C. broussonetiana Schult., C. transtagana R. Fern., C. matritensis A. DC., C. decumbens A. DC., C. specularioides Coss. C. cabezudoi CanoMaqueda \& Talavera and C. diekii Lange) have received diverse treatments in recent taxonomic studies, i.e as varieties of Campanula patula L. (Pau, 1921; Cuatrecasas, 1929), as subspecies or varieties of C. lusitanica L. (Pau, 1924; Sáez \& Aldasoro, 2001), or as varieties of $C$. decumbens A. DC. (López-González, 1979-1980). In all cases most taxa have been relegated to infraspecific status.

However, our detailed morpho-geographical analysis of the exsiccata available for this group (which we call the Campanula lusitanica complex) lead us to con- 
clude that not only are many of the species described by various authors valid, but that several new taxa can be recognised. Moreover, our analyses (Cano-Maqueda \& al., 2008 and the present study) based on combined analysis of ITS sequences and $\operatorname{trn}$ T-L using samples from most of the annual species of the Western Mediterranean area not only support recognition of these species, but have also revealed that the annual species of sect. Rapunculus sensu Damboldt comprise a polyphyletic assemblage.

In this study we present a formal taxonomic revision of the Campanula lusitanica complex from the Iberian Peninsula and Morocco, based on our studies of exsiccata, karylogical parameters, and molecular markers. And using information provided by the nrDNA ITS for a large number of Campanula species and allied taxa we have also attempted to place the species of Campanula sect. Rapunculus sensu Damboldt within the context of the ongoing molecular systematics of the genus Campanula.

\section{Materials and methods}

\section{Molecular Phylogeny}

Fresh material and herbarium vouchers of seven samples of the Campanula lusitanica complex (four of C. lusitanica s.str., one of $C$. decumbens, one of $C$. sparsa Friv., and one sample of C. ramosissima Sibth. \& Sm.), two samples of C. primulifolia and one of Walhenbergia bederacea $\mathrm{L}$., were sequenced for this molecular survey. Additionally, 100 sequences were taken from GenBank (Eddie \& al., 2003; Susanna \& al., 2006; Roquet \& al., 2008, 2009; Cano-Maqueda \& al., 2008; Park \& al., 2006). The list of taxa, with locality, herbarium vouchers or collector's numbers, authorities and GenBank accession numbers is shown in the Appendix I.

Genomic DNA was extracted from silica-gel-dried leaves collected in the field and from herbarium material using the DNeasy Plant Mini Kit (Qiagen) following the protocols provided by the manufacturer.

Amplification of the ribosomal ITS region (ITS15.8S-ITS2) was performed in $25 \mu \mathrm{L}$ reaction volume with $22.5 \mu \mathrm{L}$ Thermo-Start ReddyMix Master Mix, 0.5 $\mu \mathrm{L}$ of each primer, $1 \mu \mathrm{L}$ of DMSO (100\%) and $0.5 \mu \mathrm{L}$ of DNA. Forward ITS5 and reverse ITS4 primers (White \& al., 1990) were used in the amplification and sequencing processes. The polymerase chain reaction (PCR) sequence profile was one cycle of $1 \mathrm{~min}$ at $96^{\circ} \mathrm{C}$, followed by 35 amplification cycles of $10 \mathrm{~s}$ denaturing step at $96^{\circ} \mathrm{C}, 5 \mathrm{~s}$ annealing at $50{ }^{\circ} \mathrm{C}$, and 3 min elongation step at $60^{\circ} \mathrm{C}$, plus an ending cycle of $8 \mathrm{~min}$ at $72^{\circ} \mathrm{C}$.

Amplified products were purified using the QIAquick PCR Purification Kit (Qiagen) according to the manufacturers protocols. Purified products were sequenced in both directions. The sequence PCR profile was of a time of incubation of $15 \mathrm{~min}$ at $37^{\circ} \mathrm{C}$ and 15 min at $80{ }^{\circ} \mathrm{C}$.

The direct and reverse sequences of each sample were compared and corrected using the program Geneious 4.8.3, obtaining the respective consensus sequence. Sequences were aligned using the algorithm of the program ClustalX, and then adjusted manually using the options of the program Se-Al v. 1.0 alpha 1 (Rambaud, 1996). Gap indels were coded as binary characters by their presence/absence $(0 / 1 \mathrm{ma}-$ trix). Only those gaps that were unambiguous and potentially informative (Torrecilla \& Catalán, 2002) were added to their correspondent sequence matrix and used for parsimony-based analysis.

\section{Phylogenetic analyses}

The phylogenetic analyses were based on parsimony and Bayesian inference searches, which were respectively conducted with PAUP* v. 4.0 beta 10 (Swofford, 2002) and MRBAY ES v. 3.0 (Huelsenbeck \& Ronquist, 2002) using Galactites tomentosa Moench. (Compositae) to root the trees.

In the parsimony analysis, the data matrix was subjected to two heuristic searches (first search: closest, TBR, MULTIPARS ON; second search: randomorder-entry of 10,000 replicates, TBR, MULTIPARS OFF, saving no more than 10 trees of score $>10$ per replicate) aimed at finding different putative islands of most-parsimonious trees. Bootstrap support for the best trees found under the parsimony criterion was estimated by heuristic search with 1,000 bootstrap replicates (Felsenstein, 1985) using the TBR and MULTIPARS OFF strategy proposed by DeBry and Olmstead (2000) to reduce the tree-search effort in bootstrap resampling analysis. Initial MaxTrees setting was 300,000 with an auto-increase of 100. Previous to the Bayesian inference search, 24 models of nucleotide substitution were tested for which the optimal model GTR $+\mathrm{G}+\mathrm{I}$. The Bayesian analysis was performed through 1,100,000 generations using the Markov chain Monte Carlo (MCMC), sampling trees every 100 generations and burn-in all sampled point from generations previous to convergence to a stable likelihood value (Huelsenbeck \& Ronquist, 2002; Leaché \& Reeder, 2002). From each search, a 50\% majority-rule consensus tree that showed de posterior-probability values of branches was constructed.

\section{Karyological study}

Plants or seeds of each taxon of the Campanula lusitanica complex sensu Cano-Maqueda \& al. (2008), 
were collected from natural populations (Table 1) and cultivated in the greenhouses of the University of Seville. Chromosomes were observed from meristematic cells of root tips or meiosis in the anthers of flower buds. The root tips were treated with 8-hidroxiquinoleine $0,002 \mathrm{M}$ for three hours and a half at $4{ }^{\circ} \mathrm{C}$. Subsequently, roots and flower buds were fixed with Carnoy solution (3:1 ethanol 96\%: glacial acetic acid) for a minimum of 24 hours. Staining of chromosomes was performed with-alcoholic-hydrochloric carmine (Snow, 1963). The images were taken with a Leica DC 300 inserted in a Zeiss Axiophot microscope with Plan-apochromatic objective 63/1.4 and an increase of 1.25. Levan \& al. (1964) were followed for the morphological terminology and Stebbins (1938) for size terminology of the chromosomes.

\section{Systematic Treatment}

A morpho-geographical analysis of herbarium specimens of all relevant taxa associated with the $C$. lusitanica complex was performed, based on the following Herbaria: C, COI, FCO, G, HVR, LISE, LISU, MA, MGC, P, SALA, SALAF, SEV, W. All recognized species and most heterotypic synonyms have been typified. The initials of the provinces of Spain and Portugal which are cited in the description of each taxon follow those used in "Flora iberica".

\section{Results and discussion}

\section{Molecular Phylogeny}

The ITS region comprised 726 aligned nucleotide positions of which 469 were variable and 368 were parsimony informative. The first heuristic search found 101,914,528 equally parsimonious trees that were 2,480 steps long, with a consistency index of 0.353 , excluding uniformative characters, and a retention index of 0.748 . The second search did not find any other island of most-parsimonious trees, and trees from the first search were used to compute the strict consensus tree. The Bayesian analysis sampled 7,639 trees, which reached a stable likelihood value after burn-in 1,500 trees. The 50\% majority-rule consensus tree of all sampled trees showed a topology totally concordant with that recovered from the parsimony analysis. The Bayesian tree was better resolved than the parsimony-based tree, so only the Bayesian tree with both bootstrap and posterior probability support values for branches is shown in Fig. 1.

Topology within the ITS tree is consistent with results obtained in previous phylogenetic studies of the genus Campanula and allies (Eddie \& al., 2003; Park \& al., 2006; Roquet \& al., 2008, 2009; Cellinese \& al., 2009; Haberle \& al., 2009; Stefanović \& Lakušić, 2009). These show that the genus is paraphyletic and divided into two major clades, the 'Campanula s.str.' clade and the 'Rapunculus' clade, plus two small clades: the 'Musschia' clade (99\% bootstrap support, BS; $100 \%$ posterior probability support, PPS), that includes Musschia Dumort., Gadellia Schulkina, Campanula peregrina and Campanula primulifolia; and the 'Platycodon' clade (79\%BS; 100\%PPS), that includes Codonopsis Wall., Cyananthus Wall., Canarina L. and Leptocodon Hook. The genus Jasione L. is sister to Campanula s. 1. The 'Campanula s. str.' clade has good support $(72 \% \mathrm{BS} ; 100 \% \mathrm{PPS})$ although it

Table 1. Chromosome numbers for annual species of the Campanula luisitanica complex in the W Mediterranean area. Origin of material, gametic $(n)$ or somatic $(2 n)$ chromosome number of and authors who have studied the different annual species in this complex.

\begin{tabular}{|c|c|c|c|c|}
\hline Taxa & Studied material & $n$ & $2 n$ & Authors \\
\hline C. Iusitanica & $\begin{array}{c}\text { Rivadavia (Orense, Spain) } \\
\text { Serra de Lousã (Beira Litoral, Portugal) }\end{array}$ & 9 & $\begin{array}{l}18 \\
18\end{array}$ & $\begin{array}{l}\text { In this work } \\
\text { Fernandes (1962) }\end{array}$ \\
\hline C. matritensis & $\begin{array}{l}\text { Hervás (Cáceres, Spain) } \\
\text { Hinojos (Huelva, Spain) } \\
\text { Coimbra (Beira Litoral) }\end{array}$ & 9 & $\begin{array}{l}18 \\
18\end{array}$ & $\begin{array}{l}\text { Fernández et al. (2001) (as C. lusitanica) } \\
\text { In this work } \\
\text { Larsen (1954) (as C. loefingii) }\end{array}$ \\
\hline C. cabezudoi & Venta de Zafarraya (Granada, Spain) & & 20 & In this work \\
\hline C. specularioides & $\begin{array}{c}\text { Ubrique (Cádiz, Spain) } \\
\text { Benaocaz (Cádiz, Spain) } \\
\text { Montejaque (Málaga, Spain) }\end{array}$ & $\begin{array}{l}10 \\
10\end{array}$ & 20 & $\begin{array}{l}\text { García-Martín \& Silvestre (1985) } \\
\text { Gallego (1986) } \\
\text { In this work }\end{array}$ \\
\hline C. transtagana & $\begin{array}{c}\text { Valverde (Huelva, Spain) } \\
\text { Vila Velha de Rodão (Beira Baixa, Portugal) } \\
\text { Don Benito (Badajoz, Spain) }\end{array}$ & $\begin{array}{l}10 \\
10\end{array}$ & $\begin{array}{l}20 \\
20\end{array}$ & $\begin{array}{l}\text { In this work } \\
\text { Fernandes (1962) } \\
\text { Gallego (1986) (as C. lusitanica subsp. transtagana) }\end{array}$ \\
\hline C. broussonetiana & Jbel Tazzeka (Taza, Morocco) & & 20 & In this work \\
\hline C. decumbens & $\begin{array}{l}\text { Benaoján (Málaga, Spain) } \\
\text { Villamartín (Cádiz, Spain) }\end{array}$ & $\begin{array}{l}16 \\
16\end{array}$ & & $\begin{array}{l}\text { In this work } \\
\text { In this work }\end{array}$ \\
\hline C. dieckii & Alfarnate (Málaga, Spain) & & 28 & In this work \\
\hline
\end{tabular}




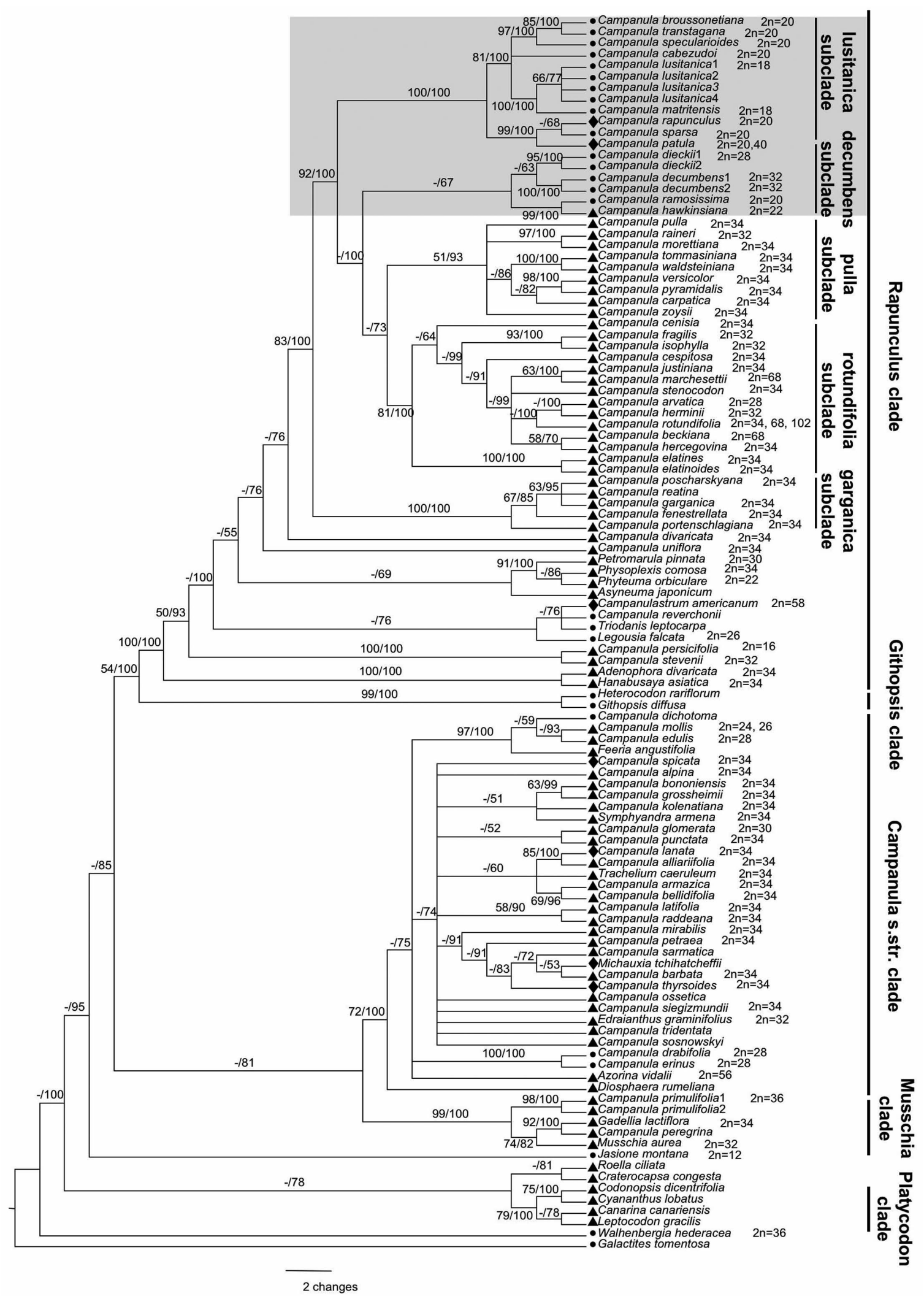

Fig. 1. Bayesian 50\% MR concensus tree topology of Campanulaceae ITS. Bootstrap and posterior probability values are indicated on corresponding branches. Symbols indicate the habit of the species: $\bullet$, annual; $\bullet$, biennial; $\boldsymbol{\Delta}$, perennial. The two sections that are the focus of this article are marked in gray. The chromosome numbers shown for the species that are not are specified in the text, derive from indices of plant chromosome number (Castroviejo, S. \& Valdés-Bermejo, E. (eds.). 1991. Archivos de Flora iberica I: números cromosomáticos de plantas vasculares ibéricas. CSIC. Madrid; Index to plant chromosome numbers. Monographs in Systematic Botany from the Missouri Botanical Garden [www.tropicos. org]; Moore, D.M. 1982. Flora Europaea. Checklist and chromosome index. Cambridge University press). 
showed little internal resolution. This clade includes species of Campanula subgenera Campanula and Roucela and the genera Diosphaera Buser, Azorina Watson, Edraianthus A. DC., Michauxia L'Hér., Trachelium L., Symphyandra A. DC., and Feeria Buser. The two genera Heterocodon Nutt. and Githopsis Nutt. form a small clade, (the 'Githopsis' clade, 99\%BS; 100\%PPS) that appears between the 'Campanula s. str.' and 'Rapunculus' clades.

The 'Rapunculus' clade forms a monophyletic and strongly supported group (100\%,BS; 100\%PPS), and as with the 'Campanula s. str.' clade, it includes taxa treated as separate genera [Hanabusaya Nakai, Adenophora Fisch., Legousia Durande, Triodanis Rafin., Campanulastrum Small, Asyneuma Griseb. \& Schenk, Pbyteuma L., Physoplexis (Endl.) Schur., Petromarula R. Hedw.] in addition to many species of Campanula. It comprises five principal well-resolved subclades: one subclade (100\% BS; $100 \% \mathrm{PPS}$ ) corresponds to the 'garganica' subclade of Park \& al. (2006); two subclades, 'rotundifolia' and 'pulla' subclade ( $81 \%$ BS; $100 \%$ PPS and 51\%BS; $93 \%$ PPS) include the isophyllous and heterophyllous species of Park \& al. (2006); And the other two subclades both include elements of the Campanula lusitanica complex of Cano-Maqueda \& al. (2008) which we have called the 'decumbens' subclade and the 'lusitanica' subclade.

The 'decumbens' subclade (67\%PPS) is formed by C. ramosissima and C. hawkinsiana Hausskn. \& Heldr., that are sister to $C$. decumbens and $C$. dieckii Lange. The 'lusitanica' subclade (100\% BS; $100 \%$ PPS) corresponds to the 'lusitanica' lineage of Cano-Maqueda \& al. (2008). In this subclade, C. patula, C. sparsa and C. rapunculus L. are sister to C. matritensis A. DC., C. lusitanica s. s., C. cabezudoi CanoMaqueda \& Talavera, C. specularioides Coss., C. transtagana R. Fern. and C. broussonetiana Schult. The four samples of $C$. lusitanica s.str. (from three different populations, see Appendix I) collapse into a moderately supported subclade $(66 \% \mathrm{BS} ; 77 \% \mathrm{PPS})$ and they appear as sister to C. matritensis in a well supported clade $(100 \%$ BS; $100 \%$ PPS). Moreover, C. lusitanica s.str. presents morphological differences with C. matritensis, and it has a more restricted geographical distribution than the latter (see systematic treatment), so we have treated these two as separate species.

\section{Karyological study}

All species of 'lusitanica' subclade have $2 n=20$ or $n=10$ chromosomes, except C. matritensis and $C$. lusitanica with $2 n=18$ or $n=9$. The taxa of 'decumbens' subclade, $C$. decumbens and $C$. dieckii, have $2 n$
$=32$ or $n=16$ and $2 n=28$ chromosomes, respectively (Table 1). All species studied have small or moderately small chromosomes $(1.2-4.1 \mu \mathrm{m})$, with the centromere located in the middle or submid region (Fig. 2). In C. specularioides, one pair of chromosomes with the centromere in the submiddle region has a satellite on the short arm. Chromosomes form bivalents in the meiotic metaphase.

The basic number found in annual species of the 'lusitanica' subclade in the W Mediterranean, $x=10$, coincides with that found in other species of this subclade: C. rapunculus, C. patula and C. sparsa (Larsen, 1956; Contandriopoulos, 1966). The basic number $x=9$ found in C. lusitanica and C. matritensis can be considered as aneuploid of $x=10$. The base number $n=10$ is extremely rare in Campanulaceae, and has only been previously reported for C. ramosissima (Podlech \& Damboldt, 1964). The chromosome number found in $C$. dieckii, $2 n=28$, has been previously found in the subgenus Roucela sensu Damboldt, in C. erinus (Gallego, 1986) and C. drabifolia Sibth. \& Sm. (Contandriopoulos, 1964a), and in C. edulis Forssk. (according to Goldblatt \& Johnson, 1990), all species of 'Campanula s. str.' clade, and also in C. arvatica Lag. (Podlech \& Damboldt, 1964), a species of 'Rapunculus' clade (Fig. 1). The chromosome number found in $C$. decumbens, $2 n=32$, is also found in some species of the 'Rapunculus' clade, [C. raineri Perpenti (Podlech \& Damboldt, 1964), C. fragilis Cyr. (Damboldt, 1965), C. isopbylla Moertti (Merxmüller \& Damboldt, 1962), C. herminii Hoffmans. \& Link (Damboldt \& Podlech, 1964), and C. stevenii Bieb. (according to Goldblatt, 1985), and Edraianthus graminifolius (L.) A. DC. (Contandriopoulos, 1964b), a taxon of the 'Campanula s. str.' clade, and Musschia aurea Dumort. (according to Goldblatt \& Johnson, 1994), a taxon of 'Musschia' clade]. Since $2 n=34$ is the most frequent number in Campanulaceae, it seems likely that $2 n=32$ is an aneuploid of $2 n=34$ (see Fig. 1).

\section{Systematic treatment}

After reviewing all specimens we found that the different species can be separated in two groups on basis on the morphology of the style and stigma: one formed by $C$. decumbens and $C$. dieckii, with the style glabrous and with three stigmas with arms straight and erect or erect-patent; and another formed by all other species, with the style hairy in the upper half, and a trifid stigma, with the stigmatic arms curved or circinate. These two groups are consistent with the molecular results and karyology, so that they are probably natural, and the most appropriate taxonomic treatment is to recognise them as sections. The second 

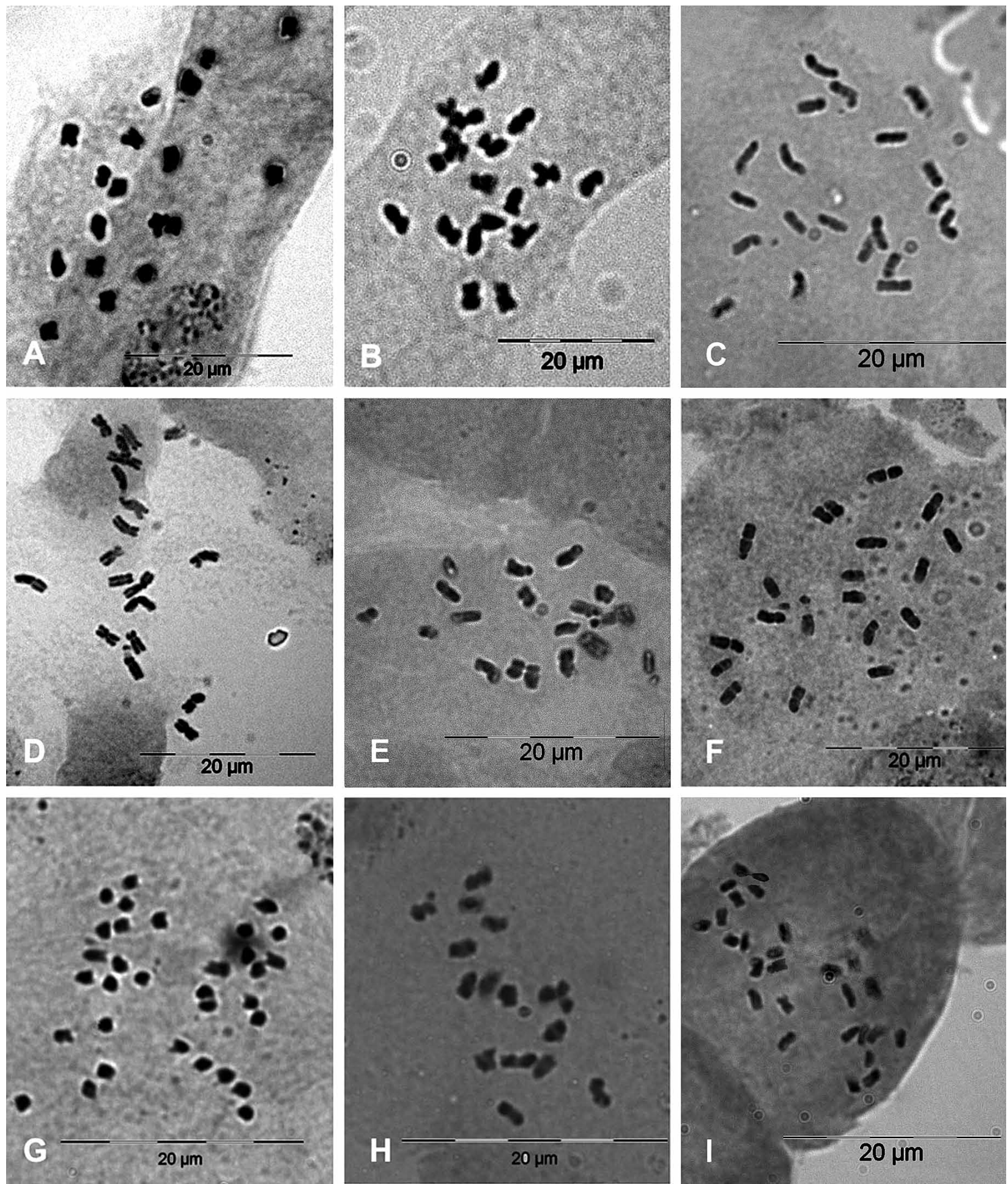

Fig. 2. Karyology of Campanula species. A-F and I, mitotic metaphase; G, meiotic anaphase I; H, meiotic metaphase I. A, C. IUsitanica, $2 n=18$ (Rivadavia, Orense, Spain, SEV 218947); B, C. matritensis, $2 n=18$ (Hinojos, Huelva, Spain, SEV 216214); C, C. cabezudoi, $2 n=20$ (Venta de Zafarraya, Granada, Spain, SEV 218873); D, C. specularioides, $2 n=20$ (Montejaque, Málaga, Spain, SEV 216210); E, C. transtagana, $2 n=20$ (Valverde del Camino, Huelva, Spain, SEV 216212); F, C. broussonetiana, $2 n=20$ (Jbel Tazzeka, Taza, Morocco, SEV 216476); G, C. decumbens, $n=16$ (Benaoján, Málaga, Spain, SEV 218875); H, C. decumbens, $n=16$ (Villamartín, Cádiz, Spain, SEV 256653); I, C. dieckii, $2 n=28$ (Alfarnate, Málaga, Spain, SEV 256652). The scale bar $=20 \mu \mathrm{m}$. 
group, which includes Campanula rapunculus L., would constitute the sect. Rapunculus. The first group would establish a new section, sect. Decumbentes which is formally described below. Within these sections, the most significant characters are: the shape of the corolla (campanulate or infundibuliform), middle cauline leaves (petiolate or sessile), capsule morphology (obpyramidal, subglobose or subovoid), and ovary indumentum (setose, glabrous or papillose).

We used this combination of characters to create a key for the identification of all annual species of the C. lusitanica complex in the Western Mediterranean.

\section{KEY TO THE SPECIES}

1. Style 2.1-4(4.8) mm, glabrous, with three stigmas; stigmas straight, erect or erect-patent ..................................... 2

1. Style (4.5)5-14 mm, hairy in the upper half, with one trifid stigma; stigmatic branches curved or circinate, patent ....... 3

2. Stems glabrous or with few antrorse hairs, often scabrid near the flowers; upper cauline leaves cuneate or shortly petiolate; corolla $12-21 \mathrm{~mm}$

7. C. decumbens

2. Stems densely pubescent with setose hairs, sometimes glabrescent towards the apex; upper cauline leaves sessile, subauriculate; corolla (6.6)8-13.7 mm ............ 8. C. dieckii

3. Corolla infundibuliform, with three purple nerves in each lobe; middle cauline leaves petiolate; plant decumbent ..... 4

3. Corolla campanulate, without purple nerves in the lobes; middle cauline leaves sessile or petiolate; plant erect or decumbent

4. Capsule 2-3 × 3-4.5 mm, subspherical, generally glabrous, dehiscing by 3 pores of middle position, with 10 subwinged nerves; stems and leaves glabrous or glabrescent; calyx-teeth oblanceolate

4. C. specularioides

4. Capsule 2.1-5.9 × 2.2-5 mm, ovoid or subspherical, usually densely hairy, dehiscing by three apical pores, with $10 \pm$ acute but non-winged nerves; stems and leaves pubescent; calyx-teeth lanceolate or linear

3. C. cabezudoi

5. Middle cauline leaves petiolate and elliptic or sessile and cuneate

5. Middle cauline leaves sessile, ovate-lanceolate or lanceolate .................................................................. 7

6. Upper half of the stem and leaves with short hairs $0.1-0.3$ $\mathrm{mm}$; middle cauline leaves with petiole 0.2-4.5 mm

5. C. transtagana

6. Upper half of the stem and leaves with long hairs, the longest 0.4-2 mm, or rarely glabrous; middle cauline leaves sessile and cuneate or with petiole up to $2 \mathrm{~mm}$ and rounded at the base

6. C. broussonetiana

7. Middle cauline leaves ovate-lanceolate, subauriculate, densely patent-hairy, with long hairs up to 0.8-1.1 mm; capsule subovoid, with 10 subwinged acute nerves ....... 1. C. lusitanica

7. Middle cauline leaves lanceolate, glabrous or with sparse hairs 0.1-0.5 mm; capsule obpyramidal, with 10 very wide nerves, like flat ribs

2. C. matritensis

A. Sect. Rapunculus Boiss., Fl. Orient. 3: 895. 1875

Campanula subgen. Rapunculus (Boiss.) Kharadze in Zametki Sist. Geogr. Rast. Tiflis 28: 100. 1970

Type: C. rapunculus $\mathrm{L}$.
Annual or biennial plants. Lower leaves oblanceolate or spathulate, petiolate. Without calycine appendages. Corolla campanulate or infundibuliform. Stamens with white or blue anthers. Style with numerous pollen collecting hairs on the upper half, with a trifid stigma; stigmatic arms curved or circinate, patent, white or blue, with numerous pollen collecting hairs on the abaxial surface glabrous, and receptive on the adaxial surface. Capsule subspherical, ovoid or obpyramidal, dehiscing by three apical or middle position pores. $x=9,10$ (see karyology).

Observations: This section includes: Campanula rapunculus and C. patula of the Mediterranean region; C. lusitanica, C. matritensis, C. cabezudoi, C. specularioides, C. transtagana and C. broussonetiana from the W Mediterranean; and C. sparsa and possibly C. spatulata Sibth. \& Sm. of the E Mediterranean. The section is monophyletic (see lusitanica clade in Fig. 1).

Experimental manual crosses showed that all annual species of the W Mediterranean had hybridization barriers at different levels: (1)- fruits were not produced, (2)- seeds do no germinated, (3)- germinated seeds formed chlorotic seedlings which did not survive and (4)- no chlorotic seedlings survived after the cotyledon state but they did not complete their development (Cano-Maqueda unpublished studies).

1. Campanula lusitanica L. in Loefl., Iter Hispan.: 111, 126. 1758

Campanula loeflingii Brot., Phytogr. Lusitan. Select. Fasc. I: 20. 1800, nom. superfl. C. patula var. lusitanica (L.) Pau in Bol. Soc. Iber. Ci. Nat. 20: 181. 1921. Ind. loc.: "Habitat in Lusitania ad Porto in collibus \& muris". Type: Portugal. Porto, June 1917, Mário de Castro s.n. [Sennen, Pl. Espagne n. ${ }^{\circ}$ 3305] (neotype, here desinated, G 104248!, Fig. 3; see observations).

C. duriaei Boiss., Voy. Bot. Espagne 2: 402. 1839. Ind. loc.: "Hab. In Hispaniâ circà Olyssiponem (L. Et Hoffm.), Hispaniâ septentr. In Asturiis (Durieu)”. Type: Spain. Asturias, Cangas de Tineo, 25 July 1835, Durieu s.n. [Plant. Select. Hispano-Lusit. Sect. $1^{a}$ n. $\left.{ }^{\circ} 280\right]$ (lectotype, here designated, G 104093!; see observations).

C. loeflingii var. occidentalis Lange in Vidensk. Meddel. Dansk Naturhist. Foren. Kjøbenhavn 1861: 107, 108. 1862. Ind. loc.: "In Gallecia frequent!". Type: Spain. Galicia [not found in the Lange herbarium $(C)]$.

C. lusitanica var. puberula C. Vicioso in Anales Jard. Bot. Madrid 6: 78. 1946. Ind. loc.: "Hab. Ribadelago (Zamora)”. Type: Spain. Zamora, Ribaldelago, 
19 July 1945, C. Vicioso s.n. (lectotype, here designated, MA 121525!; see observations).

\section{Illustrations: Fig. 4 A, B.}

Herb $16-50 \mathrm{~cm}$, annual, erect, branched from the base, rarely in the upper half, densely pubescent, not brittle. Stems angled, branched or simple, densely pubescent, rarely glabrescent in the uppermost portion, with short and long hairs, the longest $0.5-1.5 \mathrm{~mm}$. Leaves somewhat coriaceous, entire, crenulate or toothed; middle cauline leaves 5-30 × 3.1-10.9 mm, sessile, ovate-lanceolate, subauriculate, entire or toothed, densely pubescent, \pm long hairs, the longest 0.8-1.1 mm; upper cauline leaves 4-14.5 × 0.5-4.4 mm, sessile, lanceolate, truncate or somewhat auriculate, pubescent, with hairs up to $0.9 \mathrm{~mm}$. Inflorescence paniculate, highly branched, lax or dense and spiciform. Flowers pedicellate or subsessile; pedicel (3)7$16 \mathrm{~mm}$, glabrous or with hairs $0.1-0.2 \mathrm{~mm}$. Calyxteeth 3.7-9(17.3) $\times$ 0.4-0.6(1.3) $\mathrm{mm}$, linear, recurved in the female phase flower. Corolla (8.2)10-18.9 mm, campanulate, with tube longer or shorter than lobes; tube 3.5-9.7 $\mathrm{mm}$, blue at the apex, white at the base; lobes 3.7-9.2 × 2.2-6.1 mm, elliptic-lanceolate, not re-

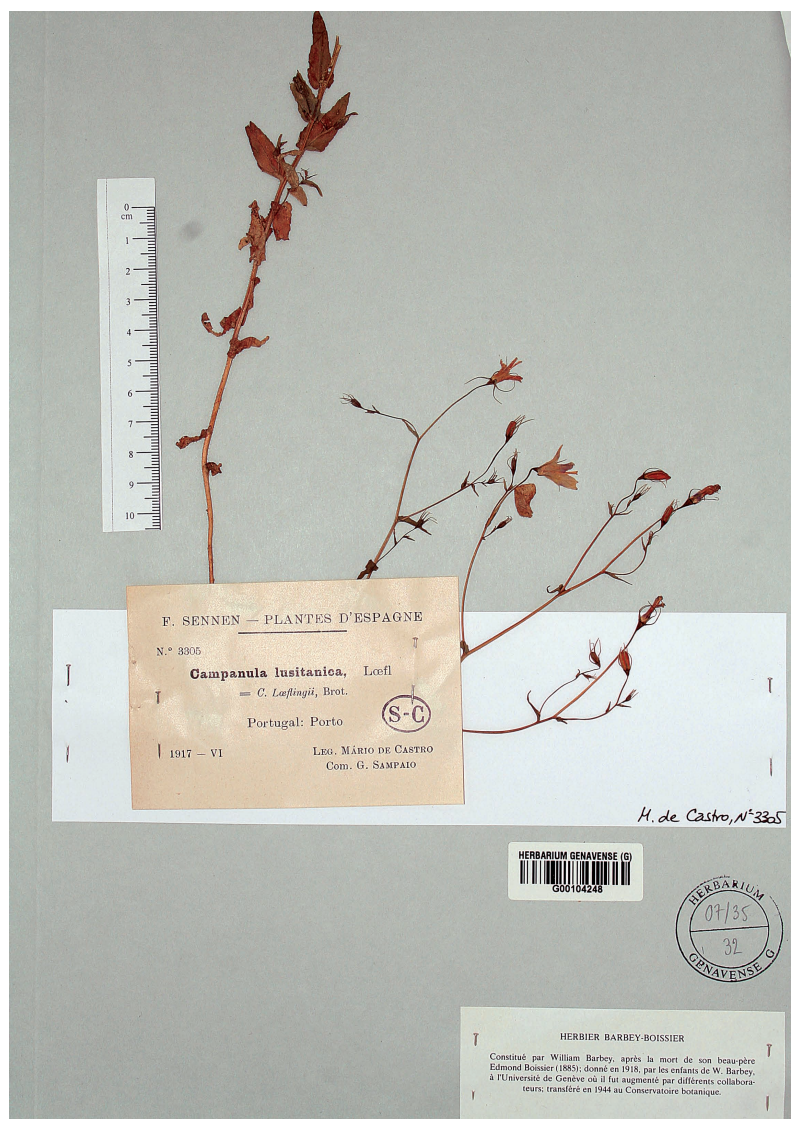

Fig. 3. Neotype of Campanula lusitanica (G 104248). flexed in the female phase flower, blue. Stamens with enlarged base of 0.6-1 × 0.4-0.5 mm; filaments 0.2-0.5 $\mathrm{mm}$; anthers (1.5)3-5 mm, whitish. Ovary papillose or with setose hairs of 0.1-0.2 mm; style 7.5-11.8 mm, hairy in the upper half; stigma trifid, with stigmatic branches of $0.3-1.2(2.8) \mathrm{mm}$, patent, circinate, white. Capsule (2.4)4-6 × (2.5)3-4 mm, subovoid, longer than wide, papillose, rarely with some setose hairs 0.1$0.2 \mathrm{~mm}$, with 10 subwinged and acute nerves, dehiscing by three apical pores. Seeds $0.3-0.5 \times 0.2-0.3 \mathrm{~mm}$, ellipsoid, shining, yellowish to brown. $2 n=18 ; n=9$.

Habitat, phenology and distribution: Wet grasslands on generally acid substrates, sometimes draining and river banks; $15-1800 \mathrm{~m}$. (V)VI-VIII. • Endemic to the NW of the Iberian Peninsula, common in Galicia and $\mathrm{N}$ Portugal, and also occurring in S Portugal, Monchique (Fig. 5). Portugal: Ag BA BL DL Mi TM. Spain: C Le Lu O Or Po Sa Za.

Observations: López-González (in litere) has commented apropos the type of Campanula lusitanica: "Al parecer, Linneo no conoció nunca Campanula lusitanica, porque dicha planta no figura en la lista de materiales de Loefling enviados a Linneo en 1752 (Spanish list), pero en una carta de Loefling a Linneo, fechada el 7.VII.1751 y escrita en Oporto, le indicó que «Campanula caule angulato, ramoso, vago, calice corollae tubulosae aequali», la que Linneo denominaría C. lusitanica, habita aquí [Porto] en los caminos y en las tapias. Tampoco figura esta planta ni como Campanula lusitanica ni como «Campanula caule angulato...» en la lista del herbario de Loefling que redactó un capellán sueco, probablemente porque en esta lista solo figuraban las plantas identificadas, y «Campanula caule anguloso...» aún no tenía nombre. Es en el herbario de Loefling donde se podría encontrar la planta como Campanula sp., pero este herbario lo perdió Casimiro Gómez Ortega, que al parecer, según cuenta en una carta, lo prestó a un botánico francés y éste no lo devolvió".

Since it was impossible to find the type material of C. lusitanica in the different Linnean herbaria, the election of a neotype has been proposed. The plants in question have long and patent cauline hairs, and so do not correspond to the plant described by Loefling, who indicates "Caulis ... leviter hispidus pilis pallidis, brevissimis". The shape of the cauline leaves, ovateoblong or ovate-lanceolate, are however like those of the plants described by Loefling, who indicates "Folia caulina \& subramorum ovato-oblonga, subglabra, sessilia, subserrata, alterna; ramorum superiora ovatolanceolata, vix serrata" and the whitish colour at the base of the corolla tube is also consistent with the description of Loefling: "Cor. caeruleis, tubulo infimo 
brevísimo albo". In accordance with these characteristics, we have chosen the plants from Porto as neotype of Campanula lusitanica.

Brotero (1800: 20-21) gave a new name, C. loeflingii, to the plant collected in Porto by Loefling, but this name is illegitimate, since Linneus had named it as C. lusitanica in the work of Loefling. Brotero (1804: 287) subsequently not only described the Loefling plant, but also included characters from another species later described by Alphonse De Candolle
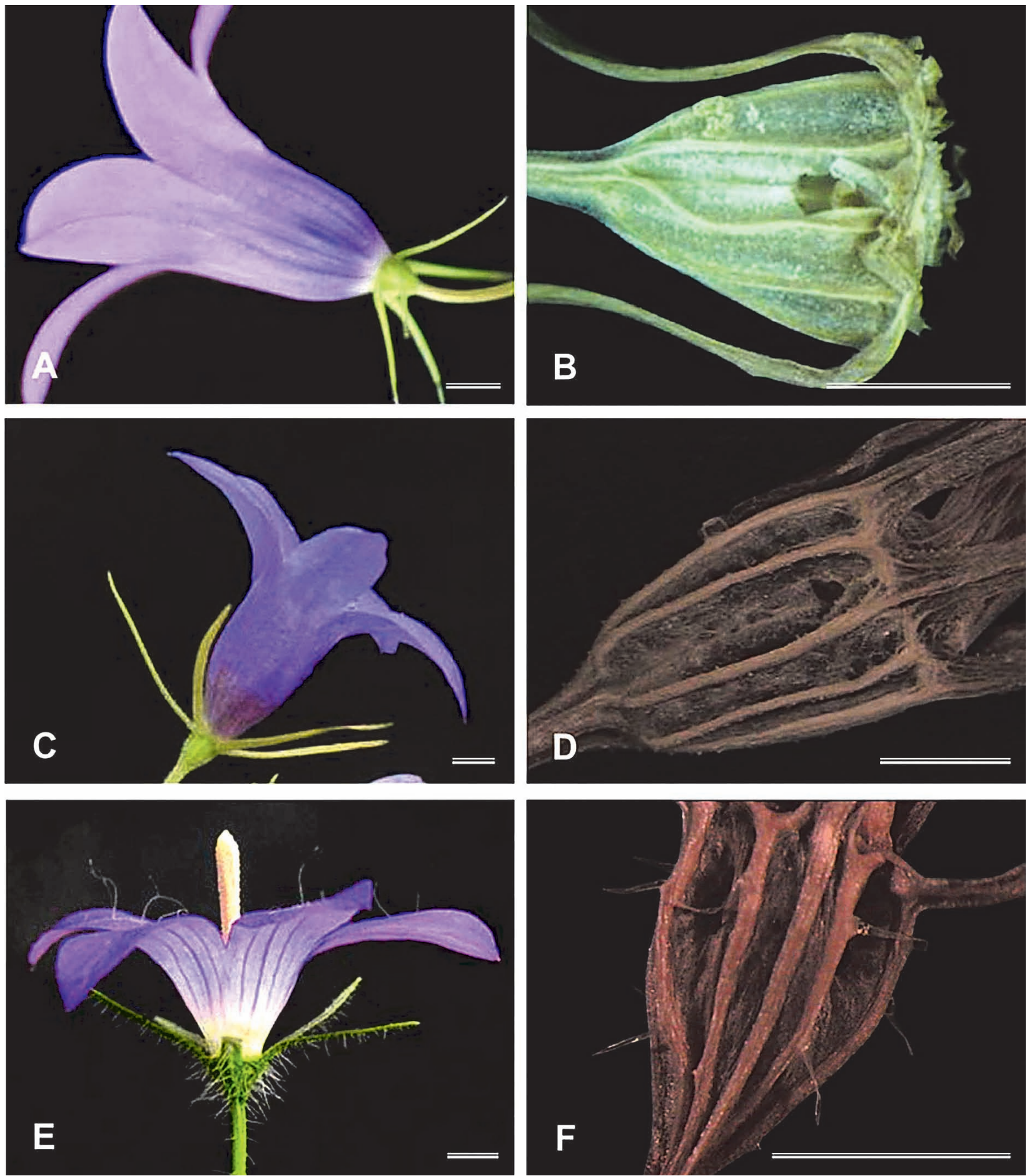

Fig. 4. Flowers and fruits of Campanula species. A, B, C. lusitanica (Rivadavia, Orense, Spain, SEV 218947); C, D, C. matritensis (Hinojos, Huelva, Spain, SEV 261264); E, F, C. cabezudoi (Venta de Zafarraya, Granada, Spain, SEV 218873). The scale bar $=3 \mathrm{~mm}$. 
(1830) as C. matritensis. Indeed, the illustration that appears in his "Phytographia Lusitanieae Selectior" (Brotero, 1816, tab. 18) corresponds more closely to C. matritensis than to C. lusitanica. Hoffmannsegg \& Link (1820-1824: 14) also provided a brief description of $C$. loeflingii, but like Brotero, they could be referring to both $C$. lusitanica and $C$. matritensis.

Boissier (1839) described C. duriaei based on the characters of plants collected by Durieu in Cangas de Tineo (Asturias) distributed as the Exiccata No 280 in 1835. In the herbarium at Geneva there are three sheets of this collection (G 104093, G 104120 y $G$ 104116). The first (G 104093) consists of 4 complete plants mounted on two sheets, and comes from the Boissier Herbarium. One of the sheets contains two plants of $30 \mathrm{~cm}$ and $22 \mathrm{~cm}$ respectively, and a Boissier handwritten label indicating "C. Duriaei/284". We have chosen as lectotype the $30 \mathrm{~cm}$ plant because it is the closest to the description; the other plant, of 22 $\mathrm{cm}$, is an isolectotype. The other sheet also contains two plants without any annotation by Boissier; they are also likely isolectotypes. The other two sheets $(G$
104120 and G 104116) are from the herbarium of Moïse-Etienne Moricand which were incorporated into the herbarium of the Conservatoire et Jardín Botanique de Genève in 1908; the plants contained in them, which were not seen by Boissier, are not part of the type material. Boissier was the first author to clearly describe the characteristic hairs of the Asturian plants: "Toute la plante est d'une consistance délicate et couverte de poils long et étalés, tandis que la $C$. loeflingii est u glabre ou hérissée de poils rudes et courts". Boissier's concept of $C$. loeflingii was very wide, since he included in this species most of the taxa of this group which had been collected by him in southern Spain or that he had seen in the Fouche or De Candolle herbaria. We identify Fouche herbarium plants as C. decumbens subsp. baetica Cano-Maqueda $\&$ Talavera and those in the De Candolle herbarium as $C$. broussonetiana, and the plants that he collected in Southern Spain as C. matritensis and C. dieckii (see these species below).

The type material of $C$. lusitanica var. puberula consists of three plants mounted on the same sheet. We

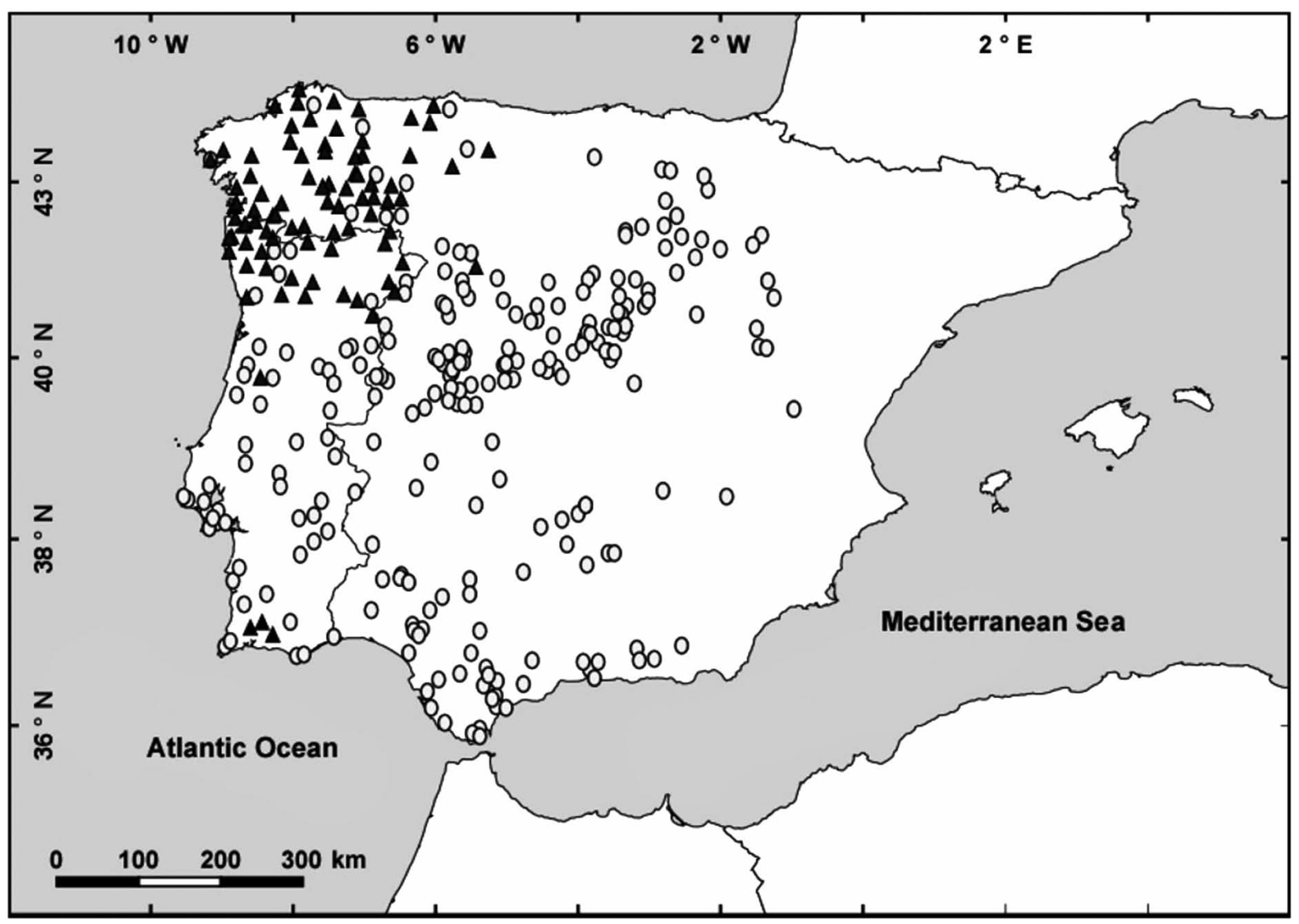

Fig. 5. Distribution map of Campanula lusitanica ( $\mathbf{\Delta})$ and C. matritensis (O). 
have chosen as lectotype the larger specimen mounted on the left, and the other two plants are isolectotypes

Campanula lusitanica is very similar in the indumentum and the branching to C. broussonetiana, but C. lusitanica has $2 n=18$ chromosomes, as does C. matritensis, while $C$. broussonetiana has $2 n=20$ chromosomes, as do almost all species of sect. Rapunculus. The ITS phylogenetic tree shows that $C$. lusitanica and C. matritensis are sister species (see Fig. 1).

\section{Selected specimens}

PORTUGAL. Algarve: Serra de Monchique, entre Monchique e Alferce, Rouxinel, 27-VI-1978, M. Beliz (MA 270314); ibidem, de Pesos a Monchique, 24-VII-2009, S. E M. Talavera (SEV 248712). Beira Alta: Figueira de Castelo Rodrigo, Escalhão, 26-V-1996, M. Santos E M. Sequeira (HVR 8048). Serra da Estrela, without date, Romariz (LISU 2054); ibidem, Garganta de Loriga, VIII-1912, A.A. Silva Martins (LISU 36386). Vizeu, Santa Comba Dão, Pinheiro de Azer, arredores da ponte sobre a barragem, 20-VI-1982, $A$. Marques (MA 377387). Beira Litoral: Coimbra, Penacova, Oliveira do Mondego, 13-V-1982, A. Marques (MA 391392). Douro Litoral: entre Oliveira y San Joao de Madeira, dirección Oporto, 24-VI1986, J.A. Devesa E al. (SEV 161720). Porto, Castelo prox. Souto de Lafões, 27-V-1940, recolector ilegible (LISU 36362). Minho: Ancora, VI-1886, A.R. da Cunba (LISU 36367). Areosa, VI-1886, A.R. da Cunba (LISU 36404). Barcelos, VI-1886, A.R. da Cunba (LISU 36368). Caldas do Gerez, IX-1882, M.L. Enriques (COI). Caminha, Retorta, VI-1885, A.R. da Cunba (LISU 36379). Celorico de Basto, VI-1884, A.R. da Cunha (LISU 36380). Entre Ponte de Barca y Vila Verde, 27-VI-1982, M.J. Gallego \& al. (SEV 161716). Fafe, Lameira, 7-VIII-1977, M. Beliz (MA 270317). Gondarem, VI-1885, A.R. da Cunba (LISU 36377). Melgaço, VI-1894, A. Moller (COI). Monção, Lavandeira, VI-1885, A.R. da Cunba (COI, LISU 36407). Ponte de Lima, VII-1894, M. Rodr. Maraes (COI). Povoa de Lanhoso, VI-1920, J. Sampaio (MA 121499). Senhora da Peneda, Serra do Soajo, VII-1890, A. Moller (COI). Serra Amarela, Mata do Cabril, Carvalhal do Sono, 8-VIII-1977, M. Beliz \& J. Guerrero (MA 270316), Serra da Peneda, 880m, VI-1956, R. Bentos (LISE 48610). Serra do Gerez, 2-VII-1948, Romariz (LISU 922). Soajo, Serra do Soajo, VI-1890, A. Moller (COI). Vanlença, Olivar de Santa Barbara, VI-1885, A.R. da Cunba (LISU 36403). Veiga de Chaves, V-1910, F. Mendez E al. (LISU 36389). Veiga de Ganfei, VI-1885, A.R. da Cunha (LISU 36392). Vila Nova da Cerveira, VI1885, A.R. da Cunba (LISU 36402). Trás-os-Montes: arredores de Bragança, VI-1882, P.F.M. Var (COI). Bragança, 1877, Pereira Coutinho (LISU 36358). Entre Montalegre e Chaves, Sapiãos, VI1910, R. Palbinha E al. (LISU 36385). Estação do Pocinho, VI1915, Mendes E Palhinha (LISU 36387). Mogadouro, a montante da pte. de Ramondes, na margem dta. do rio Sabor., 18-V-1997, $A$. Castro \& Tjarda De Koe (HVR 9475). Montalegre, 21-VII-1959, M. da Silva (G 104096). Montinho, Seixas, VI-1885, A.R. da Cunba (LISU 36401). Santa Marta de Penaguião, Veiga, Aldeia do Bertelo, 25-VI-1993, A. Coelho Costa \& A.L. Crespí, A (HVR 10177). Vila Nova de Foz Côam, margem do Douro (esquerda) a jusante da Foz do Sabor, frente à Ilha, 30-IV-1995, M. Sequeira (HVR 5937). Vila Real Coêdo, 10-VII-1981, A. Além (HVR 3902, SANT 39046). Vimioso, VI-1888, G. Mariz (COI).

SPAIN. Asturias: Cangas de Tineo, 2-VI-1864, E. Bourgeau, in E. Bourgeau, Pl. d' Espagne 1864: n 2657 (G 104119, G 104118, MA 121552, MA 152778). Corneliana, 16-VIII-1868, E. Boissier (G 104109). Pravia, without date, La Gasca (MA 121844). Taramundi, VII-1979, T.E. Diaz (MGC 14104). Asturias, VII-VIII-
1878, E. Boissier (G 104121, G 104117). La Coruña: Aranga, 30VI-1967, J. Dalda (SALA 35816). Cariño, Landoi, 4-VIII-1994, X. Soñora (SANT 31851). Carnota, 1-VI-1996, R.I. Louzán (FCO 24813, MA 581374, SANT 35758). Cuenca del río Deo, 1966-1968, I. Dalda (SANT 55699). Ferrol, 27-VI-1994, X. Soñora (SANT 29263). Mazaricos, 25-VI-1995, R.I. Louzán (SANT 35746). Santiago de Compostela, Pontepedriña, VI-1995, Rodríguez-Hergueta (SANT 42394). Sobrado, 24-VII-1882, J. Lange (G 104115). Somozas, 17-VII-1994, X. Soñora (SANT 31883). León: La Baña, Sierra de Cabrera, camino del Lago, 10-VII-1981, Lansac E Nieto (MA 317215, MA 317216, MA 317216). Palacios del Sil, Salentinos, 27-VIII-1996, Martín-Blanco (MA 597090). Ponferrada, Villanueva de Valdueza, VIII-1995, Rodríguez-Hergueta (SANT 42467). Riocastrillo de Ordás, 22-VI-1997, C. J. Martín-Blanco (MA 612392). Sobrado, Castropetre, 30-V-1990, J. Amigo EJ. Giménez (SANT 26556). Valle del Bierzo, VI-1905, M. Gandoger (G 104142). Lugo: alrededores de la ciudad, 26-VI-1987, E. Carreira (MA 513456). Becerreá, El Cruzul, 18-VII-1989, S. Castroviejo E al. (MA 471686). Cabreira-Fonsagrada, VII-1957, E. Carreira (MA 204700). Cervantes, Correal, entre El Portelo y Piedrafita, 28-VI1994, M. A. Carrasco \& al. (MA 543383). Chantada, 18-VI-1988, M. Buján (SANT 25112). Entre Esperante y Carbedo, 5-VII-1979, J. Amigo \& al. (SANT 16230). Ferreiravella, 19-VI-1980, J. Amigo E al. (SANT 16229). Meiraos, 16-VII-1981, J. Amigo \& al. (SANT 16226). Monforte, 18-V-1991, J. Amigo \& M. Romero (SANT 25426). O Saviñao, Mourelos, 14-VII-1992, J. Amigo \& M. Romero (SANT 22471, MA 517178). Palas de Rey, 16-VI-1951, Seijas (SANT 6124). Piornedo, 23-VII-1952, Bellot E Casaseca (SANT 6783). Quiroga, Hermida, San Victorio, 18-VI-1988, M. Buján E M. I. Romero (MA 546783, SANT 25107). Riberas de Lea, 25-VII1956, E. Carreira (MA 201352). Sierra del Caurel, Seoane, 28VII-1992, E. Blanco (MA 564613). Tardad. Villalba, 30-VII-1951, M. Orosa (G 104101). Vilamelle, 6-VI-1990, M.I. Romero (MA 546757. SANT 26231). Orense: Carballeda, 10-VII-1984, S. Ortiz (SANT 16523). Chandreja de Queija, pr. Paradaseca, 24-VII-1974, S.I. Lainz (MA 345998). Corrainzas, 12-VIII-2000, J. De Jesús E al. (SANT 46020). Entre Sobradelo y Casayo, 15-VI-1958, Bellot E Casaseca (SANT 9940). Leboreiro, 13-VII-1958, F. Bellot \& B. Casaseca (MA 180705). Lobios, 9-VII-1993, I. Pulgar (SANT 56572). Río Lonia, 15-VII-2000, A.R. Romero E al. (SANT 45644). Río Sil, 15-VI-1958, Bellot E Casaseca (SANT 10066). Rivadavia, carretera a la Franqueirán, 24-VIII-2007, R. Pino (SEV 218947). Rubiá, Pardellán, Río Sil, 29-VI-1994, M.A. Carrasco E al. (MA 542966, SALA 115638). Serra do Invernadeiro, inter Rocín et Suacenza, 11-VII-1973, S. Castroviejo (MA 219730, MA 196712). Verín, 7-VI-1988, M. Buján E M. I. Romero (SANT 25110, SANT 25108). Pontevedra: Albeos, 14-VI-1988, M. Buján (SANT 25113). Cangas de Morrazo, 6-VIII-2007, S. Castroviejo (SEV 218948). Crecente, 24-V-1998, J. Amigo \& al. (SANT 39787). Cuntis, 9-VI2007, J. García Devesa (SANT 57381). Ermelo, Bueu, 15-VII-1970, S. Castroviejo (MA 196710). Meaño, 16-III-1988, M. Buján E M.I. Romero (SANT 25109). Porteliña, 16-VIII-1983, S. Sivestre (SEV 161714). Prado, 15-VII-1947, Vieiter (SANT 213). Salvaterra de Miño, 24-V-1998, J. Amigo E al. (SANT 39806). Salamanca: Aldeadavila, 22-IV-1977, F. Amich (SALA 15518). La Fregeneda, 30-IV1977, F. Amich (SALA 15519). Zamora: Montelarreina, 31-V-1987, R. García Ríos (SALA 54045). Ribadelago, 14-VI-1987, A. Roa \& P. García (MA 510330).

2. Campanula matritensis A. DC., Monogr. Campan.: 332.1830

C. lusitanica subsp. matritensis (A. DC.) Franco, Nova Fl. Portugal: 2, 569. 1984. C. patula var. matritensis (A. DC.) Pau in Bol. Soc. Iber. Ci. Nat.: 20, 181. 
1921. C. loeflingii var. matritensis (A. DC.) Lange in Vidensk. Meddel Dansk Naturhist. Foren. Kjøbenhavn 1861: 108. 1862. Ind. loc.: "Habitat in Hispania circa Matritum (Lagasc.!)". Type: Spain. Madrid, 1806, Lagasca s.n. (lectotype, here designated, G 138402! (G-DC.), Fig. 6; see observations).

Illustrations. Gallego (1987: 564, as C. lusitanica); Brotero (1816, tab 18, as C. loeflingii); Hoffmannsegg \& Link (1820, tab. 82, as C. loeflingii); Sáez \& Aldasoro (2001: 130, fig. 39b-h, as C. lusitanica subsp. lusitanica); Fig. 4 C, D.

Herb (6)10-55 cm, annual, erect, branched at the base or in the upper half, often laxly pubescent, not brittle. Stems angled, little branched, laxly pubescent in the lower half with setose hairs 0.1-0.3(0.5) $\mathrm{mm}$. Leaves not coriaceous, crenate, dentate or entire; middle cauline leaves 4.5-27 × 0.9-9.2 mm, sessile, lanceolate, entire or toothed, glabrous or laxly pubescent, with hairs 0.1-0.5 mm; upper cauline leaves $2-22 \times$ 4.5-5.8 mm, sessile, lanceolate, glabrous or with some hairs of 0.1-0.4 mm. Inflorescence laxly paniculate. Flowers pedicellate; pedicel $3.5-123 \mathrm{~mm}$, glabrous or with some hairs of 0.1-0.2 mm. Calyx-teeth (2.2)4-15 $\times 0.3-1(1.3) \mathrm{mm}$, linear, filiform. Corolla (8.8)11-26 $\mathrm{mm}$, campanulate, with the tube much longer or much shorter than the lobes; tube (4.2)7-15.3 mm, bluish; lobes (5.5)6-16 × 2-7 mm, ovate, blue. Stamens with enlarged base of 0.6-1 × 0.3-0.7 mm; filaments 0.4-0.6 mm; anthers (2)3-5 mm, white, rarely bluish. Ovary glabrous, papillose or with scattered hairs of 0.1-0.2 mm; style 5-14 mm, hairy in the upper half; stigma trifid, with stigmatic branches of 1-2(3.1) mm, patent, circinate at the end of the female phase of the flower, white. Capsule (2.5)4-9.2 × 2-5 mm, obpyramidal, much longer than wide, glabrous, papillose or with some setose hairs less than $0.1 \mathrm{~mm}$, with 10 very wide nerves like flat ribs, dehiscing by three apical pores. Seeds 0.4-0.6 $\times 0.2-0.3 \mathrm{~mm}$, ovoid, shining, yellowish to brown. $2 n=18 ; n=9$.

Habitat, phenology and distribution: Pine, cork oak and holm oak woodlands or their shrubby secondary communities, often on sandy substrates, but also on clay; 0-2200 m. V-VI(VII). • Endemic to the Iberian Peninsula. Distributed almost throughout the entire peninsula, but rare in limestone areas of $\mathrm{C}, \mathrm{E}$ and $\mathrm{N}$ of Spain, and absent in NE of Spain (Fig. 5). Portugal: AAl Ag BA BAl BB BL E Mi R TM. Spain: Ab Al Av $\mathrm{Ba} \mathrm{Bu} \mathrm{C}$ Ca Cc Co CR Cu Gr Gu H J Le Lo Lu M Ma O S Sa Se Sg So Te To Va Vi Z Za.

Observations: This species is very variable in size, flower size, indumentum and shape of the calyx, and indumentum and size of the capsules. The plants that live in very shady banks are usually delicate, have small flowers and, in general, asymmetric capsules due to lack of fertilization in one or two of the three locules, probably caused by deficient pollination. In contrast, plants living in sunny and humid areas are vigorous, highly branched, with large flowers and perfectly symmetrical obpyramidal capsules, with all locules full of seeds, denoting a very efficient fertilization. On shallow soils, in montane areas, plants are very small, slightly branched, with small flowers and sometimes with \pm ovoid and malformed capsules due to a deficient pollination, and these may be confused with C. transtagana or even with C. lusitanica.

The three plants of type material of $C$. matritensis (Fig. 6), about $15 \mathrm{~cm}$, attached to the label, have sessile cauline linear-lanceolate leaves, and obconical capsules. These agree with the characters described by

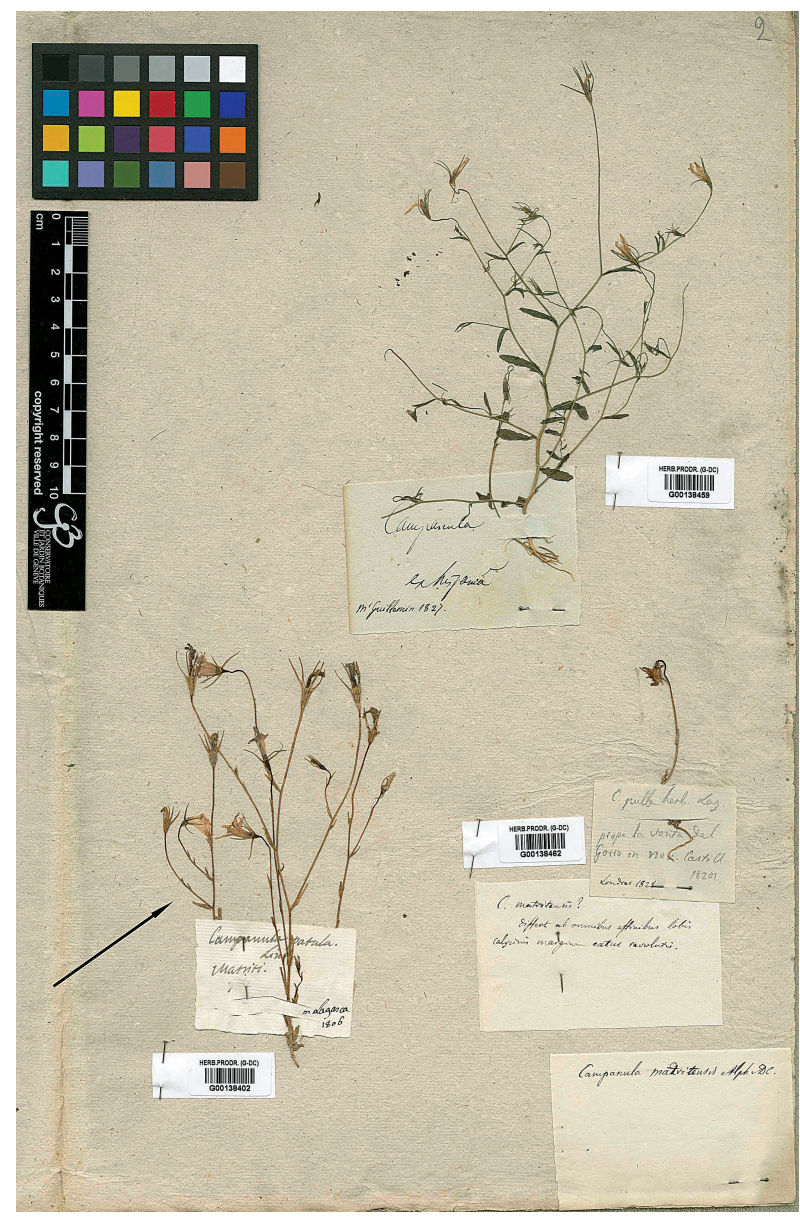

Fig. 6. Lectotype of Campanula matritensis (plant located in the lower left corner) (G 138402, indicated by the arrow). The lectotype is the plant of the center, the other two plants are isolectotypes. The other two plants with their respective labels are not material type. 
Alphonse De Candolle (1830). That these three plants include the type material is further indicated by an Alphonse De Candolle label at the bottom of the sheet with "Campanula matritensis Alph. DC.". Of these three plants, the largest, located in the middle, is chosen as lectotype of Campanula matritensis A. DC. The other two plants are isolectotypes. In the same sheet there are other two plants which are not type materials (see Fig. 6). One [Herb. Prodr. (G-DC)G 138459] indicates "Campanula/ex hispania/m' Guillemin 1827" and the plant, branched and young, is identified as C. matritensis; the other [Herb. Prodr. (G-DC)G 138462] indicates "C. pulla herb Lag./prope la Venta del Gorro in nov. Castell./1827 [1827? manuscript Lagasca?]/Londres 1828 [manuscript Lagasca]". Coupled with this label there is another, probably handwritten by A. De Candolle, with the following inscription: "C. matritensis?/differt ab ómnibus affinibus lobis/calicinis marginem extus revolutis.". Stitched to both labels there is a very small plant with a single flower, which we identify as $C$. dieckii Lange.

\section{Selected specimens}

PORTUGAL. Algarve: Broussailles à Monchique, 14-VI-1853, E. Bourgeau, in E. Bourgeau, Pl. d' Espagne et de Portugal, 1853: n ${ }^{\circ}$ 1943 (G 104070, G 104125, G 104140). Cabo de San Vicente, Chodat (G 104147). Castro Marim, Terras da Ordem, 24-IV-1975, M. Sequeira \& al. (HVR 4734). Entre Corte-Figueira y Mù, VI/VII1885, J. Daveau (LISU 36408). Faro, Santo Antonio do Alto, V1889, J. Brandeiro (G 104123). Olhão, Quinta de Marim, 24-V-1986, A. Moura (MA 430492). Entre Santa Catharina e Sagres, V-1906, F. Mendes E Palhinha (LISU 36391). Serra da Picota, VII-1891, J Brandeiro (COI). Serra de Monchique, Ribeira da Perna Negra, 30V-1979, M. Beliz \&J. Guerrero (MA 270313). Alto Alentejo: Elvas, próximo da estrada Elvas-Badajoz, 1-I-1900, A. Forque (LISE 31816). Évora, V-1891, A. Moller (COI). Évora Monte, entre Estremoz y Évora, 28-V-1996, S. Castroviejo \& al. (MA 588831). Gavião, 26-VI-1952, P. Silva, F. Fontes E B. Rainha (G 104102). Margen do rio Alirilungo, afluente de Xevora, V-1922, Fernandes (LISU 36417). Marvão, Serra de San Mamede, 16-V-1978, J.A. Devesa E J. Pastor (SEV 39778). Montargil, V-1883, G. Corteisão (COI). Mora, arredores nas arelas do leito da Ribeira da Raia, 13-V-1953, Bento Rainha (LISE 51183). Portalegre, Serra de Penha, VI-1882, A.R. da Cunha (LISU 36400). Portel, 15-V-1969, P. Silva \& al. (LISE 93823). Povoa e Meadas, VI-1882, A.R. da Cunba (LISU 36370). Redondo, V-1892, D. Pita Simões (LISU 36361, LISU 36366). Reguengos, Berrocal, IV-1908, F. Mendes E Palhinha (LISU 36411). Serra d'Ossa, V-1891, A. Moller (COI). Baixo Alentejo: Cazevel, V-1888, A. Moller (COI). Cuba, entre Cuba e Vila de Frades, 4-V-1962, M. Silva (LISE 76879). Entre Garvão e Panóias, VI/VII-1885, J. Daveau (LISU 36393). Odemira, V-1915, F. Gomez \& R. Machado (LISU 36415). Santiago de Cacém, 14-V-1958, B. Rainha, M. Silva E A.N. Teles (LISE 64924). Margen do rio Chança, VI-1913, F. Mendes, H. Navel E Palhinha (LISU 36414). Serra do Caldeirão, 12-V1905, M. Gandoger (G 104143). Sines, a $1 \mathrm{Km}$ a norte de porto Covo, 21-V-1982, F. Catarino \& al. (LISU 145357). Tarrão, 29-V1952, F. Fontes E al. (LISE 41814). Beira Alta: Águeda, perto de Escalhão, 26-V-1996, M. Santos E M. Sequeira (HVR 7845). Barca d'Alva, margen do Douro, VI-1915, F. Mendes E Palhinha (LISU 36416). Castelo Mendo, Moita do Carvalho, VII-1884, A.R. da Cunba (LISU 36399). Covilhã, VI/VII-1881, A.R. da Cunba (LISU
36395). Entre Guarda y Valhelhas, 16-VII-1983, S. Castroviejo E al. (MA 248455). Figueira de Castelo Rodrigo, Barca D’ Alva, 28-IV1943, J. Castro \& A. Rozeira (MA 514273). Sabugal, 14-VI-1976, I. Melo \& al. (LISU 69654). Serra da Estrela, VII-1887, A. Moller (MA 121501). Serra da Lapa e Mata da Vide, VI-1890, M. Ferreira (COI). Vale do Zêzere, 3-VIII-1949, C. Romariz (LISU 2053). Vouzela, $27-$ V-1940, Palhinha (LISU 36363). Sabugal, à saída da vila, na estrada Castelo Branco (Miradouro), 14-VI-1976, I. Melo, E al. (SEV 121226). Beira Baixa: Alcaide, Barroca do Chorão, VI-1882, A.R. da Cunba (LISU 36369). Castelo Branco, VI-1881, A.R. da Cunba (LISU 36398). Covilhã, nos latudes da estrada prose da ribeira da Carapinheira, 23-VI-1946, B. Rainha (G 104146, LISE 21736, MA 121494). Monfortinho, prox. das termas, 14-VI-1948, B. Rainha (LISE 22693, MA 152780). Tavanca do Mondego. 31-V-1990. Z. Díaz E al. (SEV 161692). Beira Litoral: Arganil, Moita, V-1895, M. Ferreira (COI). Cantanhede, VI-1888, C.M. Ferreira (COI). Choupal prope Conimbricam, VI-1878, A. Moller (G 104124, G 104122). Coimbra,, 6-VIII-1883, A. Moller (G 104139). Guardinha, arred. do Louriçal, VI-1897, J.A. Vaz Serra (COI). Meco, 16-IV1995, A. Crespi \& M. Sequeira (HVR 4604). Taboa, V-1883, A. Costa Carvalho (COI). Estremadura: Alfeite, V-1906, J. dos Santos (LISU 36384). Alrededores de Lisboa, Serra de Monsanto, VI-1884, A.R. da Cunba, in Flora Lusitanica (Soc. Brot. $7^{\circ}$. Anno) n 910 (LISU 36360). Arredores de Setúbal, V-1906, F. Gomez (LISU 36409). Lagoa de Albufeira, V-1882, J. Daveau (LISU 36371). Moita, Arganil, V-1895, M. Ferreira (COI). Praia das Maçãs, V-1930, F. Matos (LISU 36364). S. Simão, Piedade, VIII/IX-1848, J. Daveau (LISU 36396). Sacavém, 1952, Duarte de Castro (LISE 40720). Seixal, V-1881, A.R. da Cunba (LISU 36397). Serra da Arrabida, Colina de Santa Margarida, 18-V-1942, C. Fontes \& al. (LISE 15267, MA 121496). Serra de Montejunto, 31-I-1947, Romariz \& Mendes (LISU 56937). Sesimbra, Alfarim, 2-VI-1971, M. Beliz \& J. Guerreiro (MA 270318). Vila Nogueira, 25-V-1978, J.A. Devesa \& al. (SEV 39777). Minho: Gerez, VII-1889, F. Loureiro (COI). Valença, Olivar de Sta. Barbara, VI-1885, A.R. da Cunba (COI). Ribatejo: Almeirim, 22-V1952, P. Silva \& M. Silva (LISE 41804). Trás-os-Montes: arred. de Miranda do Douro, Iffanes, VI-1888, J. de Mariz (COI). Arredores de Bragança, 16-VI-1941, A. Carneiro (COI). Arredores de Moncorvo, Concelho de Mogadouro, Urrós, 20-V-1997, J. Hernándes E E. Rico (SALA 90849). Avelanoso, arred. de Vimioso, VI-1888, J. de Mariz (COI). Ligares, V-1884, J. de Mariz (COI). Valença, Olival de Santa Barbara, VI-1885, A.R. da Cunba (COI). Vila Real, Coêdo, 10VII-1981, A. Além (COI).

SPAIN. Álava: Bernedo, Urturi, 1-VII-1987, J.A. Alejandre (MA 423674). Albacete: San Pedro, 11-VI-1984, J.M. Herranz (MA 318970). Almería: Abrucena, Las Rozas, 17-VI-1988, B. Valdés E al. (G 104090). Ávila: Arévalo, 20-VI-1971, J. Gómez (MA 432025). Castronuevo, 19-VI-1984, Barrera E al. (MA 314814, SALA 34644). Hoyocasero, Cueva del Moragato, 15-VI-1985, M. Luceño \& P. Vargas (MA 407310). Hoyos del Espino, Las Chorreras, 9-VII-1988, Aizpuru E al. (MA 451362). Piedralaves, La Adrada, 22-VI-1982, F. de Diego Calonge (MA 538909, MA 538611). Poyales del Hoyo, 30 VI-1917, J. Cuesta (MA 121528). Ramacastañas, Cerro de las Cuevas del Águila, 30-V-1987, Vargas (MA 655999). Sierra de Ojos Albos, Los Regajales, 3-VII-1984, A.R. Burgaz E al. (MA 389677). Sotillo de la Adrada, 15-VI-1973, G. López E E. Valdés Bermejo (MA 430972). Valle de Iruelas, 12-VI-1956, C. Vicioso (MA 170174). Venta del Obispo, 20-VI-1945, A. Caballero (MA 121586). Villanueva de Gómez, 19-VI-2003, M. Ladero (SALA 108263). Valle de Amblés, Villatoro, 12-VII-1974, Ladero E Fuertes (SALAF 23155). Badajoz: Campanario, V-1911, V. Lagares (MA 121534). Castuera, 14-IV-2001, P. Escobar García (MA 707044). El Berrocal, 25-V2001, P. Escobar García (MA 707042). El Toril, V-1951, Moreno Márquez (SEV 5005). Mérida, embalse de Proserpina, 16-IV-1994, F. Amich \& al. (MA 717798). Oliva de la Frontera, 23-IV-1994, F. Amich E al. (MA 717195). Sierra del Palenque, 7-V-2000, P. Escobar 
García (MA 766400). Talarrubias, 19-V-2001, P. Escobar García (MA 707043). Valdecaballeros, 17-III-1977, M. Figueroa \& al. (MA 269851). Burgos: Aranda de Duero, V-1942, A. Caballero (MA 121572, MA 121526). Cardeñajimeno, 21-VI-1914, C. Pau (MA 121533). Ciruelos de Cervera, pie del Alto de la Cabeza, 11-VII1979, Pons Sorolla E Susanna (G 104082, MA 413025). De Quintanar de la Sierra a Neila, 1-VII-1925, M. Losa (MA 433608). La Revilla, camino de Ahedo, 17-VII-1979, Muñoz Garmendia E al. (G 104085, MA 414202). Miranda de Ebro, 15-VI-1912, H. Elias (MA 433606). Santa Gadea del Cid, 11-VII-1915, H. Elías, in F. Sennen, Plantes D’ Espagne, n’ 2447 (MA 121573). Tejada, Pico Valdosa, 3VII-1979, J. Fernández Casas É al. (G 104084). Cáceres: Baños de Montemayor, 15-IV-1944, A. Caballero (MA 121543). Barrado, 19V-1988, A. Amor (SALAF 16729, SALAF 23633). Cañaveral, cerro de Cabezarrubias, 14-V-1988, Ladero E Santos (SALAF 16506). Casatejada, Las Cabezas, Sexta Suerte, Arroyo de Fresno, 7-V-1983, Ruiz Téllez (SALAF 6774). En las bajadas de Puerto Viejo, hacia Valverde del Fresno, 23-V-1982, A. Valdés Franzi (SALAF 12190). Guadalupe, 16-VI-1948, A. Caballero (MA 121539). Hervás, 12-X1987, R. González (SALA 101150). Jaraíz de la Vera, Las Costeras, 19-V-1988, A. Amor (SALAF 16703). La Bazagona, 1-V-1983, Ruiz Téllez (SALAF 6775). Losar de la Vera, Valle del Tiétar, 20-III1980, Meana $\varepsilon$ al. (MA 393441, SANT 18476). Mirabel, 4-V-1980, D. Belmonte (MA 344687). Montánchez, Sierra de Montánchez, carretera a Cerro Moro, 20-VI-1998, S. Castroviejo (MA 613395). Navalmoral de la Mata, 25-V-1984, Ruiz Téllez (SALAF 10761, MA 680829). Plasencia, 19-V-1988, Ladero E al. (SALAF 16507). Puerto de Hoyos, 17-VII-1978, A. Valdés Franzi (SALAF 12191). Puerto de Santa Clara, San Martín de Trevejo, 28-VI-1983, M. Ladero E A. Valdés (SALA 114203, SALAF 12192). Santiago de Alcántara, 26IV-1994, F. Amich E al. (MA 718573). Sierra de San Pedro, 17-V1909, M. Gandoger (G 104144). Torrecillas de la Tiesa, 22-V-1999, L. Medina (MA 624469). Valle del Jerte, 18-VI-1975, Carrasco \& Castroviejo (SALA 25804). Cádiz: Algodonales, Sierra de Lijar, 11VII-1980, A. Aparicio \& al (SEV 57983). Aprox. $5 \mathrm{~km}$ al E de Vejer de la Frontera, entre los pinos a lo largo de la carretera, 28-IV-1975, S. Holmdahl (MGC 50213). Bornos, 28-IV-1978, B. Molesworth Allen (SEV 53284). Chiclana de la Frontera, 22-V-1982, A. Charpin E C. Defferrand (G 104083, MA 243115). Grazalema, Puerto de las Palomas, 10-VI-1993, A. Aparicio \& al. (MA 526987). Jeréz de la Frontera, 17-V-1985, A. Asensi \& J. Cuenca (MA 570487). Los Barrios, Barranco del Arroyo de Valdeinfierno, 28-V-1978, J. Fernández Casas (G 104086, MA 226312, SALA 22564). Puerto de Santa María, Chiclana, et pr. Grazalema, V-1895, Porta \& Rigo, Iter IV Hisp. 1895: 321 (G 104107). Sierra de Palma, 19-VII-1887, E. Reverchon, in E. Reverchon, Plantes de L'Andalousie, 1887: $\mathrm{n}^{\circ} 17$ (MA 121509). Tarifa, Sierra de Saladavieja, El Carrascal, 22-VII1980, J. Arroyo E J.M. Gil (SEV 64621). Ubrique, 30-V-1972, S. Holmdabl (MGC 50212). Cantabria: Valderredible, páramo de la Lora, 2-IX-1983, E. Loriente (MA 683841, MA 599290). Ciudad Real: Argamasilla de Calatrava, finca La Laguna de las Carboneras, 13-V-2001, M. Bellet E al. (MA 711976). Cabezarrubias del Puerto, 22-V-1998, R. García Ríos (MA 711940). Casas del Río, Navalagrulla, 1-VI-2001, S. Castroviejo E M. A. Carrasco (MA 692324). Sierra de Alhambra, 30-IV-1933, González Albo (MA 121583). Sierra Madrona, 29-V-1950, S. Rivas Goday \& J. Borja (SALA 376). Sierra Morena, Venta de Cárdenas, 30-IV-1933, J. Cuatrecasas (MA 121520). Córdoba: Belalcázar, finca de Pedroche, 8-VII-1976, J.A. Devesa (SEV 33720). Cardeña, finca de Yegüerizo (UH-83), 30-V1976, J.A. Devesa (SEV 33723). Torrecampo, ribazos del río Guadamora, 16-V-1976, J.A. Devesa (SEV 33388). Trassierra, 14-V-1982, J. Arroyo (SEV 87091). Villaviciosa de Córdoba, Tres puentes, V1920, C. Pau (MA 121518). Cuenca: Ródenos de Cañete, 9-VI-1971, E. Valdés Bermejo \& al. (MA 431991). Talayuelas, 18-VI-1979, G. Mateo (MA 256531). Granada: Cañar, Bco. río Chico, 20-VII1979, J. Molero Mesa (MA 432023). Capileira, 3-VII-1948, Vieiter
(SANT 211). In arenosis Regn. Granat. a littore, 1837, E. Boissier (G 104111). Jatar, Sierra Almijara, supra Jatar, 11-VI-1983, B. Cabezudo EJ.M. Nieto (MGC 41527). Puerto de la Ragua, cruce con la carretera a la Alpujarra, 19-VI-1988, B. Valdés E al. (G 104089). Sierra Nevada, 21-VII-1879, Huter \& al. Extinere hispanico 1879: 234 (G 104137); ibidem, Cáñar, 28-VII-1930, C. Vicioso (MA 121558). Guadalajara: Campillejo, VII-1973, Demetrio (FCO 4103). Cantalojas, Valle del Lillas, 20-VI-1985, Burgos E Cardiel (MA 487000). Checa, 25-VI-1997, L.M. Ferrero \& L. Medina (MA 595634). El Pedregal, VII-1894, J. Benedicto (MA 121566). La Fuensaviñán, 26-V1994, J. Castillo \& al. (MA 543882). Prado Redondo, Monte del Condado (MA 153134). Valverde de los Arroyos, 13-VII-1998, F. Lamata (MA 615546). Guadalajara, VI-1994 (MA 546347). Huelva: Almonte, 28-IV-1943, C. Vicioso (MA 121510); ibídem, 12-V-2006, A. Quintanar (MA 772195). Ayamonte, 5-V-1902 (MA 121515). Calañas, 28-IV-1921, Gros (MA 121513). Chucena, Cerro de las Palomas, 19-IV-2001, B. Cabezudo \& al. (MGC 48566). Higuera de la Sierra, 24-V-1988, E. Bayón E E. Villanueva (MA 438689). Hinojos, 26-V-2004, J. Cano-Maqueda E al. (SEV 216214). La Barra de Huelva, 22-IV-1943, C. Vicioso (MA 121512). Sierra de Aracena, Aracena, 15-V-1979, J. Rivera (SEV 48340). Jaén: Andújar, El Abogado, 11-V-1985, E. Cano (MA 716641). Baños de la Encina, mina Matacabras, 23-IV-1988, C. Fernández E al. (FCO 21720, G 104155, MA 553899, MGC 38654, SALA 59048, SANT 29973). Guarromán, camino hacia la mina de los Dolores, 5-V-1966, S. Silvestre (SEV 19712). Sierra Morena, Arroyo de Oruga, 7-VI-1923, Fernández E al. (MA 121519). La Rioja: Ezcaray, barranco Reoyo, pr. Urdanta, 16-VII-1998, Gracía-Baquero \& al. (SALA 100212). Ocón, 27-VII-1930 (MA 121531). San Millán de la Cogolla, 16-VII1981, S. Castroviejo E Fernández Quirós (MA 433427). Sierra de la Demanda, de Anguiano a Tabladas, 26-VII-1995, L. Loidi E A. Berastegui, in Lambinon, Pl. Europe Occid.-Bas. Méd., 1997: n 17459 (G 104092, MA 589694). León: Castroquilame, 12-V-1973, Andrés E Carbó (SEV 16643). La Gotera, 8-VII-1944, Rojas (MA 121550). Ponferrada, 10-VII-1933, W. Rothmaler, in W. Rothmaler, Plantae Hispaniae Boreali-Occidentalis, $n^{\circ} 128$ (MA 121551); ibidem, carretera de San Esteban de Valdueza a San Pedro de Montes, 21-VI1981, Alamillo \& Nieto (MA 317259). Trabadelo, San Fiz do Seo, valle del río Barjas, 18-VII-1998, Martín-Blanco (MA 641637). Lugo: Tardad, Villalba, 30-VII-1951, M. Orosa (G 104101). VillardíazFonsagrada, 22-VII-1953, E. Carreira (G 104197). Madrid: Madrid, VI-1841, Reuter (G 104130, G 104131). Buitrago, 1-VI-1918, C. Vicioso (MA 121559). Collines à la base de la Sierra de Gredos, 8-VII1863, E. Bourgeau, in E. Bourgeau, Pl. d'Espagne et de Portugal, 1863: n 2442 (G 104127, G 104132, MA 721360, MA 121530, MA 121529, MA 152777). Casa de campo pres Madrid, 7-VI-1854, E. Bourgeau (G 104128, G 104145, MA 720519). Chamartín, 17-V, Isern (MA 153136). Chinchón, cerros de Butarrón, VI-1919, C. Vicioso (MA 121576). El Escorial, VI-1914, C. Vicioso (MA 121577). El Pardo, 4-VI-1936, M. Martínez E A. Rodríguez (MA 432685). Guadalix de la Sierra, 29-VI-1983, F. Gómez Manzaneque (MA 450150). Hoyo de Manzanares, VI-1998, A. Izuzquiza \& al. (MA 615516). La Pedriza, V-1932 (MA 432723). Miraflores, 25-VI-1945, L.C. E A.R. (MA 201400). Monte del Pardo, 20-V-1917, C. Vicioso (MA 121578). Montejo de la Sierra, 2-VII-1954, A. Rodríguez (G 104103). Navacerrada, VI-1915, C. Vicioso E Beltrán (MA 121580). Puerto de la Cruz Verde, 22-VI-1973, Rivas-Martínez \& Costa (MA 432036). Robledo de Chavela, 19-VI-1988, M. Costa Tenorio \& H. Sainz Ollero, in J. Lambinon, Pl. Europe Occ.-Bas. Méd. 1993: $\mathrm{n}^{\circ} 15575$ (G 104153, MA 532060, SALA 88527). San Martín de Valdeiglesias, Rozas de Puerto Real, 6-VI-1992, P. Vargas (MA 515427). Sierra de Guadarrama, 4-VII-1968, O. Polunin (MGC 5003). Sierra de la Cabrera, 4-VII-1993, A. Izuzquiza \& al. (MA 529567). Torrelaguna, V-1912, C. Vicioso (MA 121582). Málaga: Benaoján, Sierra del Palo, 27-V-2007, J. Cano-Maqueda (SEV 218872). Benarrabá, carril de los Pepes, 29-V-2004, O. Gavira 
(MGC 60964). Casares, Monte del Duque, 20-V-1988, B. Cabezudo E A.V. Pérez-Latorre (MGC 35466). Estepona, 16-V-1919, E. Gros (MA 121506). Gaucín, VI-1916, E. Gros (MA 121508). Gobantes, garganta de El Gaitán, 11-VI-1930, C. Vicioso (MA 121486). Los Villares, 12-V-1988, B. Cabezudo \& al. (MGC 24576). Ronda, 07VI-1889, E. Reverchon, in E. Reverchon, Plantes de L'Andalousie 1889: ${ }^{\circ} 17$ (G 104260). Sedella, Los Picaricos, 30-V-2003, B. Cabezudo \& al. (MGC 60070). Sierra Bermeja, 18-V-1919, E. Gros (MA 121507). Sierra Tejeda, 26-VI-1982, J.M. Nieto (MGC 18110). Tolox, Castañar de los Hornillos, 13-VI-1932, L. Ceballos (MA 121505). Torrox, VI-1909, Domingo (G 104138). Orense: Lovios, 6-VI-1993, I. Pulgar (FCO 21431, MA 551003). Serra do Invernadeiro, entre Rocín y Suacenza, 11-VII-1973, S. Castroviejo (G 104080). Salamanca: Cantalapiedra, 25-V-1987, X. Giráldez E Aragón (SALA 46173). Ciudad Rodrigo, 4/6-VII-1932, C. Pau (MA 121549). Embalse del río Águeda, 6-VI-1976, E. Rico (SALA 9431). Entre Fuentes de Béjar y Navas de Béjar, 21-VI-1978, J.A. Devesa E J. Pastor (SEV 39776). Entre La Alberca y Sotoserrano, 20-VII1972, Fernández Díez (SALA 5451). Guijuelo, 7-VI-1987, E. Rico E J. Serradilla (MA 476539, SALA 46836). Hurdes, 5-VII-1946, A. Caballero (MA 121547). Ledesma, 19-V-1976, J. Sánchez (SALA 17419). Linares de Riofrío, VII-1980, J. L. Fernández Alonso (MA 519040). Masueco, laderas del río Uces, 16-VI-1976, F. Amich (SALA 15517). Monleras, 22-X-1976, J. Sánchez (SALA 17428). Montemayor del Río, 3-VII-1983, A. Guillén (SALA 36167). Navacarros, 15-VII-1983, F. Amich \& F. Herrero (SALA 34909, SALA 34910). Pelabravo, 2-VI-1990, A. Pastor (SALA 57034). Peñamecer, 23-V-1976, J. Sánchez (MA 219749, SALA 17427). Puerto Seguro, 9-V-1976, E. Rico (SALA 9432). San Esteban de la Sierra, 20-VI-1971, Fernández Díez (SALA 5595). Topas, 9-VI1967, B. Casaseca (SALA 375). Valdelageve, 28-IV-1996, J. Barrios Pérez (SALA 121888, SALA 121889). Segovia: Aguilafuente, Cotarra de Juriñas, 6-VI-2002, M. Pérez Valero (MA 756780). Entre Riaza y Ayllón, cruce de la carretera hacia Pajares del Fresno, 28-V1992, A. Izuzquiza (MA 508024). Fresno de la Fuente, 20-VI-1985, A. Izuzquiza (MA 348898). Fuentidueña, 15-VI-1983, T. Romero (SALA 40297). Lastras de Cuéllar, Molino Ladrón, 24-V-1998, P. Bariego Hernández E A. Gastón González (MA 754632). Ochando, 19-VI-2002, M. Sanz Elorza (MA 687112). Puerto de los Cotos, 5 VII-1989, A. Charpin E P.A. Loizeau (G 104151). Riofrío de Riaza, 7-IX-1975, F.J. Fernández Casas (MA 347715). Siguero, 1-VII-1983, T. Romero (MA 567697). Torrecilla del Pinar, 12-VII-1984, T. Romero (SALA 40298). Sevilla: al S de Villamanrique de la Condensa, 7-V-1988, E. Bayón E al. (MA 438338). Aznalcázar, 20-IV-2003, Z. Díaz (MA 707168). Castilblanco de los Arroyos, Los Melonares, 1-VI-2006, J. Cano-Maqueda E al. (SEV 218870). Constantina, Hermita Virgen de Robledo, 1-VI-2006, J. Cano-Maqueda E al. (SEV 218869). Dehesa de Covarrubias, 6-IV-2001, B. Cabezudo \& al. (MGC 48568). Gerena, 3-V-2001, B. Cabezudo \& al. (MGC 48568). Paradas, 5-V-1933, C. Vicioso (MA 121517). Soria: Berlanga de Duero, 18-VI-1977, A. Segura Zubizarreta (G 104087, MA 226315. SALAF 437, SEV 74840). Canredondo, 22-VI-1990, A. Segura Zubizarreta (MA 581101). Cañón del río Lobos, 30-VI-1983, A. Buades (MA 504440). Carbonera de Frentes, 2-VII-1989, A. Charpin (G 104152). Herrera de Soria, 30-VI-1983, A. Buades (MA 504408). Molinos de Duero, 21-VIII-1987, G. Mateo (MA 383713). Quintana Redonda, 30-VI-1974, A. Segura Zubizarreta (SEV 41098). Tozalmoro, 6-VII-1935, C. Vicioso (MA 121527). Teruel: Orihuela del Tremedal, 18-VI-1907, C. Pau (MA 433607). Segura de los Baños, VII-1894, J. Benedicto (MA 121566b). Toledo: Almorox, El Pinar, 3-VII-1982, M. Luceño (MA 430416). Nacimiento del río Estena, 19-VI-1986, J. Assens \& al. (MA 430409). Valladolid: Castronuño, Sendero de los Ladrones, 22-V-1988, G. Balbás (SALAF 23342). Pedrajas de San Esteban, 7-VII-1975, F.J. Fernández Diez (FCO 4601, SALA 7575). Zamora: Aspariegos, La Salgada, 10-V-1990, R. García Ríos (SALA 54046). Corrales, 15-VI-1951, Casaseca (SANT
5565). Cubo del Vino, 19-VI-1981, X. Giráldez (SALA 31612). Escober, Los Linares, 15-VII-1996, P. Bariego Hernández (MA 651736). Lago de Sanabria, 25-VIII-1953, A. Rodríguez (MA 201347). San Cebrián de Castro, El Barrucal, 28-V-1990, R. García Ríos (SALA 54048). Villaseco del Pan, La Era del Campo, 30-IV1988, R. García Rios (SALA 54047). Zaragoza: Atea, 29-V-1909, C. Vicioso (MA 121565). Calatayud, VI-1987, C. Vicioso (MA 121560). Moncayo, 19-VII-1893, C. Vicioso (MA 121560). Belmonte, 4-V1931, Gros, in F. Sennen, Plantes d' Espagne 1932: nº 8206 (G 104149, MA 121514).

3. Campanula cabezudoi Cano-Maqueda \& Talavera in Acta Bot. Malacitana 32: 254. 2007

C. decumbens var. pseudospecularioides G. López in Bol. Soc. Brot. ser. 2, 53: 301 (1979-1980) [syn. subst.]. Ind. loc.: "Habitat locis umbrosis, inter rupes calcareas, loco dicto Boquete de Zafarraya, Sierra Tejeda (Málaga-Granada), ubi cum P. Cubas et J.M. Moreno, die 28-VI-1976, legi. Holotype: MA 210975, Fig. 7; Isotype: MA 210994”.

Illustrations: Gallego (1987: 564, as C. decumbens);

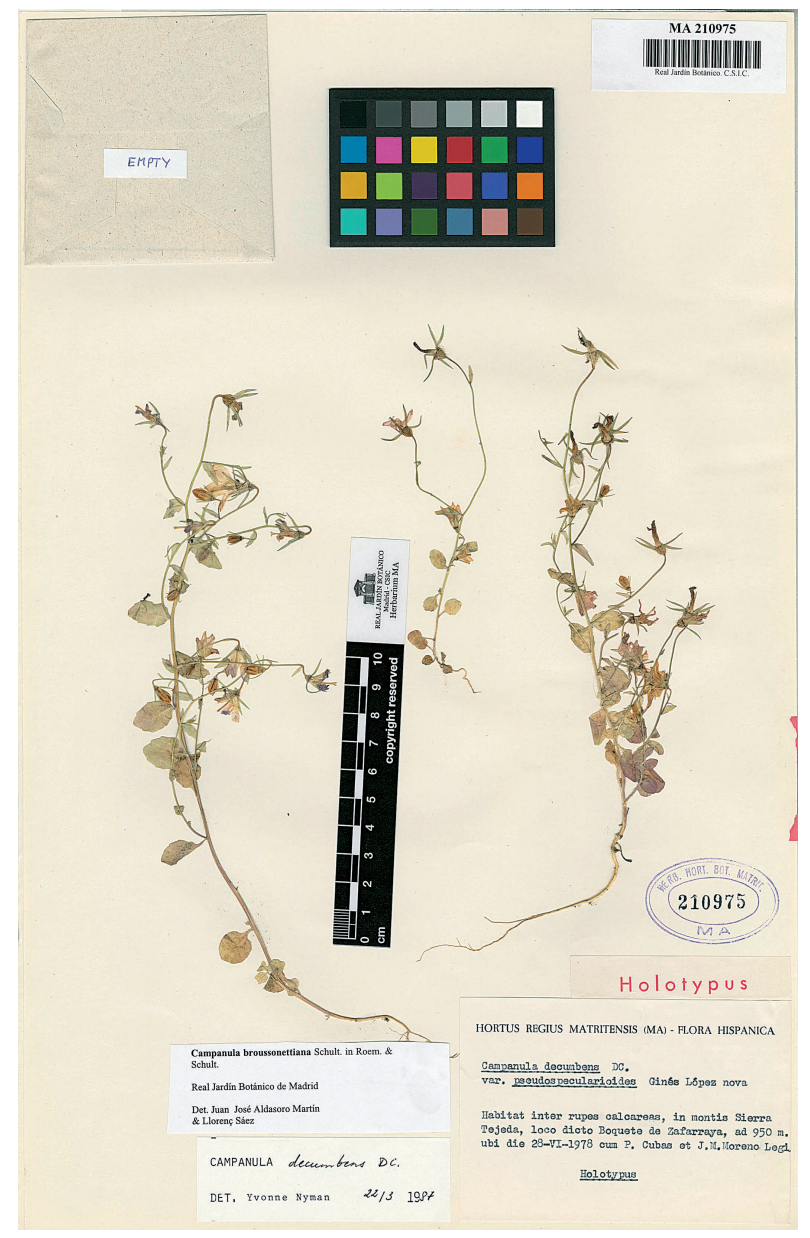

Fig. 7. Holotype of Campanula cabezudoi (MA 210975). 
Sáez \& Aldasoro (2001: 130, fig. 39a, as C. lusitanica subsp. lusitanica); Fig. 4 E, F.

Herb 8-30(45) cm, annual, decumbent, branched from the base, pubescent, not brittle. Stems slightly angled, branched, pubescent, sometimes glabrescent at the apex, with setose hairs of 0.1-1.4 mm. Leaves subcoriaceous, entire or toothed, petiolate; middle cauline leaves 6.2-18.2 × (2.9)5-9 mm, petiolate, elliptical, \pm pubescent, with hairs to $1.1 \mathrm{~mm}$, with petioles up to $2 \mathrm{~mm}$; upper cauline leaves 4.5-14.5 × 1.3-3.9 $\mathrm{mm}$, oblanceolate, \pm hairy, with hairs up to $1.2 \mathrm{~mm}$, with petioles of c. $0.5 \mathrm{~mm}$. Inflorescence laxly paniculate. Flowers pedicellate; pedicel (9.8)20-68 mm, glabrous or setose, with hairs of 0.1-0.7(1.5) mm. Calyx-teeth (4)5-11 × 0.4-1.2 mm, lanceolate or linear. Corolla (7.3)8-16 mm, infundibuliform, with the tube shorter than the lobes; tube 3.1-6.9 mm, white; lobes (3.6)5-10.3 × 3.1-6.2 mm, elliptic, blue, with three purple nerves. Stamens with enlarged base of $0.6-1 \times$ 0.5-0.7 mm, deltoid; filaments $0.4-0.5 \mathrm{~mm}$; anthers (2.5)3-6.4 mm, whitish. Ovary densely hispid, with setose hairs $0.2-1.8 \mathrm{~mm}$; style (5)7-12.3 mm, hairy in the upper half; stigma trifid, with stigmatic branches 1$1.7 \mathrm{~mm}$, patent, arched, white. Capsule 2.1-5.9 × 2.2$5 \mathrm{~mm}$, subspherical or ovoid, generally wider than long, densely hairy, with papillose hairs up to $1.5 \mathrm{~mm}$, with 10 nerves \pm acute but not winged, dehiscing by three apical pores. Seeds 0.5-0.6 $\times 0.2-0.3 \mathrm{~mm}$, ovoid, shining, yellowish to brown. $2 n=20$.

Habitat, phenology and distribution: Fissures of calcareous rocks; 400-1600 m. VI-VII. •Endemic to the Sierra Subbética from Seville to Jaén, and the Penibética, where it is very frequent, especially in the Sierra de Loja and Tejeda (Fig. 8). Spain: Ca Co Gr J Ma Se.

Observations: Sáez \& Aldasoro (2001) comment with reference to $C$. decumbens var. pseudospecularioides G. López: "existen formas intermedias entre esta subespecie [which they refer to C. specularioides] y $C$. decumbens [which they refer to $C$. dieckii], que han recibido reconocimiento taxonómico". It is very likely that they are referring to C. cabezudoi. In fact, the vegetative characters of decumbent habit and the presence of petiolate middle leaves of the stem,

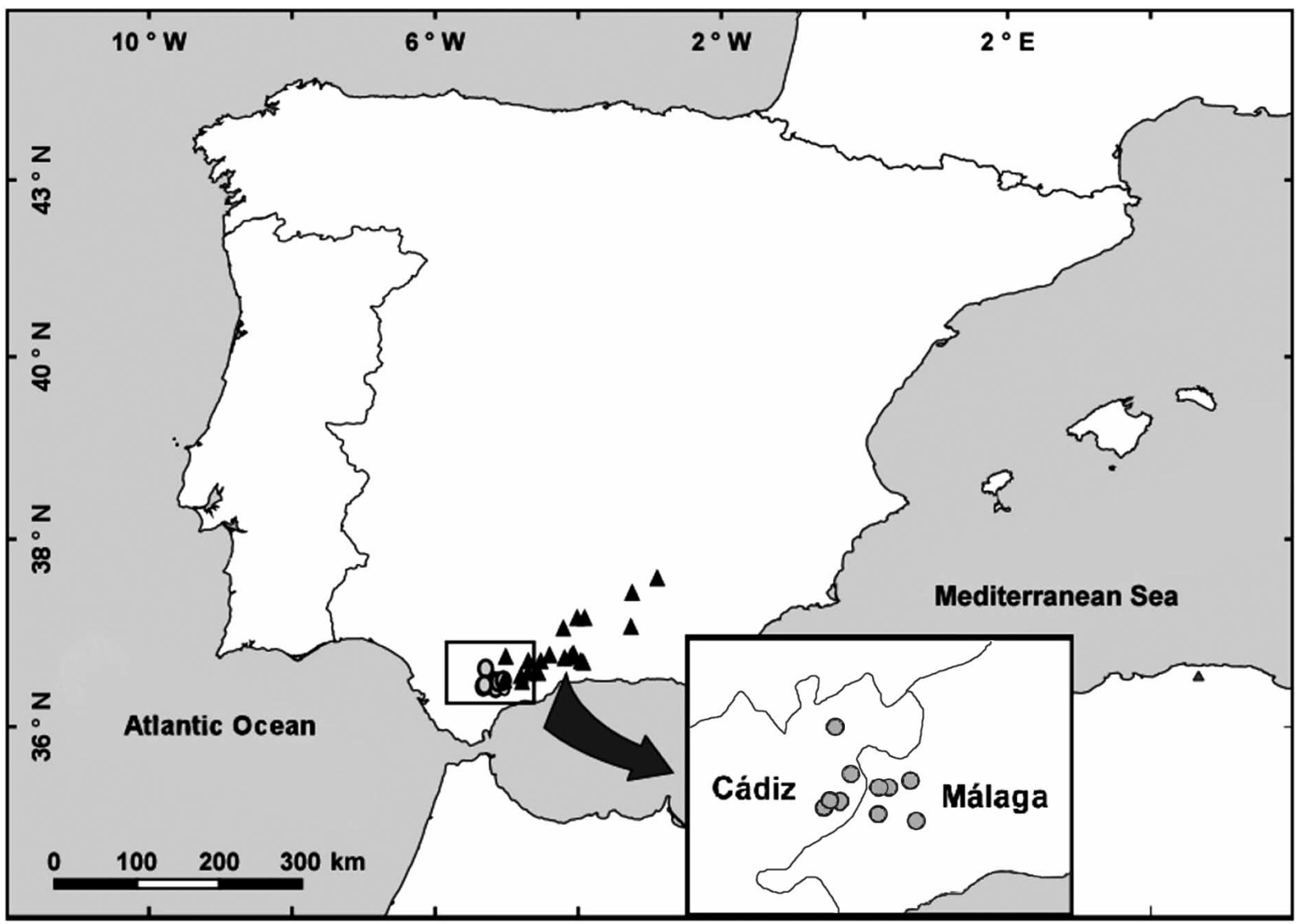

Fig. 8. Distribution map of Campanula cabezudoi $(\mathbf{\Lambda})$ and C. specularioides (O). 
are similar in C. cabezudoi and C. decumbens, but C. cabezudoi has hairy style in the upper half and a single trifid stigma with curved and patent stigmatic lobes, while $C$. decumbens has a glabrous style and three straight and erect-patent stigmas. Moreover, in the topology of the ITS analysis, C. cabezudoi and C. decumbens are in two different clades (Fig. 1) and they have different chromosomes number (Table 1, Fig. 2).

\section{Selected specimens}

SPAIN. Cádiz: Grazalema, Puerto de las Palomas, El Pinar, 5 VII-1984, A. Aparicio (SEV 161693). Córdoba: Almedinilla, Sierra de Albayate, 7-VI-1980, J. Muñoz (MA 749306). Priego de Córdoba, Sierra Horconera, 4-VII-1980, J. Muñoz \& R. Tormo (MA 749309). Rute, Sierra de Rute, Pico Las Cruces, 26-VI-1978, J. Muñoz (MA 749308, SEV 161894). Granada: entre Venta de Zafarraya y Zafarraya, Sierra Gorda, VI-2007, Cano-Maqueda E al. (SEV 218873). Sierra Harana, cercanías de la Cueva del Agua, 16 VI-1982, Casares E al. (MA 432054). Sierra Tejeda, 7-VII-1935, M. Laza (MA 121470). Jaén: Mágina, 3-VII-1925, J. Cuatrecasas (MA 121522). Sierra de Cazorla, El Tranco, 30-VI-1988, S. Talavera E al. (G 104061, SEV 161662). Málaga: Alfarnate, Sierra de la Torca, 7-VI-2006, B. Cabezudo E al. (MGC 63804). Álora, Sierra de Huma, 26-VI-1986, B. Cabezudo \& R. Suan (MGC 36711). Antequera, 14-VI-1930, C. Vicioso (MA 121488). De Ronda a El Burgo, 18-VI-1972, L. Bernardi (G 104157). Los Alazores, Puerto de los Alazores, Sierra de Alhama, Tres Mogotes, 5-VII-1973, B. Cabezudo E B. Valdés (SEV 161891). Puerto del Viento, 29-VI1849, E. Bourgeau in Bourgeau, Pl. Espagne 1849: nº 320 (G 104256). Sierra Prieta, 07-VI-1879, Hunter, Porta E Rigo in Iter. Hisp. 1879: $n^{\circ} 232$ (G 104184). Ronda-Sierra de las Nieves, entrando al Sabinar, Monte de la Peineta, 19-VI-1974, S. Talavera E B. Valdés (SEV 161889). Sierra de Peñarrubia, 12-VI-1930, C. Vicioso (MA 121487). Valle de Abdajalís, cortado del Cuervo, 15-VI1973, S. Talavera \& B. Valdés (SEV 161888). Villanueva del Rosario, Sierra Camorolos, 5-VII-1973, B. Cabezudo E B. Valdés (SEV 161887). Yunquera, P. N. Sierra de las Nieves, entre el Puerto Bellina y el cruce del camino con la Cañada de los Hornillos, 18VI-1998, B. Cabezudo \& al. (MGC 46750). Sevilla: Algámitas, Sierra del Tablón, 5-VII-1978, B. Cabezudo E E. Ruíz de Clavijo (SALA 13425, SEV 31778).

4. Campanula specularioides Coss., Notes Pl. Crit.: 41.1849

C. lusitanica subsp. specularioides (Coss.) Aldasoro \& L. Sáez in Anales. Jard. Bot. Madrid 59: 173. 2001. Ind. loc.: "In fissuris rupium regionis montanae regni Granatensis, loco dicto Cortijo blanco prope Ronda, a Bourgeau inventa”. Type: Spain. Málaga, Ronda, Cortijo Blanco, 20 June 1849, Bourgeau s.n. [Pl. D'Espagne, 1849] (lectotype, here designated, P 185468!, Fig. 9; see observations).

Illustrations: Gallego (1987: 565); Sáez \& Aldasoro (2001: 130, fig. 39i-m, as C. lusitanica subsp. specularioides); Fig. $10 \mathrm{~A}, \mathrm{~B}$.

Herb 6-26 cm, annual, decumbent, branched from the base, glabrous or glabrescent, very brittle. Stems angled, branched, glabrous, rarely with setiform hairs to $1.2 \mathrm{~mm}$. Leaves fleshy, entire or toothed, petiolate; middle cauline leaves $7.5-13.4 \times 4.5-20 \mathrm{~mm}$, broadly elliptical, glabrous or glabrescent, with hairs 0.1-0.2 $\mathrm{mm}$, and petiole 1-6.4(14) $\mathrm{mm}$; upper cauline leaves 3.5-14.5 × (1)1.9-6.4 mm, elliptic, glabrous, with petiole $0.4-1.7 \mathrm{~mm}$. Inflorescence laxly paniculate. Flowers pedicellate; pedicel (5.7)7-35 mm, glabrous or setose hairs 0.1-0.8 mm. Calyx-teeth (1.7)3-7.6 × 0.7-1.5 $\mathrm{mm}$, oblanceolate. Corolla (6.6)8-10(14) mm, broadly infundibuliform, with the tube shorter than lobes; tube 2.6-4.9 mm, whitish; lobes 4.1-7.5(10.3) × 2.2$5.4 \mathrm{~mm}$, elliptical, pinkish or bluish, with three purple nerves. Stamens with enlarged base of 0.5-1 × 0.2-0.5 $\mathrm{mm}$, deltoid; filaments $0.6-0.8 \mathrm{~mm}$; anthers $2.1-3.2$ $\mathrm{mm}$, blue or whitish. Ovary glabrous, rarely densely hairy; style (4.7)6-7.3(8.5) $\mathrm{mm}$, hairy in the upper half; trifid stigma, with stigmatic branches 0.6-1(1.4) mm, patent, curved, white or blue. Capsule 2-3 × 3-4.5 $\mathrm{mm}$, subspherical, wider than long, with 10 subwinged, glabrous nerves, rarely with setose hairs up to $1.5 \mathrm{~mm}$, dehiscing by three pores of middle position.

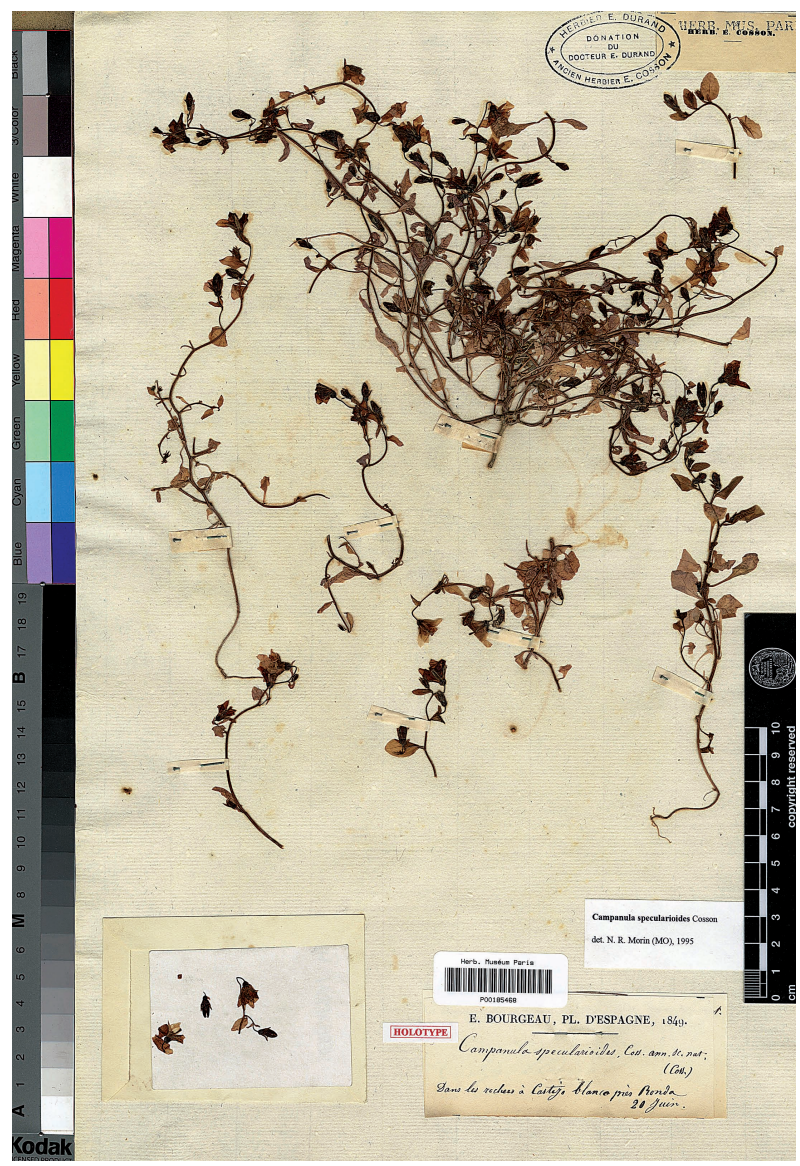

Fig. 9. Lectotype of Campanula specularioides (P 185468, herb. Cosson). 
Seeds 0.5-0.7 $\times 0.2-0.3 \mathrm{~mm}$, ovoid, shining, yellowish to brown. $2 n=20 ; n=10$.

Habitat, phenology and distribution: In crevices in walls or limestone rocks; 500-1650 m. V-VI(VII). •En- demic to Sierra de Grazalema and Serranía de Ronda (Fig. 8). Spain: Ca Ma.

Observations: Despite its narrow distribution, this species is markedly variable in the colour of anthers
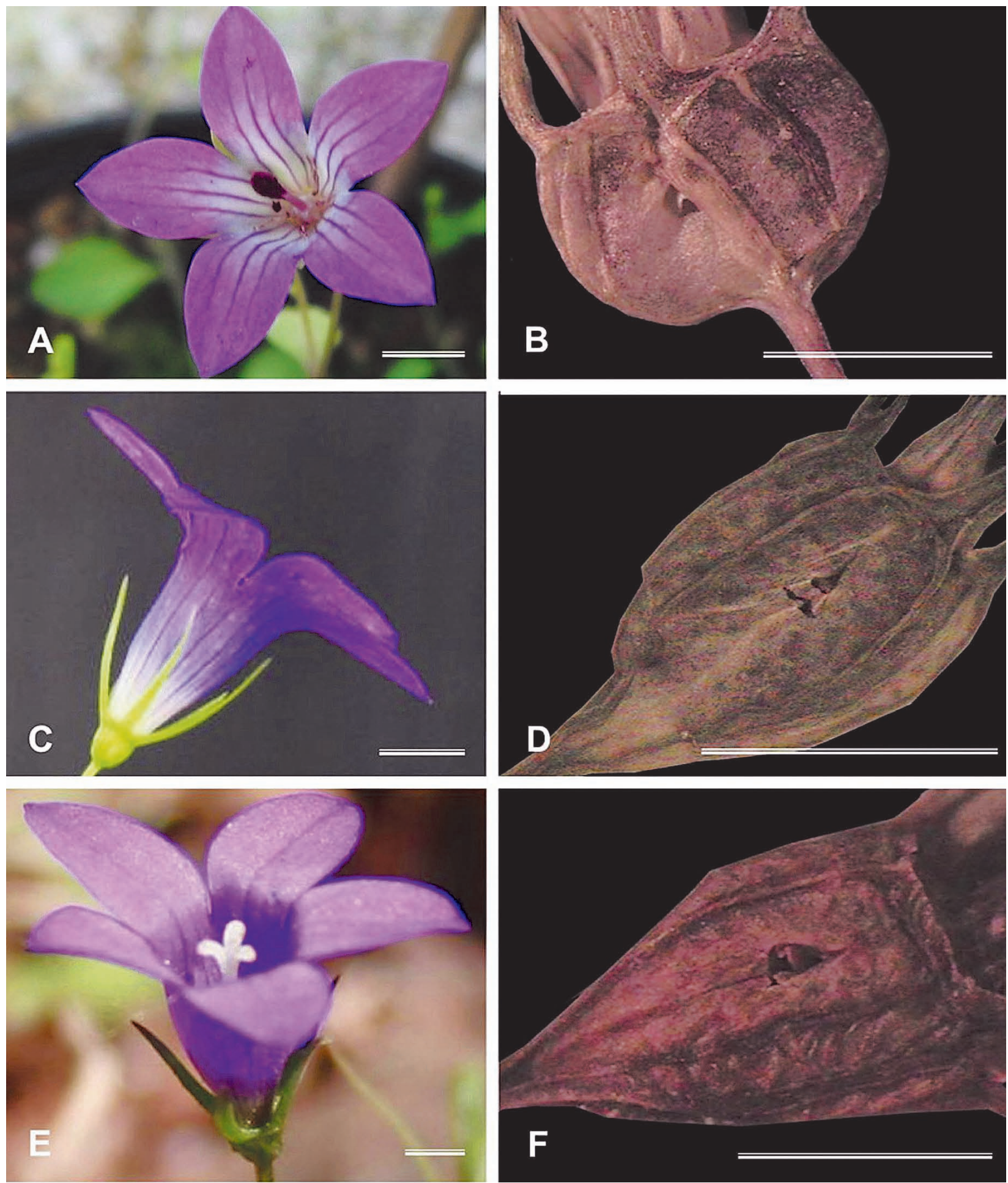

Fig. 10. Flowers and fruits of Campanula species. A, B, C. specularioides (Montejaque, Málaga, Spain, SEV 218871); C, D, C. transtagana (Valverde del Camino, Huelva, Spain, SEV 216212); E, F, C. broussonetiana (Jbel Tazzeka, Taza, Morocco, SEV 216476). The scale bar $=3 \mathrm{~mm}$. 
and stigmas, and in the indumentum of calyx and capsule. since both can be very hairy or completely glabrous, even in the same population, although more commonly all plants of a population have glabrous calyx, and likewise the capsule. Within populations there are plants with white anthers and stigmas, and others with blue anthers and stigmas, or even plants with white anthers and blue stigma or vice versa. All these colour morphs, which certainly have a genetic basis, seem to be interfertile so this trait has little taxonomic value. Based on the middle position of the pores in the capsule, this species was included by Fedorov (1976) in the sect. Campanula. The phylogenetic tree of nr DNA ITS shows that $C$. transtagana and C. broussonetiana are sister species of $C$. specularioides (see Fig. 1).

The type material of $C$. specularioides consists of three complete plants and several fragments. The largest of the three plants, placed at the top of the sheet was chosen as lectotype, since it is consistent with the description of E. Cosson (see Fig. 9). In the general herbarium of the "Conservatoire et Jardín Botanique de Genève" there is a sheet (G 104263) with several plants of the same collection of E. Bourgeau, that are also possible type materials.

\section{Selected spcimens}

SPAIN. Cádiz: Benaocaz, Km 16-17 a Ubrique, 22-VI-1984, $A$. Aparicio E J. G. Rowe (MA 490917, SEV 161738). Entre Benaocaz y Ubrique, 13-VII-1978, J. Devesa \& al. (MA 465708, MA 111772, SEV 103546). Entre Ubrique y Grazalema, 13-VI-1970, E.F. Galiano E B. Valdés (SEV 108955). Entre Villaluenga del Rosario y Benahocaz, 26-VI-1988, Férnandez Díez \& Mochales (SALA 47474, MA 476540). Grazalema, 21-VI-1890, E. Reverchon, in E. Reverchon, Plantes de L' Andalousie, 1890: no 331 (G 104191). Idem, 9-VII-2003, J. Cano-Maqueda (SEV 216211). Cerro de San Cristóbal, V-1961, J. Borja (MA 177095, SEV 5016). Manga de Villaluenga, 22-VI-1983, A. Aparicio \& J.G. Rowe (SEV 161737). Sierra de la Silla, 21-VI-1983, A. Aparicio \& S. Silvestre (G 104188, MA 490918, SEV 161731). Sierra de Zafalgar, Puerto de la Miera, 28-VI-1984, A. Aparicio \& al. (SEV 161726). Sierra del Caillo, Navazo Alto, 30-VI-1983, A. Aparicio (SEV 161730). Sierra del Endrinal, Pozo de las Presillas, 12-VII-1984, A. Aparicio \& S. Silvestre (SEV 161736). Ubrique, 26-VI-1925, P. Fonti Quer \& E. Gros (MA 702195, MGC 53268, SALA 114797). Villaluenga del Rosario, 24-VI-1973, A. Asensi \& B. Diez (MGC 81). Málaga: Benaoján, 17-VI-2007, J. Cano-Maqueda (SEV 218871). Cartajima, Cancha Almola, 12-VI-2004, O. Gavira (MGC 60974, MGC 60975). De Ronda a Montejaque et circa Cueva de la Pileta, 17/18 VI-1972, L. Bernardi (G 104194, MA 269887). Jimera de Líbar, Alto del Conio, 4-VII-2004, O. Gavira (MGC 60868). Montejaque, 8-VI-2005, J. Cano-Maqueda (SEV 216210). Serranía de Ronda, 23-VII-1888, E. Reverchon, in E. Reverchon, Plantes de L'Andalousie, 1889: no 331 (G 104264, G 104185, G 104186, G 104187, G 104192, G 104193, LISU 50130, MA 121476, MA 121477).

5. Campanula transtagana R. Fern. in Bot. Soc. Brot. ser. 2, 36: 121-126. 1962
C. lusitanica subsp. transtagana (R. Fern.) Fedorov in Bot. J. Linn. Soc. 67: 281. 1973. Ind. loc.: "Habitat in Lusitania, regione Transtagana, ad marginem sinistram fluminis Tagis pr. pagum dictum Vila Velha de Ródâo, ubi super declives solo argilloso et sicco inter sepes copiosa, 21-VI-1959, A. Fernandes, J. Matos \& A. Sarmiento 2923 (COI, holotype)", (Fig. 11; see observations).

C. loeflingii var. filiformis Lange in Vidensk. Meddel. Dansk. Naturhist. Foren. Kjøbenhavn 1861: 108. 1862. Ind. loc.: "La Carolina (Sierra Morena) 10 Mai.". Type : not found in the Lange herbarium (C).

\section{Illustrations: Fig. 10 C, D.}

Herb 6-45 cm, annual, decumbent or erect, branched from the base, rarely in the upper half, very laxly pubescent, not brittle. Stems angled, branched, glabrescent, with hairs 0.1-0.2, commonly very laxly located in the stem angles. Leaves not coriaceous, crenate, entire or toothed, petiolate; middle cauline leaves (4.6)9-20(30) × 2.2-8(13.2) mm, elliptic, laxly pubescent, with hairs $0.1-0.3 \mathrm{~mm}$ scattered over the limb and margin of the leaf, and with petiole 0.2-4.5

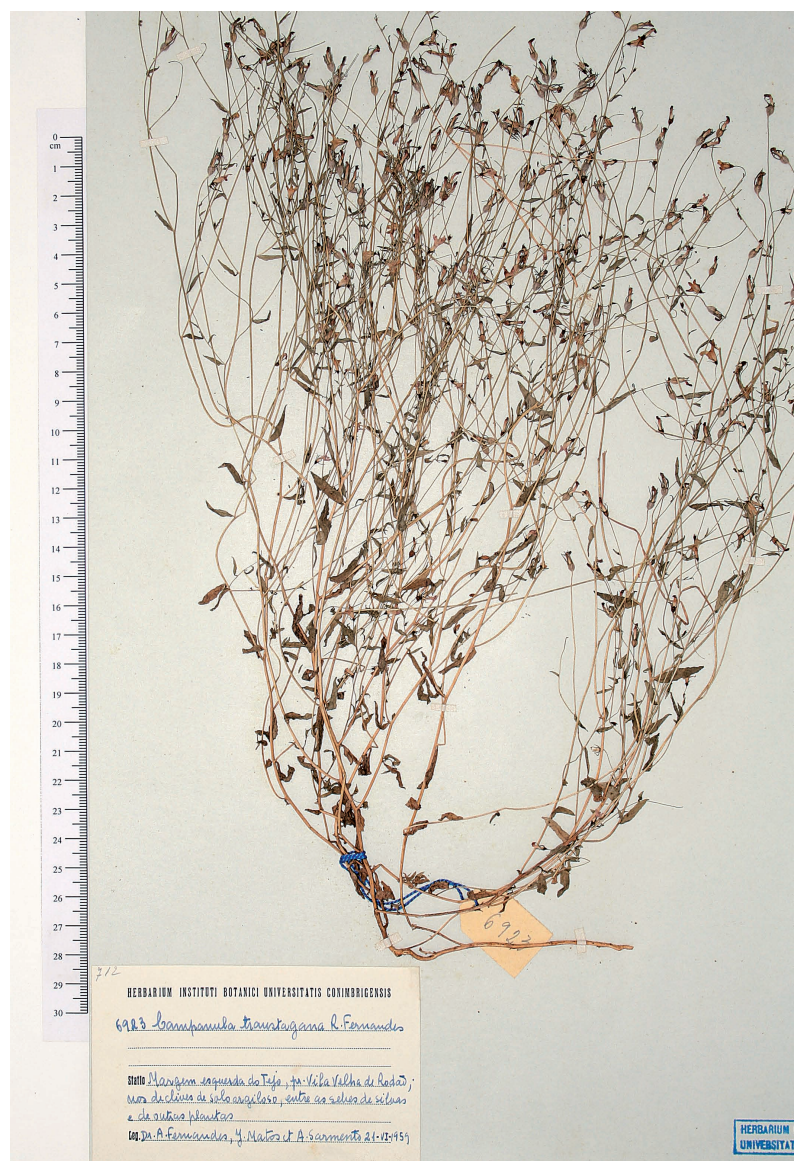

Fig. 11. Holotype of Campanula transtagana (COI). 
$\mathrm{mm}$; upper cauline leaves (3)5-11(15) $\times$ 0.6-3.4 mm, elliptic, laxly pubescent, with hairs $0.1-0.3 \mathrm{~mm}$ scattered over the limb and leaf margin, and with petiole $0.2-0.3 \mathrm{~mm}$. Inflorescence laxly paniculate. Flowers pedicellate; pedicel $9.6-64 \mathrm{~mm}$, glabrous or with some hairs of c. $0.5 \mathrm{~mm}$. Calyx-teeth (2.9)3.5-16.6 × 0.3-0.7 $\mathrm{mm}$, linear. Corolla (6.5)8-12(14) mm, campanulate, with the tube greater or equal, rarely shorter, than the lobes; tube (2.9)3.7-7 mm, light blue with a white base; lobes 3.6-7 × 2.2-3.5 mm, elliptic, bluish. Stamens with enlarged base of 0.5-1 × 0.3-0.6 mm; filaments $0.2-0.6 \mathrm{~mm}$; anthers $1.6-2.7 \mathrm{~mm}$, whitish. Ovary glabrous, rarely with setose hairs 0.1-0.2 mm; style 4.5-6.4 mm, hairy in the upper half; stigma trifid, with estigmatic branches $0.6-1.2 \mathrm{~mm}$, patent, curved, white. Capsule 2-4.4 × 1.5-3 mm, subovoid or subspherical, longer than wide, glabra, rarely with some setose hairs of 0.1-0.2 mm, with 10 angled nerves, but not winged, dehiscing by three pores of middle or subapical position. Seeds 0.4-0.6 $\times 0.1-0.2 \mathrm{~mm}$, ovoid, shining, yellowish to brown. $2 n=20 ; n=10$.

Habitat, phenology and distribution: Wet grasslands on sandy or slate-rich substrates; $50-800 \mathrm{~m}$. V-VI (VII). • Endemic to SW Iberian Peninsula, from the River Tajo to the Guadiana, Sierra de Guadalupe and almost all Sierra Morena (Fig. 12). Portugal: AAl Ag BAl BB. Spain: Ba Cc Co H J Se.

Observations: C. transtagana is rare in Portugal and in Sierra de Guadalupe but very common throughout the Sierra Morena, especially in shady slopes and valley bottoms, where it normally co-habits with C. matritensis. The profuse branching, small corollas with white background tube and petiolate leaves of the stem, clearly differentiate it from $C$. matritensis.

The holotype of $C$. transtagana consists of five cultivated plants that are very branched from the base, between 20 and $35 \mathrm{~cm}$, and placed on three sheets in Coimbra herbarium.

\section{Selected specimens}

PORTUGAL. Algarve: Serra da Picota, VII-1891, J. Brandeiro (COI). Alto Alentejo: Redondo, V-1892, A. Fernandes \& al. (COI). Idem, VI-1893, A. Fernandes \& al. (COI). Riveira da Sapatoa, a $5 \mathrm{~km}$ de Montoito e a 16 de Reguengos de Monsaraz, 10-VI1962, A. Fernandes \& al. (COI). Baixo Alentejo: Concelho de Moura, margens do rio Guadiana, 2-IV-1999, P. Bringe \& T. Rego, in Exsiccata Flora Iberomacaronesica Selecta, centuria IV: $\mathrm{n}^{\circ} 340$ : (FCO 25015, MA 632684, SALA 99329, SANT 42025). Entre Eiras Altas e Claúdia, 11-VI-1962, M. da Silva (LISE 76991, MA 199926). Margem da ribeira de Chança, prox. Vila Verde de Ficalho, 11-VI-1962, A. Fernandes E al. (COI). Beira Baixa: Encosta da margem esquerda do Tejo, entre a estrada e o rio Tejo, 8-VI-1962, A. Fernandes $\&$ al. (COI). Salvaterra do Extremo, 14-VI-2005, $A$. Charpin (G 104159).

SPAIN. Badajoz: Don Benito, La Zafrilla, 28-VI-1985, M.J. Gallego (SEV161715). Magacela, El Berrocal, 25-V-2001, P. Esco- bar García (MA 707042). Oliva de la Frontera, riberas del río Ardilla, 23-IV-1994 VI itinera Mediterranea no 557 (MA 717195). Cáceres: Guadalupe, 31-V-1958, E. Guinea (MA 432639). Córdoba: Alcolea, margen derecha del Guadalquivir, 21-V-1987, Z. Díaz E C. López (SEV 130952). Cardeña, 24-VI-2005, J. Cano-Maqueda E al. (SEV 216480). Entre Azuel y el río de las Yeguas, 28-V-1982, J. Devesa E García (SEV 161896). Entre Montoro y Adamuz, proximidades a Montoro, 4-V-1982, M.J. Diez E I. Fernández (SEV 161898). Río Zújar, cruce con la carretera Los BlázquezPeraleda de Zaucejo, 6-VI-1979, J.M. Muñoz E E. Ruiz de Clavijo (SEV 161897). Trassierra, derecha del Guadiato, Cerro del Trigo, pantano de la Breña, 16-VI-1978, J.A. Varela (SEV 161900). Villafranca, central eléctrica, río Guadalquivir, 21-V-1987, Z. Díaz E C. López (SEV 130876). Huelva: Alosno, 26-V-1942, C. Vicioso (MA 121571). Aracena, entre la Cefiña y la N433, 23-V-2005, J. Cano-Maqueda E al. (SEV 216213). Corterrangel, 18-VI-1978, J. Rivera (SEV 48336). Entre Aroche y Las Cantiendas, 6-VI-1979, J. Rivera E B. Cabezudo (MGC 8832, SEV 48900). Escacena del Campo, Reserva de la Pata del Caballo, arroyo del Chacho, 31-V-2001, B. Cabezudo \& al. (MGC 48565). Higuera de la Sierra, 400 m, 24-V-1988, E. Bayón E E. Villanueva (MA 438691). Linares de la Sierra, 22-VI-1942, C. Vicioso (MA 121570). Río Múrtiga, 8-VI-1984, F.J. García Ev al. (G 104154). Valverde del Camino, El Manzanito, 23-V-2005, J. Cano-Maqueda (SEV 216212). Jaén: Andújar, Arroyo de los Santos, 22-VII-1992, J.M. Mancebo (MA 651609). Baños de la Encina, Charca de la Enea, 29-VII-1992, J.M. Mancebo E J.R. Molina (MA 651610). Despeñaperros, 1-VII-1975, J. Fernández Casas E al. (MA 412612). Sevilla: Castilblanco de los Arroyos, 1-VI-2006, J. Cano-Maqueda E al. (SEV 232786). El Castillo de las Guardas, V-1914, C. Vicioso (MA 121569). El Garrobo, junto a la carretera, 15-V-1982, J.M. Rodríguez E al. (SEV 161950). Entre el Ronquillo y Almadén de la Plata, 22-VI-1976, E.F. Galiano (SEV 161899). Guillena, Arroyo Herrero, without date, C. Fernández \& J.A. Fariña (SEV 109874).

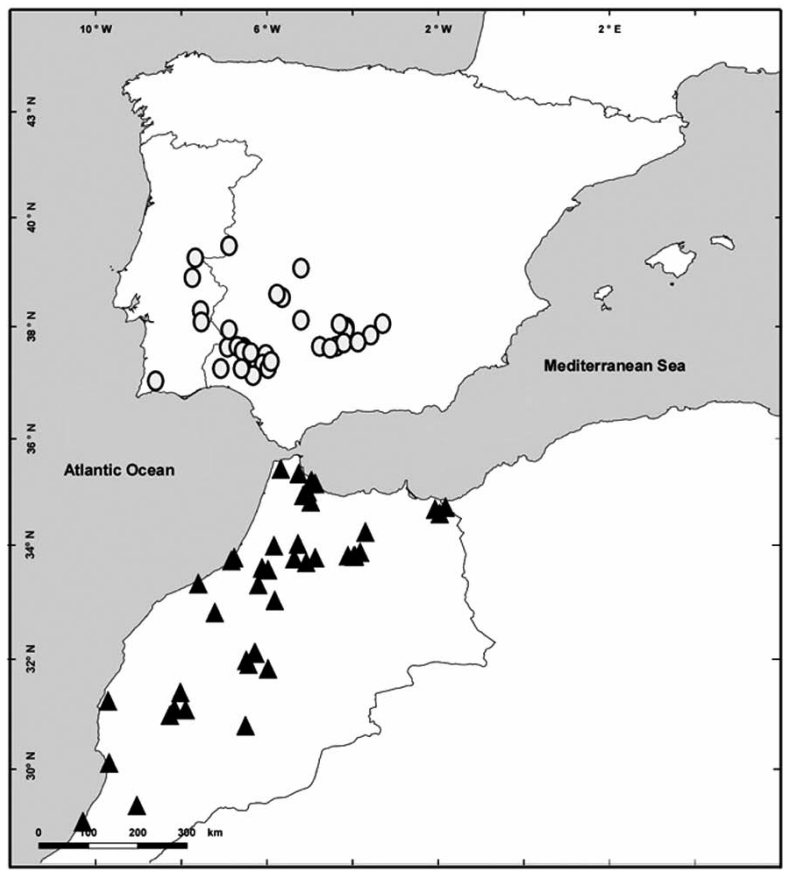

Fig. 12. Distribution map of Campanula transtagana $(\bigcirc)$ and C. broussonetiana $(\mathbf{\Lambda})$. 
6. Campanula broussonetiana Schult. in Roem. \& Schult., Syst. Veg. 5: 104. 1819-1820

C. lusitanica var. broussonetiana (Schult.) Pau in Mem. Real Soc. Esp. Hist. Nat. 12: 356. 1924. Ind. loc.: "In Mogador. Broussonet". Type: Morocco. Safi, Mogador, Broussonet s.n. (lectotype: here designated, W 03798!; see observations).

C. loeflingii var. maura Murb., Contr. Fl. Maroc. 2: 50. 1923. Ind. loc.: "Pentes herbeuses entre Amismiz et Oucheffine; Ighen Draa près Demnat. 900-1000 m.- J'ai vu la même plante des environs de Casablanca (leg. Mellerio)". Type: not studied.

C. Lusitanica f. pallidiflora Maire in Jahand. et Maire, Cat. Pl. Maroc: 735. 1934. Ind. loc.: "Mont Tazzeka (Humbert et Maire)". Type: not studied.

C. lusitanica $\mathrm{f}$. tenuis Caball. in Trab. Mus. Ci. Nat. Madrid, Ser. Bot. 30: 5. 1935. Ind. loc.: "Legi basi montis Tamarrut dicto, 6-VII-1934”. Type: Morocco. Agadir, Tamarrut, 6 July 1934, Caballero s.n. (lectotype, here designated, MA 121492!; see observations).

C. vincaeflora Pau in Bol. Soc. Esp. Hist. Nat. 21: 278. 1921, nom. illeg., non Vent. 1804. Ind. loc.: "Tiguisar, 26-IV[-1921]”. Type: Morocco. Tittáguen, Tiguisar (Gomara), 26 April 1921, Vidal López s.n. (lectotype, here designated, MA 121493!; see observations).

\section{Illustrations: Fig. 10 E, F.}

Herb 6-45 cm, annual, erect or decumbent, branched from the base, pubescent, not brittle. Stems angled, branched, pubescent, rarely glabrous at the apex, with long hairs up to $0.4-2 \mathrm{~mm}$. Leaves scarcely coriaceous, crenulated, entire or toothed; middle cauline leaves 8-37 × (4)6-15.5 mm, broadly elliptical or obovate, sessile and cuneate or with petiole up to 2 $\mathrm{mm}$ and rounded at the base, entire or toothed, $\pm \mathrm{pu}$ bescent, with hairs up to $1.2 \mathrm{~mm}$; upper cauline leaves (4.2)6-13.5 × 1-7.6 mm, elliptical or lanceolate, generally entire, sessile, cuneate, pubescent, with hairs up to $0.4 \mathrm{~mm}$ or rarely glabrous, without a differentiated petiole. Inflorescence laxly paniculate. Flowers pedicellate; pedicel 7-67 mm, glabrous or with hairs 0.2$1.2 \mathrm{~mm}$. Calyx-teeth (3.6)5.2-13.5 × (0.4)0.7-2(2.7) $\mathrm{mm}$, oblanceolate, rarely linear. Corolla (7.2)8.8-17 $\mathrm{mm}$, campanulate, with the tube usually shorter or equal in length to the lobes, rarely longer than lobes; tube 4,1-8,3 mm, with the base whitish and the apex light blue; lobes (2.4)3.5-8 × 2.1-5,2 mm, ellipticlanceolate, bluish. Stamens with enlarged base of 0.6$0.7 \times 0.4-0.6 \mathrm{~mm}$; filaments $0.6-0.7 \mathrm{~mm}$; anthers $2.1-4$ $\mathrm{mm}$, bluish or white. Ovary glabrous, rarely with hairs 0.1-0.8 mm; style 5-8.2 mm, hairy; stigma trifid, with stigmatic branches of 1-2 mm, patent, curved, white or blue. Capsule 3-6.6 × 2-4.1 mm, subovoid, longer than wide, glabrous, rarely with setose hairs, with 10 nerves \pm angled but not winged, dehiscing by three subapical pores. Seeds 0.4-0.6 $\times 0.2-0.3 \mathrm{~mm}$, ellipsoid, shining, yellowish to brown. $2 n=20$.

Habitat, phenology and distribution: Shady hollows and the understory of cork woodlands, on limestone, or slate-rich or sandy substrates, from sea level to high mountains; 0-2000 m. IV-VII(VIII). • Endemic to W and $\mathrm{N}$ Morocco, along most of the Atlantic coastlands from Sidi Ifni to the Mamora forests; also the Rif, Middle Atlas and Great Atlas (Fig. 12).

Observations: This species has the same color morphs for anthers and stigmas as those found in C. specularioides, and similary, the morphs seem to be interfertile. Alphonse De Candolle (1830) synonymized this species with $C$. loeflingii Brot., possibly influenced by the illustration 18 of the "Phytographia Lusitaniae Selector" (Brotero, 1816) under this name. Certainly, C. lusitanica and C. broussonetiana are very similar morphologically. Both have long hairy indumentum that is straight and patent on the stem, and wide leaves, but in C. broussonetiana the middle cauline leaves are attenuate at the base or petiolate and in C. lusitanica are sessile and subauriculate. The molecular phylogeny has shown that $C$. broussonetiana is more closely related to $C$. transtagana than any other species of sect. Rapunculus (see Fig. 1).

The sheet of type material of C. broussonetiana (W03798) contains a complete highly branched plant with many flowers. Schultes (1819-1820: 104) already indicated that the type material was in the Willdenow herbarium under the name Campanula ramosissima. In the herbarium of the Prodromus of De Candolle there are two sheets (G 138472 and G 138271$G$ 138478), one (G 138472) with a complete plant of c. $30 \mathrm{~cm}$ and the other (G 138271, G 138478) with three smaller plants $(15-22 \mathrm{~cm})$, all belonging to the expedition by Broussonet in 1804, collected at Mogador (Essaouira, Morocco). This last sheet contains two labels. In one (G 138478), handwritten by A. De Candolle, is indicated "Voyage de Broussonet 1804" at the base of two of the plants, and in the other $(\mathrm{G}$ 138271), with orthography of Broussonet, is written: "Campanula/Mogador" and also, with orthography of Alphonse De Candolle, "Campanula loeflingii Brot./_ Broussonetiana Roem. Et Sch./ A. DC.”. These materials were probably not studied by Schultes, and therefore they can not be considered type material (Fig. 13).

The sheet of type material of $C$. lusitanica $\mathrm{f}$. tenuis contains two complete plants with flowers in postan- 
thesis and two single flowered small stems. The larger sized plant $($ c. $20 \mathrm{~cm})$ is chosen as lectotype. The sheet also contains three determinavit labels, one handwritten by C. Pau, which reproduces all the information of the name, the diagnosis and the protological description from Caballero; the second label was identified as C. lusitanica by Yvonne Nyman in 1987 and the third label by Juan José Aldasoro and Llorenç Sáez who identified the specimen as $C$. broussonetiana

The type material of $C$. vincaeflora consists of a single whole plant in flower that we have chosen as lectotype. The sheet contains some other stems and a label printed with the original description.

\section{Selected specimens}

MOROCCO. Agadir: Col du Kerdous (Anti-Atlas), 26-V1980, A. Charpin \& al. (G 104179, MA 227542). Ida Ouehembal, Sud-ouest du Maroc, 1875, Mardochée (G 104254, G 104168, G 104255). O. Querat, Sous, 29-IV-1923, E. Jahandiez, in E. Jahandiez. Plantes Marocaines, 1923: nº 211 (G 104173). 3 Km Sidi Ifni, 16-IV-1989, F. Jacquemoud (G 104160). Beni Mellal: entre le

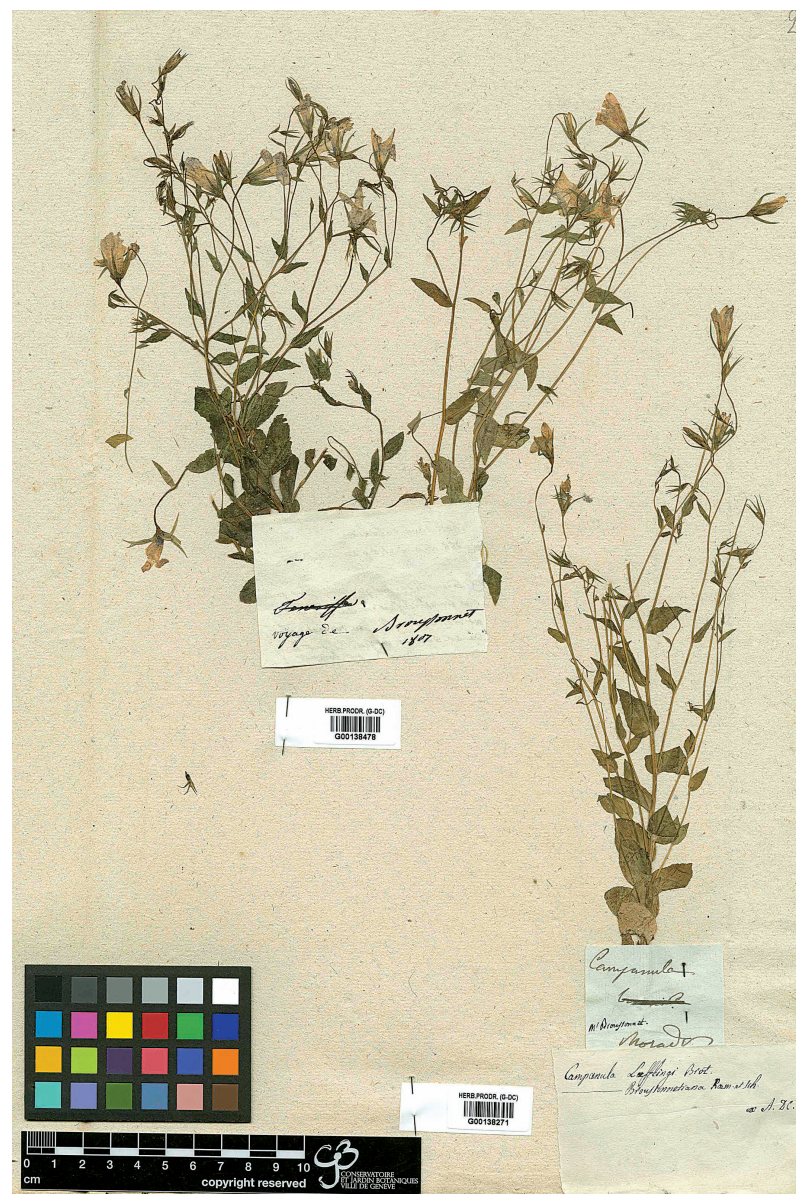

Fig. 13. Materials of Campanula broussonetiana. Collected by Broussonet in Mogador (Essaouira, Morocco) during his campaign in Morocco in 1805. The type material of this collection is located in Willdenow herbarium (B).
Col du Tizi Mlil et Beni Mellal, 5-VI-1980, A. Charpin E al. (G 104180, MA 243114). Entre Oulad M' Barek y Ouaouizarhte, cerca de Beni Mellal, 12-VI-1982, J. Fernández Casas E al. (MA 633188, MA 430482). Gran Atlas, entre Afourer y Bin-el-Ouidane, 9-VII-1996, S. Cirujano \& al. (MA 625034). Subida al Jbel Tassemit, 23-IV-2003, S. Talavera E al. (SEV 216216). Dar el Beïda: Sidi Abd-Er-Rahman, 1886, Ibrahim (G 104250). El Jadida: 20 Km NE Benahmed an der Strase nach El-Khatouat (1419), 6-V1989, D. Podlech (G 104182). Er Ribat: Arbaa-Sehoul, en la carretera hacia Romani, 2-V-2007, S. Talavera E al. (SEV 224279). Fes: subida a Jbel. Zalagh, al NE de Fes, 16-V-2006, S. Talavera \& al. (SEV 217539, SEV 217537, SEV 217536, SEV 217535, SEV 217534). Bab Zitouna, collado del Jbel Zalagh, en la ruta de Fes a Ouezzane, 10-V-1994, A. Achbal \& al. (SEV 161661). Jbel Zalagh, al NE de Fes, 17-V-2006, S. Talavera E al. (SEV 216499). Kenitra: entre Sidi-Slimane y Khemisset, en saladares, 9-IV-1983, J.A. Devesa $\mathcal{E}$ al. (SEV 161658). Forèt de la Mamora, entre Khemisset y Tiflet, a la izquierda en dirección a Máaziz, 25-V-2006, S. Talavera E al. (SEV 234710). Mamora, Dar Salem, sables, 29-IV-1924, E. Jahandiez, in E. Jahandiez, Plantes Marocaines, 1924: $\mathrm{n}^{\circ} 211$ (G 104174, MA 121503). Montes de Zaïan, entre Tiddas y Jbel, Bouchchene, 24-V-2006, S. Talavera E al. (SEV 234709). Salé, 25IV-1888, Grant (G 104251). Marrakech: cerca de Toufliht, entre Marrakech y Taddert, 14-VI-1982, J. Fernández Casas É al. (MA 430483). De Marrakech a Oukaimeden, Ogaionar, a $53 \mathrm{~km}$ de Marrakech, 1-VI-2007, S. Talavera E al. (SEV 223071). Gran Atlas, V-1871, Hooker (LISUG 50012). Krifla, 16/18-IV-1887, Grant (G 104167). Medna Ben Abou, 11-IV-1921, G. Wibagek (G 104175). Tabgourt, 20-VII-1884, Ibrabim (G 104259). Sidi-Ouasmin, 12-VI-1889, Ibrabim (G 104252). Meknés: Atlas Medio, entre Oulmés y Aguelmous, 24-V-2006, S. Talavera E al. (SEV 234711). Entre Meknés et Fes, $2 \mathrm{Km}$ avant le croisement à Ain Taoujdate, 15-V-1989, B. Valdés É al (SEV 161657). Zerhoun, c. $25 \mathrm{Km}$ due NE of Meknès road from Moulay Idriss to Nzaia-desBeni-Ammar, 5-VI-1994, S.L. Jury, M. Ait Lafkib \& B. Tahiri (SEV 161660). Oudjda: Berkane, Refuge Zegzel, 23-V-1928, A. Faure (G 104165). Env. de Martimprey-du-Kiss, Pelouses et broussailes, 14V-1930, A. Faure (G 104177, G 104166, MA 121481). Monts des Beni-Snassèn, Djbel Fourhal, près de Taforalt, 23-V-1994, J. Lambinon \& G. Van Den Sande (MA 562384). Safi: environs de Mogador, 1867, B. Balansa (G 104253). Falaises da Cap Safi, 17-IV1924, in E. Jahandiez, Pl. Maroc. 1924: no 82 (MA 121482). Mogador, 1804, Broussonet (G 138271, G 138472, G 138478). Tandja: Chaouia, 25-IV-1935, Gattefossé (G 104163). Taza: c. $32 \mathrm{Km}$ from Taza on minor road near Bab-Bou-Idir, 6-VII-1993, S.L. Jury E al. (SEV 161656). $11 \mathrm{Km}$ from Taza on minor road below RasEl-Ma, 4-VII-1993, M. Ait Lafkih \& al. (MA 577072, SEV 161659). Entre Bab-Azhar y Bab-Bou-Idir, 17-VI-2003, S. Talavera \& al. (SEV 216476, SEV 216478). Entre Sidi-Abdallah-desRhiata y Bab-Azhar, 17-VI-2003, S. Talavera E al. (SEV 216475). Tittáguen: Armautah, lower part of Jbel Bouhalla, 3-VII-1993, J.A. Mejías \& S. Silvestre (SEV 139107). Bou-Ahmed, pista entre Souk-el-Had e Imazerdane, 29-IV-1995, M.A. Mateos E al. (SEV 139102). C. Iaarguit ( Beni Hosmar), 26-V-1930, Font Quer, in Font Quer, iter maroc. 1930: n 637 (G 104162, MA 121489). Entre Bou-Ahmed y Targha, 3-V-1996, M.A. Mateos \& al. (SEV 155222). Kaa Asras, Imarsboutene, 5-V-1996, M.A. Mateos E al. (SEV 155672). Oued-el-Kannar, 7-VI-1930, Font Quer (SEV 139142). Oued Laou, 9-IV-1995, A.J. Caruz \& al. (SEV 139100). $\mathrm{SE}$ of Chefchaouen, E of Bab Taza, on road from Cherafat to Bab Berred, Matrasse Lakhmasse, 28-V-2002, M. Ait Lafkib E al. (MA 698258). Sok-el-Jemis (Beni Selman), pr. Tiguisas, 7-VI-1930, Font Quer, in Font Quer, Iter Maroc., 1930: n 638 (G 104164, MA 121484). Talembote, $1 \mathrm{Km}$ vor dem Ort in Flussbett des Oued Talembote, zw. Tamarix u. Oleander, 7-VII-1971, M. Dittrich (G 104178, G 104172). Targha, 7-IV-1995, A.J. Caruz \& al. (SEV 
139141); ibidem, valle en la ladera W del Djebel Azenti, 8-IV1995, A.J. Caruz E al. (SEV 154716). Tarsif , próximo a OuedLaou, 30-IV-1995, M.A. Mateos E al. (SEV 139101). Tétouan, entre Chechaouen y Talembote, 31-V-1981, (MA 236533). Xauen, 14-V-1921, Font Quer, in Font Quer, iter maroc., 1928: n 391 (G 104161, MA 121483, MA 121502, MA 121491).

B. Sect. Decumbentes Cano-Maqueda \& Talavera, Sect. nov. DC.

Type (here designated): Campanula decumbens A.

Plantae annuae vel perennes. Sinus calycis exappendiculati. Corolla infundibuliformis. Antherae albae. Stylus glaber. Stigma tripartitum erectum vel erectopatens rectum album, in pagina abaxiali multos pilos pollen collectores exhibet, pagina adaxiali glabra in qua pollen germinat. Capsula obpyramidali vel ovata 5 angulari, poris tribus versus apicem vel subapicem sitis debiscente.

Annual or perennial plants. Without calycine appendages. Corolla infundibuliform. Anthers white. Style glabrous with a tripartite stigma. Stigma erect or erect-patent, straight, white, with numerous pollen collecting hairs on the abaxial surface, glabrous and receptive in the adaxial side. Capsule obpyramidal or ovoid, dehiscing by three apical or middle position pores.

Observations: This section consists of two species from the Iberian Peninsula (C. decumbens and C. dieckii), and two species from the Eastern Mediterranean (C. ramosissima and C. hawkinsiana). In the topology of the ITS tree (Fig. 1), this section forms a moderately supported clade (67\% PPS), where C. decumbens appears as sister of C. dieckii (63\% PPS), and C. ramosissima and C. hawkinsiana join into a well-supported subclade (99\% BS; 100\% PPS). This section thus includes both annual (C. decumbens, C. dieckii, C. ramosissima) and perennial (C. hawkinsiana) taxa, and also shows great variability in chromosome number: with $2 n=32$ in $C$. decumbens (in this work), $2 n=28$ in $C$. dieckii (in this work), $2 n=20$ in C. ramosissima (Damboldt \& Podlech, 1964) and $2 n=22$ in C. hawkinsiana (Contandriopoulos, 1964a). The morphological characters that define this section (glabrous style with three straight, erect or erectpatent stigmas) are very rare in the Campanulaceae, and only co-occur in Campanula sect. Pterophyllum Damboldt.

7. Campanula decumbens A. DC., Monogr. Campan.: 334.1830

C. patula var. decumbens (A. DC.) Cuatrec. in Trab. Mus. Ci. Nat. Barcelona 12: 441. 1929. Ind. loc.:
"Habitat in Hispaniâ propè Aranjuez ... [description]. Specimina numerosa apud dominum Delessert, in herbario Ventenatii vidi. Circâ Aranjuez in Hispania lecta fuerunt”. Type: Spain. Madrid. Aranjuez, 1827, Delessert s.n. [lectotype, here designated, G 138256! (G-DC), Fig. 14; see observations].

Herb 8(14)-38 cm, annual, decumbent or erect, branched in the upper half or from the base, glabrescent. Stems angled, branched only in the inflorescence, glabrous or with a few antrorse hairs 0.1$0.3(1.4) \mathrm{mm}$ long, often scabrid near the flowers. Leaves not coriaceous, entire, toothed or crenulate; middle cauline leaves 9(13)-28 × 4.7-10 mm, elliptic or lanceolate, petiolate or sessile, toothed or entire, glabrous or with some hairs 0.1-0.2 mm scattered on the underside nerves, and petioles up to 7-12 $\mathrm{mm}$; upper cauline leaves 3(5)-15 $\times(0.5) 2.5-8 \mathrm{~mm}$, elliptic or lanceolate, cuneate or shortly petiolate, glabrous or glabrescent, with some hairs 0.1-0.3 long on the

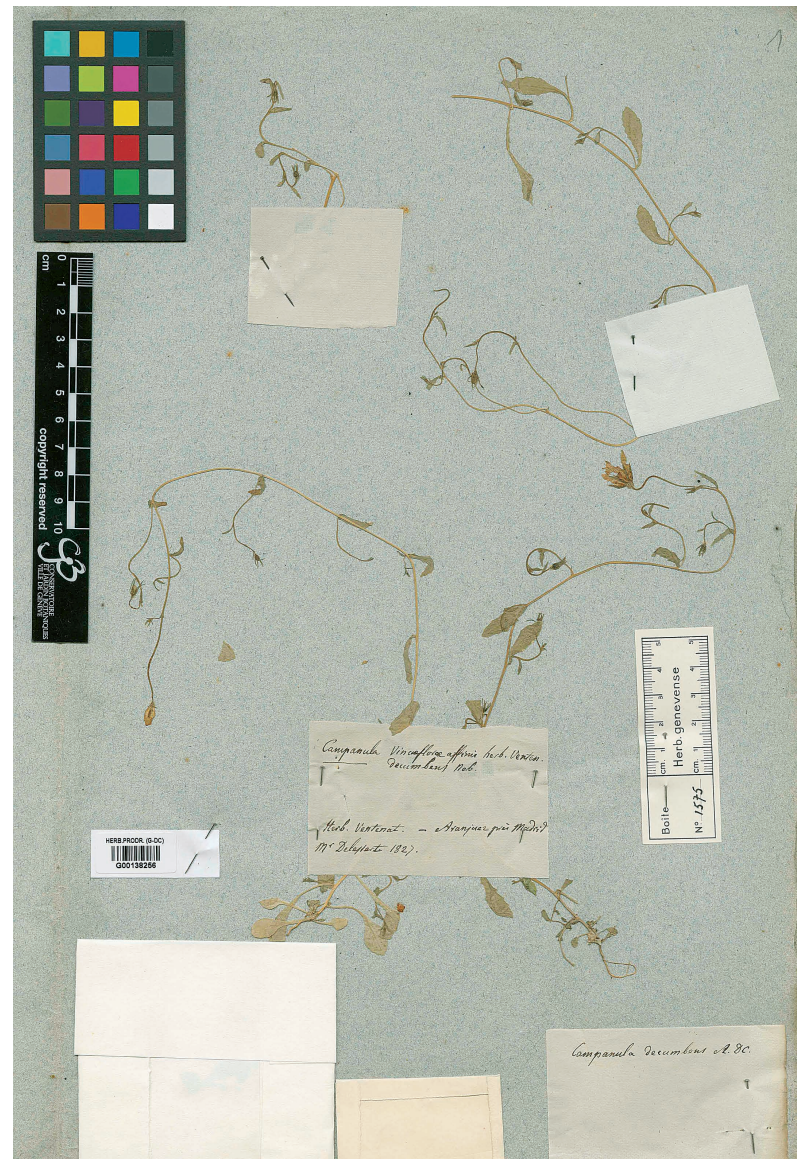

Fig. 14. Lectotype and isolectotype of Campanula decumbens ( $G$ 138256). The lectotype is the plant located in the center, on the right, the only one with a flower in anthesis. The other plants are isolectotypes. 
nerves of the underside, and petioles up to $2 \mathrm{~mm}$. Inflorescence laxely paniculate. Flowers pedicellate; pedicel (10.5)40-60(206) mm, glabrous or with some setose hairs near the ovary. Calyx-teeth (6)8-15 × 0.8$1.6 \mathrm{~mm}$, lanceolate or closely oblanceolate, with the apex obtuse or acute, entire. Corolla $12-21 \mathrm{~mm}$, infundibuliform, with the tube shorter than the lobes; tube 3-8 mm, light blue, with white base; lobes (7)9$10(14) \times 5-8.1 \mathrm{~mm}$, broadly triangular or elliptical, blue, with three darker nerves. Stamens with enlarged base of 0.7-1.5 × 0.5-1.5 mm; filaments $c .1 \mathrm{~mm}$; anthers 1.6-3(3.8) $\mathrm{mm}$, whitish. Ovary glabrous or papillose, rarely hairy; style (3)3.5-4(4.8) mm, glabrous, with 3 stigmas; stigmas (2)2.3-5(5.5) $\times$ 0.35-0.4 mm, erect-patent at anthesis, \pm straight, flat in the adaxial side, convex and with numerous pollen collecting hairs on the abaxial side. Capsule (2.2)3-8 × 2.4-4(5.7) $\mathrm{mm}$, ovoid or obpyramidal, longer than wide, glabrous or papillose, with 10 thick nerves, dehiscing by three apical or middle position pores. Seeds 0.4$0.7 \times 0.2-0.3 \mathrm{~mm}$, ovoid or ellipsoid, shining, brownyellowish. $2 n=32$.

Habitat, phenology and distribution: Grassland and wet meadows, on basic substrates (limestone and dolomite); 10-1250 m. VI-VII(VIII). • Endemic to the $S$ of Spain, in the Guadalquivir valley, Sierra de Grazalema and Serranía de Ronda, cited only once from Aranjuez. Spain: Ca M? Ma, Se.

Observations: The identity of $C$. decumbens has been discussed by various authors (Pau, 1896; Cuatrecasas, 1929; Caballero, 1942; Fedorov, 1976; LópezGonzález, 1979-1980); but in fact most authors do not treat with the decumbent plant from Aranjuez described by Alphonse De Candolle. These authors looked for this species near Aranjuez, but they only found an upright and very hairy plant with crenate leaves. This upright plant is the species described by Lange (1893) as C. dieckii and later by Pau (1896) as C. semisphaerica. Only Fedorov (1976) indicated that C. decumbens A. DC. is indeed decumbent. From the type he thought it endemic to Aranjuez, and that it might be better treated as subspecies or variety of C. patula L., as proposed by Cuatrecasas (1929).

The type material of Campanula decumbens $(G$ 138256) contains two complete plants of 20 and 25 $\mathrm{cm}$ and two stems, all with flower buds and only one plant with an open flower. This flowering plant is chosen as lectotype. The other materials are isolectotypes (see Fig. 14). In the general herbarium at Geneva there is another sheet ( $G$ 104141), also from the Ventenat herbarium, containing an incomplete plant of 20 $\mathrm{cm}$ with two flowers. The label indicates "Campanulal affinis vincaeflorae/ Aranjuez près Madrid". The plant contained in this sheet may also form part of type material.

The type material has petiolate middle leaves of the stem, and a small and infundibuliform corolla, in which it resembles C. cabezudoi [described by LópezGonzález (1979-1980) as C. decumbens var. pseudospecularioides]. But the style with three \pm straight stigmas is similar to that of $C$. dieckii and so, it is clear that $C$. decumbens A. DC. belongs to sect. Decumbentes. Cano-Maqueda \& al. (2008) indicated that this species, apparently only known only from the Delessert type materials, could be extinct. However, several populations have been located in Sierra de Grazalema and Serrania de Ronda, with the same characters as the type material of $C$. decumbens A. DC. Plants from two of these populations were cultivated in the greenhouses of the University of Seville. They retained the decumbent habit, are self-incompatible (Cano-Maqueda \& al., unpublished data) and the meiotic number of chromosomes is $n=16$.

Due to this discovery that $C$. decumbens occurs on diverse localities on alkaline substrates in the Serranía de Ronda and surrounding areas, it is likely that the material studied by Alphonse de Candolle came from the Southern Betic Cordillera and not from Aranjuez as stated in the sheet of the type.

Subsequently, a number of exsiccata by previous collectors in this area and also from the Guadalquivir valley and Cádiz coastland were also identified as $C$. decumbens. However, the Guadalquivir valley plants are morphologically rather different from those of the Sierras Béticas, although the molecular phylogeny has shown that both groups of plants do not present any changes in the nucleotide sequence (Fig. 1). They also have the same chromosome number $(n=16$; Table 1 and Fig. 2H). However, since in addition to the morphological differences, the populations present a different ecology and distribution, we have considered it most appropriate to treat these two groups of populations as two subspecies.

\section{KEY TO THE SUBSPECIES}

1. Middle cauline leaves petiolate; capsule (2.2)3-4(4.4) × 2,4-4 $\mathrm{mm}$, ovoid ............... a. C. decumbens subsp. decumbens

1. Middle cauline leaves sessile; capsule 4-8 × 3-5.7 mm, obpyramidal ................... b. C. decumbens subsp. baetica

a. Campanula decumbens A. DC. subsp. decumbens Illustrations: De Candolle (1830, tab. 12 fig. A); Fig. 15 A, B.

Herb 20-36 cm, decumbent. Middle cauline leaves petiolate. Calyx-teeth $(6) 8-10 \times 0.8-1.1 \mathrm{~mm}$, lanceolate, with the apex obtuse. Corolla 12-14 mm; tube 3- 

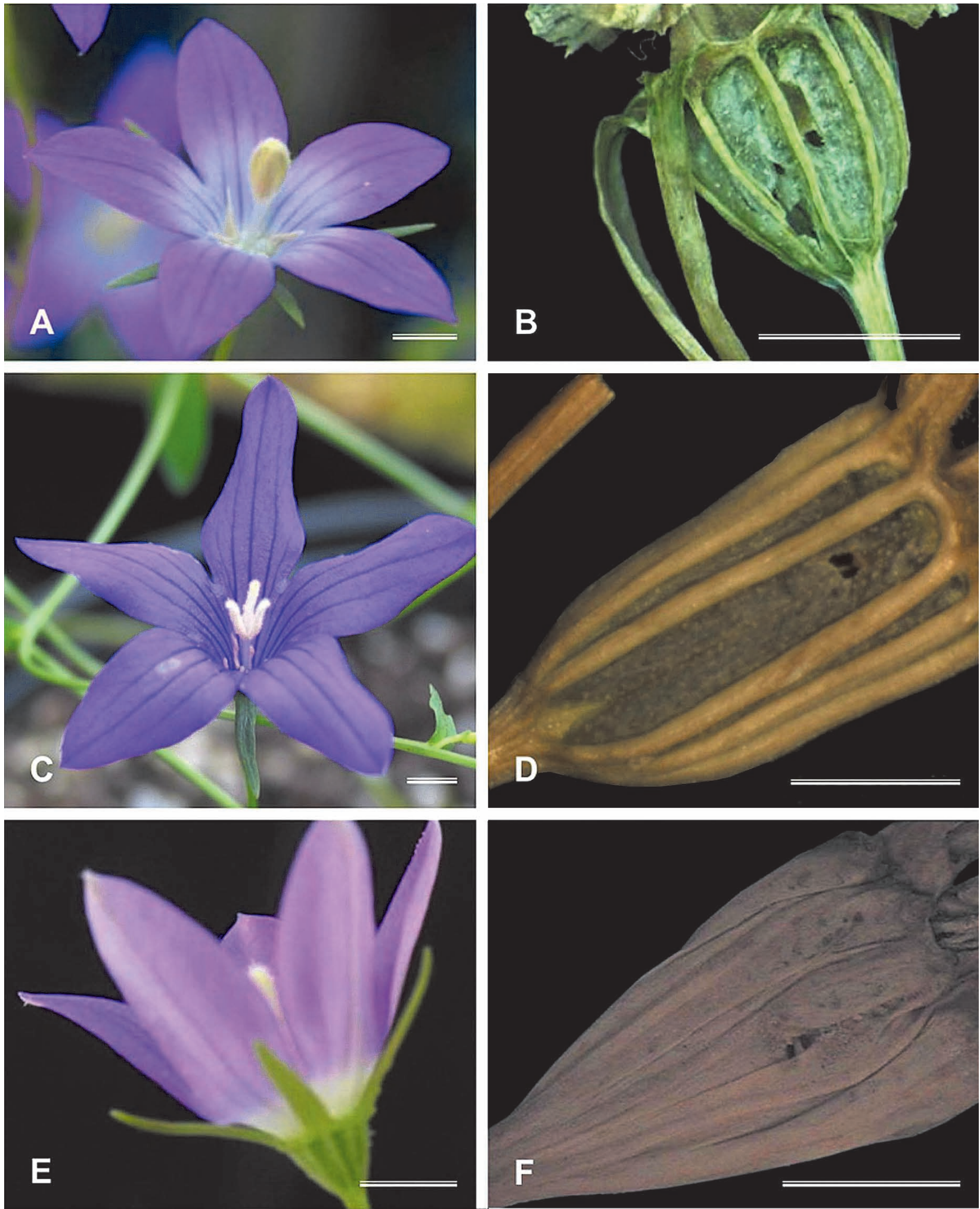

Fig. 15. Flowers and fruits of Campanula species. A, B, C. decumbens subsp. decumbens (Benaoján, Málaga, Spain, SEV 218875); C, D, C. decumbens subsp. baetica (Villamartín, Cádiz, Spain, SEV 256653); E, F, C. dieckii (Alfarnate, Málaga, Spain, SEV 256652). The scale bar $=3 \mathrm{~mm}$. 
$4 \mathrm{~mm}$; lobes 9-10 $\times$ 5-6 mm, broadly triangular. Stigmas 2-3.2 mm. Capsule (2.2)3-4(4.4) × 2.4-4 mm, ovoid. $2 n=32$.

Habitat, phenology and distibution: Wet meadows, on basic substrates (limestone and dolomite); (480) 1000-1250 m. VI-VII(VIII). • Endemic to the Sierra de Grazalema and Serranía de Ronda (Fig. 16). Spain: $\mathrm{Ca}$ M? Ma.

\section{Selected specimens}

SPAIN. Cádiz: Benaocaz, Manga de Villaluenga, 22-VI-1984, A. Aparicio \& S. Silvestre (SEV 161834). Grazalema, 11-VI-1890, E. Reverchon, in E. Reverchon, Plantes de 1 'Andalousie, 1889: $\mathrm{n}^{\circ}$ 17 (G 104066). Sierra del Endrinal, 10-VII-1925, Font $i$ Quer \& E. Gros (G 104158, MA 702573, MGC 53045); ibidem, 29-VI-1849, P. Fonti i Quer \& E. Gros (SALA 114817). Málaga: Benaoján, Carretera hacia Ronda, 15-V-1988, D. Montilla (MGC 40574); ibidem, Sierra del Palo, 17-VI-2007, J. Cano-Maqueda (SEV 218875); ibidem, 6-VI-2001, M. Becerra E al. (MGC 52844, MGC 51636); ibidem, Puerto España, 25-V-2002, M. Becerra \& F. Sánchez (MGC 51972). Ronda, 18-VI-1889, E. Reverchon, in E. Reverchon, Plantes de l'Andalousie, $1889 \mathrm{n}^{\circ} 17$ (G 104072).

b. Campanula decumbens subsp. baetica CanoMaqueda \& Talavera, subsp. nov.
A Campanula decumbens subsp. decumbens foliis caulinis sessilibus non petiolatibus, caule erecto non decumbente, capsula obpyramidali non ovata differt. A Campanula dieckii foliis glabrescentibus integris vel serratis, calyce, corolla stigmatibusque majoribus differt.

This subspecies differs from Campanula decumbens subsp. decumbens in its non-petiolate, sessile cauline leaves, erect rather than decumbent stems, and obpyramidal capsule, not ovoid. It differs of Campanula dieckii by its entire or toothed and glabrescent leaves, and by the larger size of the calyx, corolla and stigmas.

Type: Spain. Sevilla. El Coronil, bujeos, June 1990, Aparicio \& Silvestre s.n. (holotype: SEV 217838!, Fig. 17; isotype: SEV 238167!).

Illustrations: Boissier (1839, tab. 120a, as C. erinoides); Fig. $15 \mathrm{C}$ and D.

Herb (8)14-38 cm, erect. Middle cauline leaves sessile. Calyx-teeth (8)8.5-15 × 1-1.6 mm, closely oblanceolate, with the apex acute. Corolla (12)14.5-

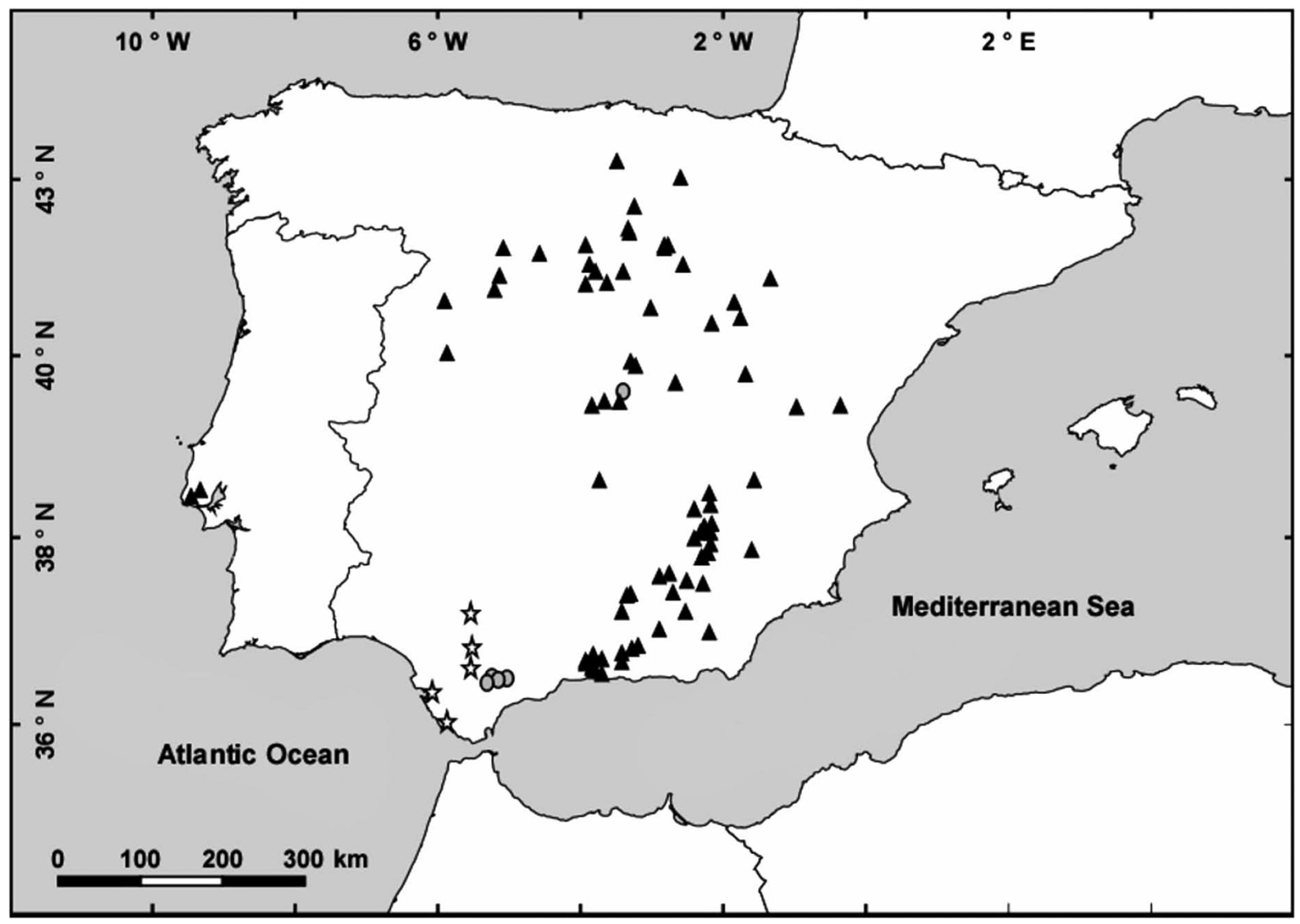

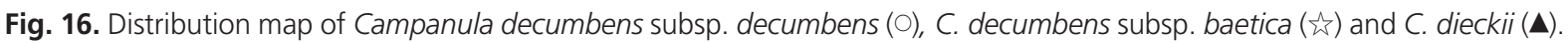




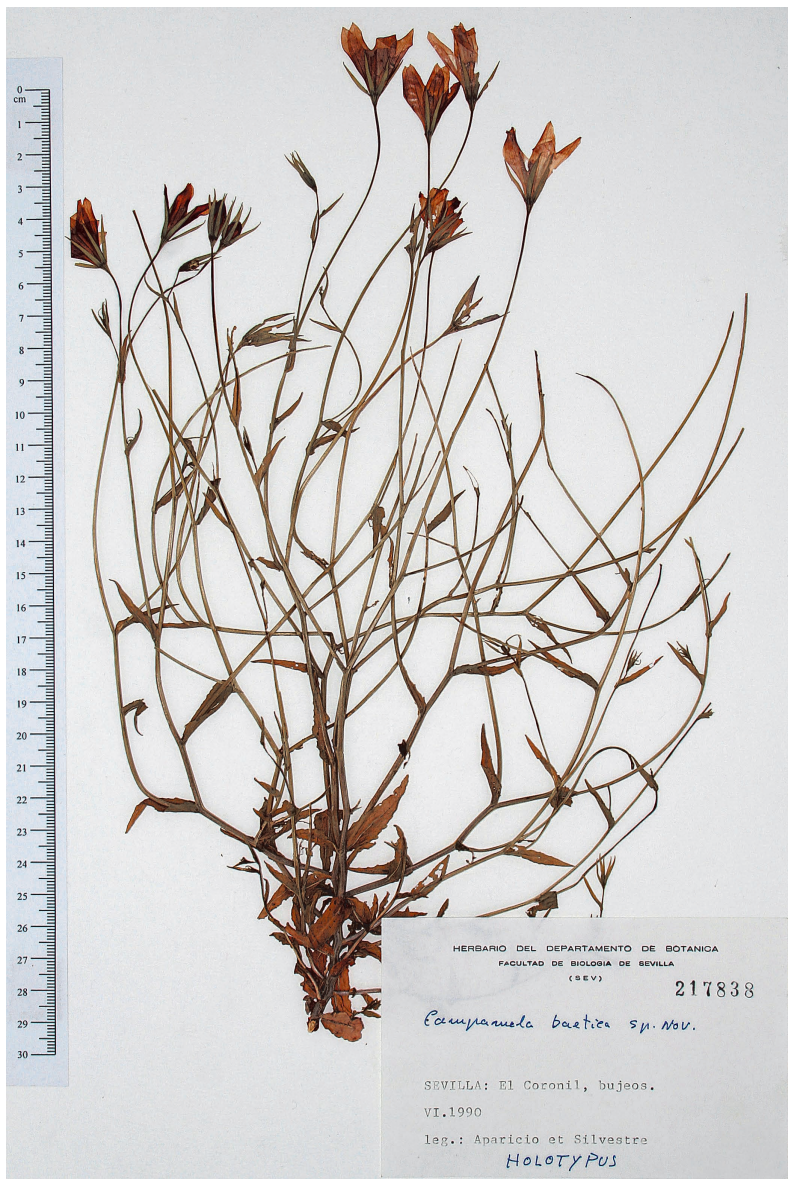

Fig. 17. Holotype of Campanula decumbens subsp. baetica Cano-Maqueda \& Talavera (SEV 217838).

$21 \mathrm{~mm}$; tube (3.4)4-8 mm; lobes 7-14 ×5-8 mm, elliptical. Stigmas (4)4.3-5.5 mm. Capsule 4-8 × 3-5.7 mm, obpiramidal. $n=16$.

Habitat, phenology and distribution: Grasslands on basic substrates, usually very clay soils; $10-200 \mathrm{~m}$; (V)VI-VIII. • Endemic to the S of Spain, in the Guadalquivir valley (Fig. 16). Spain: $\mathrm{Ca}$ Se.

\section{Selected specimens}

SPAIN. Cádiz: Cádiz, without date, Chaubert (G 104126). Cerca de Villamartín, 31-V-1969, E.F. Galiano E al. (SEV 161833); ibidem, en la carretera a El Bosque, 17-VI-2009, S. Talavera $\&$ al. (SEV 248711). Vejer de la Frontera, Caños de Meca, 15-V-1959, D.M.C. Brinton-Lee (SEV 81177). Villamartín, 8-V-2010, J. CanoMaqueda (SEV 256653). Sevilla: Carmona, J.M. Triguero (SEVhistórico 1077).

8. Campanula dieckii Lange in Overs. Kongel. Danske Vidensk. Selsk. Forh. Medlemmers Arbeider 1893: 195. 1893

Ind. loc.: "Ciudad Encantada mellem Uña og Val- decabras i Provinsen Cuenca, 1.juni 1892 blomstrencle (Dieck)!".Type: Spain. Cuenca, Uña, 1 June 1892, Dieck s.n. (lectotype, here designated, C, herb. J. Lange, Fig. 18; see observations).

C. matritensis var. nevadensis A. DC. in DC., Prodr. 7(1): 481. 1838. Ind. loc.: "in editioribus SierraeNevadae. (Boiss.!)”. Type: Spain. Granada, Sierra Nevada, 1838, Boissier s.n. (lectotype, here designated, G138396!; see observations).

C. semisphaerica Pau, Not. Bot. Fl. Españ. fasc. 6: 76. 1896. Ind. loc.: "Sacañet, á $1100 \mathrm{~m}$ de alt. en compañía de la C. dichotoma; 8 julio 1895 ”. Type: Spain. Castellón, Sacañet, 8 July 1895, Pau s.n. (lectotype, here designated, MA121465!; see observations).

C. argutidens Porta et Rigo, Iter. Hisp. III: n. ${ }^{\circ} 309$ (1891), in sched., nom. nud.

C. specularioides var. argutidens Porta et Rigo, Iter. Hisp. III: nº 309 (1891), in sched., nom. nud.

Illustrations: Sáez \& Aldasoro (2001: 132, fig. 40, as C. decumbens); Fig. 15 E, F.

Herb (3)8-20(30) cm, annual, erect, usually branched in upper half, often densely pubescent, at least in the lower half. Stem angled, little branched, densely pubescent, with \pm antrorse setose hairs, 0.1$0.7 \mathrm{~mm}$, sometimes glabrescent at the apex. Leaves somewhat fleshy, crenate, lobed or pedate, sometimes the uppermost subentire; middle cauline leaves (4)7$18 \times 3-9(14) \mathrm{mm}, \pm$ elliptical, sessile, subauriculate, densely pubescent, with hairs 0.1-0.7 $\mathrm{mm}$; upper cauline leaves 3-13.5 × 0.5-2.5(7.7) mm, \pm lanceolate, sessile, subauriculate, glabrous or more often with scattered hairs 0.1-0.6 mm. Inflorescence paniculate, lax. Flowers pedicellate; pedicel (11.9)19-90(155) $\mathrm{mm}$, glabrous or papillose on top. Calyx-teeth (2.3) 3-10.5 $\times$ 0.7-1.5 mm, lanceolate, obtuse, with thickened margins. Corolla (6.6)8-13.7 mm, infundibuliform, with the tube much shorter than the lobes; tube (1.5)3-4.5 mm, light blue with white base; lobes 7 $12.3 \times(3) 4-5.5(7.6) \mathrm{mm}$, ovate-lanceolate, blue, with three purple nerves. Stamens with enlarged base of 1.1-1.9 $\times 1.5-1.9 \mathrm{~mm}$; filaments $0.6-0.7 \mathrm{~mm}$; anthers 2.1-3(3.8) $\mathrm{mm}$, whitish. Ovary glabrous, papillose or densely hairy, with setose hairs of (0.2)0.7-2.2 mm; style 2.1-4(4.7) $\mathrm{mm}$, glabrous, with three stigmas; stigmas (2.1)2.5-4 mm, erect-patent at anthesis, \pm straight. Capsule (3.5)4.9-9(11.5) $\times 3.5-6.5 \mathrm{~mm}$, obpyramidal, longer than wide, from papillose to densely hairy, with setose hairs of $0.3-1 \mathrm{~mm}$, with 10 very wide nerves like flat ribs, dehiscing by three middle position pores. Seeds $0.5-0.8 \times 0.2-0.3 \mathrm{~mm}$, ovoid, shining, yellowish to brown. $2 n=28$. 
Habitat, phenology and distribution: Wet meadows and kermes oak woodlands on basic substrates (gypsum, limestone and dolomite); 600-2300 m. VIVII(VIII). • Endemic to the Iberian Peninsula, C, E and SE Spain, where it is frequent, and rare in $\mathrm{CW}$ Portugal, Serra do Sintra (Fig. 16). Portugal: E. Spain: $\mathrm{Ab} \mathrm{Al} \mathrm{Bu} \mathrm{Cs} \mathrm{CR} \mathrm{Cu} \mathrm{Gr} \mathrm{Gu} \mathrm{J} \mathrm{Lo} \mathrm{M} \mathrm{Ma} \mathrm{Mu} \mathrm{Sa} \mathrm{Sg} \mathrm{So}$ To Va ZZa.

Observations: This species has been confused with C. decumbens by several authors. Cuatrecasas (1929) commented: "Las diferencias que separan a la planta de De Candolle [C. decumbens] de la de Loefling [C. lusitanica] son mínimas. La primera son simplemente formas de tallos menos ramificados y lacinias calicinales más anchas que en la última, la cual, en general, también difiere por su mayor estrechez de la corola. Estos caracteres están, sin embargo, sujetos a variaciones, lo mismo que la vestidura del tubo de los cálices entre unos muy híspidos y otros muy lampiños". However, in this comment Cuatrecasas is referring to three different species from the Sierra de Má-

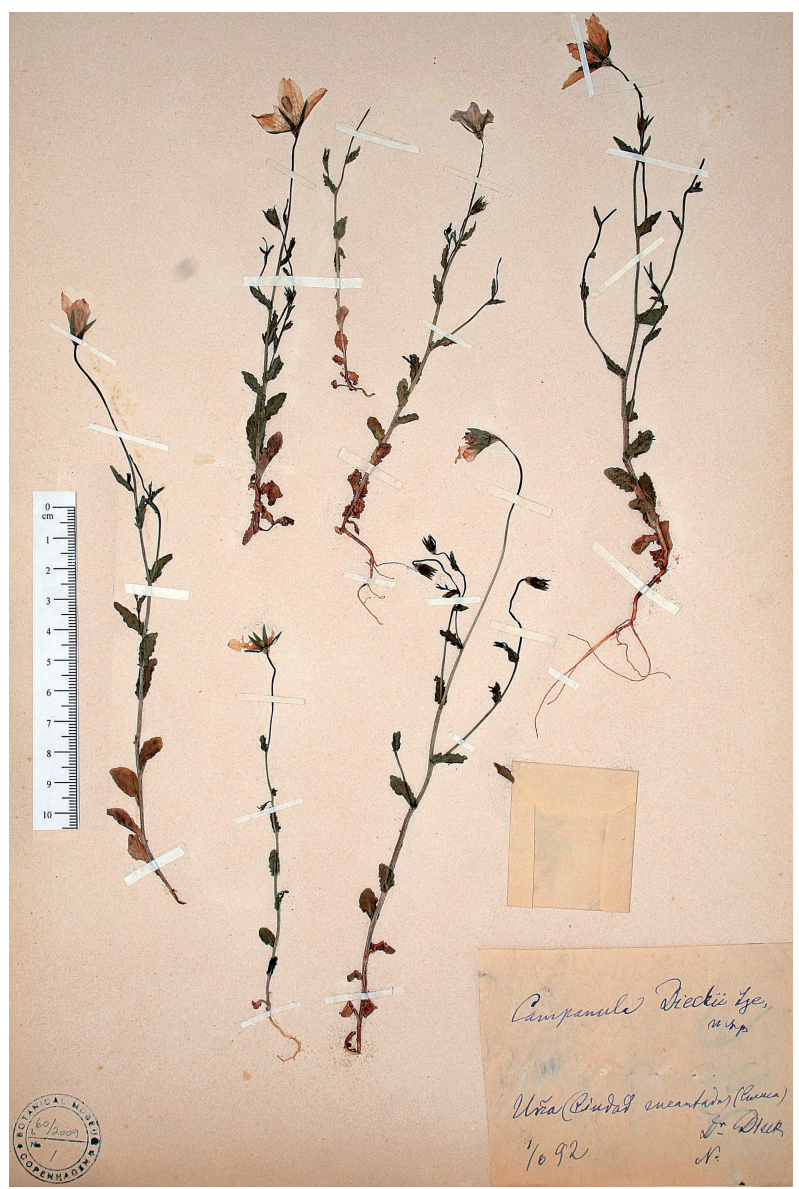

Fig. 18. Lectotype (in the upper left corner) and isolectotypes (the rest of plants) of Campanula dieckii (C, herb. Lange). gina (Jaen): C. matritensis with a glabrous ovary, and C. cabezudoi and C. dieckii, both with very hairy, almost hispid ovary.

We have seen material of this species from two collections from Sintra (Estremadura, Portugal). One collected by F. Fernandes in V-1914 (G 104249, 104150; LISU 36374; MA 121500), distributed in exiccata by F. Sennen (in F. Sennen Pl. Esp. n. ${ }^{\circ}$ 6006), and another by W. Rothmaler on 13-V-1938 (G 104148; LISE 4368). Since this plant has not been collected again at this locality, the presence of this species as a native in Portugal may be considered doubtful. However, this kind of disjunction is not uncommon in other species of the Iberian Peninsula, i.e., Silene distichia Willd., a common species in the Eastern half of Spain and rare in the W Portugal (Talavera, 1990).

The type material of Campanula dieckii is composed by 7 whole plants at anthesis of $10-20 \mathrm{~cm}$ with sessile, elliptic, crenate cauline leaves, infundibuliform corolla, glabrous style, straight stigma and densely setose ovary. The sheet also contains two flowers in an envelope. The first plant, in the upper left corner of the sheet is chosen as lectotype, because it is the one that best fits the description of the author. The other six plants are isolectotypes (see Fig. 18). In the Geneva herbarium there is a sheet (G104244) with three plants that are also isolectotypes.

The sheet of type material of $C$. matritensis var. nevadensis contains 6 plants in flower. We have chosen as lectotype the plant placed at the top right, about $10 \mathrm{~cm}$, very hairy, with crenate leaves and two flowers in anthesis. The remaining plants are isolectotypes.

The type material of $C$. semisphaerica consists of two very small plants, each with one flower open. The plant on the right is the lectotype. On the sheet there is a typed label by Ginés López-González dated 1311-1979 indicating the material contained on the sheet as holotype. Pau's indication "genuine" may be understood that this material was chosen as type by the author of the binomial.

\section{Selected specimens}

PORTUGAL. Estremadura: Sintra, V-1914, F. Fernandes, in F. Sennen, Plantes D'Espagne, 1926, nº 6006 (G 104150, G 104249, LISU 36374, MA 121500, MA 474598); ibidem, 13-V-1938, W. Rothmaler, in W. Rothmaler, Flora Lusitanica $n^{\circ} 13133$ (G 104148, LISE 4368).

SPAIN. Albacete: Alcaraz, La Molata, 24-V-1993, B. Casaseca E M.A. Carrasco (MA 531238). Alrededores de Santa Elena de Ruidera, 24-V-1933, González Albo (MA 121567). El Ballestero, 28-VI-1935, González Albo (MA 432730). El Cascajal, 24-V-1933, González Albo (MA 121480, MA 121479). Pontegruelos, 28-VI1935, González Albo (MA 432731). Tús, vertiente SE del Calar del Mundo, 29-V-1987, E. Villanueva E al. (MA 393151). Villaverde 
de Guadalimar, 18-VI-1969, P.E. Gibbs (SEV 161752). Almería: Bacares, 4-VI-1929, E. Gros (MA 433604). De Bacares a la Venta de Lleiva, 5-VI-1929, E. Gros (MA 433605). Burgos: Ciruelos de Cervera. Pie del Alto de la Cabeza, 11-VII-1979, Pons Sorolla E Susanna (MA 413025). Hortezuelos, 17-VI-1982, M.A. Carrasco E M. Velayos (MA 312710, SALA 32983). Huidobro, 5-VII-1987, Galán Cela \& A. Martín (MA 639955). Tejada. Pico Valdosa, $3-$ VII-1979, J. Fernández Casas E al. (MA 413017). Ciudad Real: La Molata, 2-VI-1934, González Albo (MA 201345). Cuenca: Barajas de Melo, valle del río Calvache, pr. Urbanización Valderíos, $580 \mathrm{~m}$, 30-V-1998, V.J. Arán E M.J. Tohá (MA 614852. MA 620787). Pinar de Beteta, 8-VII-1932, A. Caballero (MA 121464). Talayuelas, 1100m, 18-VI-1979, G. Mateo (MA 256531). Granada: Alhama de Granada, Barranco del Malinfierno, 17-VI-2004, B. Cabezudo E al. (MGC 59291). Arenas del Rey, El Cenacho, 3-VI2004, B. Cabezudo \& al. (MGC 59289). Ascenso a Sierra Nevada, falla del Purche, 8-V-1966, S. Silvestre (SEV 19702). Guadix, 11 VI-1921, E. Gros (MA 31778). Sierra de Albuñuelas, 15-VI-1976, A. Asensi \& P. Díez (MGC 3617). Sierra de Baza, ascenso a Santa Bárbara, 21-VI-1988, S. Talavera E al. (G 104091). Sierra de Castril, VI-1903, E. Reverchon., in E. Reverchon, Plantes d'Espagne 1903: no 1209 (G 104074, MA 121523). Sierra de Cázulas, 23-VI1976, Ladero E al. (MA 204705, SALA 8787). Sierra de Guillimona, Cuerda de los Mirabetes, 23-VI-1988, S. Talavera \& al. (G 104059). Huéscar, Sierra de la Sagra, cara sur, 14-VI-1995, B. Cabezudo E al. (MGC 39893). Padul, 4-VI-1980, M. Ladero E al. (SALA 92232). Sierra del Pinar, without date, Reverchon (G 104076). Sierra Nevada, Trevenque, VI-1973, J. Fernández-Casas (G 104078, SEV 19866). Guadalajara: Codes, 21-VI-1988, M.A. Carrasco \& M. Velayos (MA 711892). Sacecorbo, 9-VI-1973, A. Segura Zubizarreta (G 104064, MA 269833). Tamajón, alrededores de la ermita de los Enebrales, 4-VII-1978, M.A. Rivas E C. Soriano (MA 385718). Torremocha del Pinar, 19-VI-1995, M.A. Martín Ballesteros (SALA 59846). Jaén: between Tobos and Vites, bed of river Zumeta, 25-VI-1988, S. Talavera \& al. (G 104058). Cambil, Sierra de Mágina, Matabegí, 15-VI-1995, B. Cabezudo E al. (MGC 39707). Cazorla, aledaños de la C. F. Fuente del Oso, 31-V-1976, F. Muñoz Garmendia \& C. Soriano (MA 454856). La Iruela, barranco de Guadahornillos, 16-VI-1976, F. Muñoz Garmendia \& C. Soriano (MA 454825). Las Altarillas, 16-VI-1941, E. Guinea (MA 432654). Orcera, 6-VI-1980, C. Soriano (MA 592112). Pozo Alcón, pico de Cabañas, 20-VI-1975, F. Muñoz Garmendia \& C. Soriano (MA 454823). Santiago de la Espada, cabecera del arroyo del Membrillo, 5-VI-1975, F. Muñoz Garmendia \& C. Soriano (MA 454816). Segura de la Sierra, 17-VI-1850, E. Bourgeau, in E. Bourgeau, Pl. d' Espagne, 1850: nº 992 (G 104100). Sierra del Pozo, VI-1905, E. Reverchon, in E. Reverchon, Plantes d'Espagne 1905: no 1209 (G 104134). Sierra Mágina, entre el Cortijo de los Prados y Cerro Carceles, 11-VI-1987, E. Villanueva \& al. (MA 401189). Siles, VI-1850, M. Blanco (G 104113). Madrid: Algodor, 31-V-1925, A. Caballero E González Guerrero (MA 432742, MA 432744). Aranjuez, V-1897, C. Pau (MA 121457). Idem, 25-V1919, C. Vicioso (MA 121459). Arganda, IV-1932, C. Pau (MA 432687). Piul de Rivas, V-1915, C. Vicioso (MA 121456). Venta del Gorro, 1802, Lagasca (G 138462). Málaga: Alcaucín. Sierra Tejeda, loma de las Víboras, 7-VI-2002, D. Navas E al. (MGC 52239). Alfarnate, 30-III-2007, (SEV256652). Canillas de Albaida, Los Horcajos, puerto de la Orza, 5-VI-1919, E. Gros (MA 121468). Castillo de Frigiliana, VI-1919, E. Gros (MA 121467). Cómpeta, Navachica, 22-VI-2004, B. Cabezudo E al. (MGC 59293). Sedella, 14-VI-1994, A. Aparicio \& al. (MA 543877). Sierra Tejeda, V1914, E. Gros (MA 121471). Murcia: Sierra de Moratalla, Revolcadores, 15-VII-1974, A. Charpin E J. Fernández. Casas (G 104079). Salamanca: Ledesma, 19-V-1976, J. Sánchez (MA 219750). Molinillo, 1859, Sainz (MA 153143). Segovia: Cedillo de la Torre, 5-VI-1985, A.R. Burgaz E A. Izuzquiza (MA 306519).
Fuentidueña, 24-VI-1983, T. Romero (SALA 41198). Lastras de Cuéllar, Molino Ladrón, 840 m, 24-V-1998, P. Bariego Hernández E A. Gastón González (MA 754470). Villaseca, 12-VI-1983, T. Romero (SALA 41951). Soria: Andaluz, 26-VI-1975, A. Segura Zubizarreta (FCO 7873, SEV 69199). Cañón del río Lobos, 17-VI1982, A. Buades (MA 502178). Herrera de Soria, 30-VI-1983, A. Buades (MA 504408). Ucero, cuesta de la Galiana, 28-V-1983, A. Buades (MA 504043). Toledo: Toledo, 22-V-1897, C. Pau (MA 121458). Valladolid: Castronuño, 20-VI-1984, F.J. González \& C. J. Valle (SALAF 7361). Encinas de Esgueva, 7-VII-1983, J.L. Fernández Alonso (MA 517691). Rábano, 15-VI-1983, T. Romero (SALA 41197). Urueña, 20-VI-1980, Fernández Díez (SALA 22002). Valladolid, 17-VI-1906, Sennen (MA 121463). Zamora: Castrillo de la Guareña, 30-V-1983, X. Giráldez (SALA 31601). Zaragoza: Calatayud, 15-VI-1910, C. Vicioso (G 104095, MA 121462). Cerros de Andrés, VI-1898, C. Vicioso (MA 121460).

\section{Acknowledgements}

We thank Drs. B. Cabezudo (Málaga, Spain), the late S. Castroviejo (Madrid, Spain) and E. Rico (Salamanca, Spain) for their help in field collections. We are grateful to curators of the cited herbaria for the loan of specimens. We are also grateful to Dr. Peter Gibbs (St. Andrews, UK) for reviewing the manuscript. This work has been financed by grants from the Ministerio de Educación y Ciencia to M. Arista (REM2002-04354-C02-02 and CGL2005-01951), to S. Talavera (CGL2006-00817 and CGL2009-08178) and by a predoctoral grant to J. Cano-Maqueda (BES-2003-0332).

\section{References}

Bentham, G. \& Hooker, J.D. 1876. Genera Plantarum, vol. 2. London.

Boissier, E. 1839. Voyage botanique dans le midi de L'Espagne pendant l'année 1837, vol. 2: 1-480. Paris.

Boissier, E. 1875. Flora Orientalis, vol. 3: 893-945. Genève, Basel.

Borsch, T., Korotkova, N., Raus, T., Lobin, W. \& Löhne, C. 2009. The petD group II intron as a species level marker: utility for tree inference and species identification in the diverse genus Campanula (Campanulaceae). Willdenowia 39: 7-33.

Brotero, F.A. 1800. Phytographia Lusitaniae Selectior, fasc. I. Olissipone.

Brotero, F.A. 1804. Flora Lusitanica, vol. 1. Olissipone.

Brotero, F.A. 1816. Phytographia Lusitaniae Selectior, vol. 1. Olissipone.

Caballero, A. 1942. Apuntes para una flórula de la Serranía de Cuenca. Anales del Jardín Botánico de Madrid 2: 236-265.

Cano-Maqueda, J., Talavera, S., Arista, M. \& Catalán, P. 2008. Speciation and biogeographical history of the Campanula lusitanica complex (Campanulaceae) in the Western Mediterranean region. Taxon 57: 1252-1266.

Cellinese, N., Smith, S.A., Edwards, E.J., Kim, S.T., Haberle, R.C., Avramakis, M. \& Donoghue, M.J. 2009. Historical biogeography of the endemic Campanulaceae of Crete. Journal of Biogeography 36: 1253-1269.

Contandriopoulos, J. 1964a. Recherches sur la flore endémique de la Corse et sur ses origines II. Revue Générale Botanique (Paris) 71:361-384.

Contandriopoulos, J. 1964b. Contribution a l'etude caryologique des Campanulaceas de Grece. Bulletin de la Société Botanique de France 111: 222-235 
Contandriopoulos, J. 1966. Contribution a l'etude caryologique des Campanulaceas de Grece II. Bulletin de la Société Botanique de France 113: 453-474.

Cuatrecasas, J. 1929. Estudios sobre la flora y la vegetación del Macizo de Mágina. Trabajos del Museo de Ciencias Naturales de Barcelona, Ser. Bot. 12: 7-510.

Damboldt, J. 1965. Campanula tommasiana Koch und C. waldsteiniana R. et S.: Zur Zytotaxonomie zweier mediterraner Reliktsippen. Österreichische Botanische Zeitschrift 112: 392-406.

Damboldt, J. 1976. Materials for a Flora of Turkey XXXII: Campanulaceae. Notes from the Royal Botanical Garden, Edinburgh, 35:39-52.

Damboldt, J. 1978. Campanula. In: Davis, P.H. (ed.), Flora of Turkey and East Aegean Islands, vol. 6: 2-64.University Press, Edinburgh

DeBry, R.W. \& R.G. Olmstead. 2000. A simulation study of reduced tree-search effort in bootstrap resampling analysis. Systematic Biology 49: 171-179.

De Candolle, A. 1830. Monographie des Campanulées. Paris.

De Candolle, A. 1838. Campanulaceae. In: De Candolle, A.P. (ed.), Prodromus Systematis Naturalis Regni Vegetabilis, vol. 7: 414-496. Paris.

Eddie, W.M.M., Shulkina, T., Gaskin, J., Haberle, R.C. \& Cansen, R.K. 2003. Phylogeny of Campanulaceae s. str. inferred from its sequences of nuclear ribosomal DNA. Annals of the Missouri Botanic Garden 90: 554-575.

Endlicher, S. 1838. Genera Plantarum. Vindobonae.

Fedorov, A.A. 1957. Campanulaceae. In: Shiskin, B.K. (ed.). Flora USSR, vol. 24: 126-450. Moskva-Leningrad.

Fedorov, A.A. 1976. Campanula. In: Tutin, T.G., Heywood, V.H., Burges, N.A., Moore, D.M., Valentine, D.H., Walters, S.M. \& Webb, D.A. (eds.). Flora Europaea, vol. 4: 74-93. Cambridge University Press, Cambridge.

Felsenstein, J. 1985. Confidence limits on phylogenies: an approach using the bootstrap. Evolution 39: 783-791.

Fernandes, A. 1962. Sobre a cariologia de Campanula lusitanica L. ex Loefl. e C. transtagana R. Fernandes. Boletim da Sociedade Broterian, sér. 2, 34: 129-137.

Fernández, M.P., Narbona, F.E., Ortiz, M.A., Talavera, S. \& Salgueiro, F.J. 2001. Números cromosomáticos de plantas occidentales. Anales Jardín Botánico de Madrid 58: 341-345.

Gallego, M.J. 1986. Números cromosómicos para la flora española, $n^{\circ}$ 464-470. Lagascalia 14: 286-288.

Gallego, M.J. 1987. Campanula. In: Valdés, B., Talavera, S. \& Galiano, E.F. (eds.). Flora de Andalucía Occidental, vol. 2: 564265. Ketrès, Barcelona.

García Martín, F. \& Silvestre, S. 1985. Números cromosómicos para la flora española n ${ }^{\circ}$ 409-421. Lagascalia 13:313-318.

Goldblatt, P. 1985. Index to plant chromosome numbers 19821983. Monographs in Systematic Botany from the Missouri Botanical Garden 13: 1-224.

Goldblatt, P. \& Johnson, D.E. 1990. Index to plant chromosome numbers 1986-1987. Monographs in Systematic Botany from the Missouri Botanical Garden 30: i-ix, 1-124.

Goldblatt, P. \& Johnson, D.E.. 1994. Index to plant chromosome numbers 1990-1991. Monographs in Systematic Botany from the Missouri Botanical Garden 51: i-ix, 1-267.

Haberle, R.C., Dang, A., Lee, T., Penaflor, C., Cortes-Burn, H., Oestreich, A., Raubenson, L., Cellinese, N., Edwards, E.J. \& Kim, S.T. 2009. Taxonomic and biogeographic implications of a phylogenetic analysis of the Campanulaceae based on three chloroplast genes. Taxon 58: 715-734.
Hoffmannsegg, J.C.C. \& Link, H.F. 1820-1824. Flore Portugaise, vol. 2 (17-18): 14 Berlin.

Hoffmannsegg, J.C.C. \& Link, H.F. 1820. Flore Portugaise, vol. 2: pl. 82. Berlin.

Huelsenbeck, J.P. \& Ronquist, F. 2002. MRBAY ES. Bayesian inference of phylogeny. V.3.0. Bioinformatics 17: 754-755.

Lammers, T.G. 2007a. Campanulaceae. In: Kadereit, J.W. \& Jeffrey, C. (eds.), The families and genera of vascular plants. Flowering Plants. Monocots. Asteridae, vol. 8: 26-56. Springer-Verlag, Berlin.

Lammers, T.G. 2007b. World Checklist and bibliography of Campanulaceae. Royal Botanic Gardens, Kew.

Lange, J. 1893. Nye Bidrag til Spaniens Flora Overs-Kongel. Danske Videnskabernes Selskabs Forhandlinger og dets Medlemmers Arbeider 1893: 191-207.

Larsen, K. 1954. Chromosome numbers of some European flowering plants. Botanisk Tidsskrift 50: 163-174.

Larsen, K. 1956. Chromosome studies in some mediterranean and south European flowering plant. Botaniska Notiser (Lund) 109: 293-307.

Leaché, A.D. \& Reeder, T.N. 2002. Molecular systematics of the Eastern fence lizard (Sceloporus undulatus): a comparision of parsimony, likelihood, and bayesian approaches. Systematic Biology 51: 44-68.

Levan, A., Fredga, K. \& Sandberg, A. 1964. Nomenclature for centromeric position on chromosomes. Hereditas 52: 201-220.

López-González, G. 1979-1980. Dos campánulas españolas: C. decumbens DC. $\mathrm{y}$ «C. mollis L.». Boletim da Sociedade Broteriana, sér. 2, 53: 299-308.

Merxmüller, H. \& Damboldt, J. 1962. Die chromosomenzahlen einiger rupicoler mediterraner Campanulae. Berichte der Deutschen Botanischen Gesellscaft 75: 233-236.

Park J.M., Kovačič, S., Liber, Z., Eddie, W.M.M. \& Schneeweiss, G.M. 2006. Phylogeny and Biogeography of Iophyllous Species of Campanula (Campanulaceae) in the Mediterranean area. Systematic Botany 31: 862-880.

Pau, C. 1896. Notas botánicas a la flora española, fasc. 6. Segorbe.

Pau, C. 1921. Notas sueltas sobre la flora matritense. Boletín de la Sociedad Ibérica de Ciencias Naturales 20: 176-191.

Pau, C. 1924. Plantas del norte de Yebala (Marruecos). Memorias de la Real Sociedad Española de Historia Natural 12: 263-401.

Podlech, D. \& Damboldt, J. 1964. Zytotaxonomische Beiträge zur Kenntnis der Campanulaceen in Europa. Berichte der Deutschen Botanischen Gesellschaft 7(9): 360-369.

Rambaud, A. 1996. Sequence Alignment Editor (Se-Al). Ver. 1.0 alpha 1. Oxford University, Oxford.

Roquet, C., Sáez, L., Aldasoro, J.J., Susanna, A., Alarcón, M.L. \& García-Jacas, N. 2008. Natural delineation, molecular phylogeny and floral evolution in Campanula. Systematic Botanic 33: 203-217.

Roquet, C., Sanmartín, I., García-Jacas, N., Sáez, L., Susanna, A., Wikström, N. \& Aldasoro, J.J. 2009. Reconstructing the history of Campanulaceae with a Bayesian approach to molecular dating and dispersal-vicariance analyses. Molecular phylogenetics and Evolution 52: 575-587.

Rouy, G. 1908. Flore de France 10: 59-82. Paris.

Sáez, L. \& Aldasoro, J.J. 2001. Campanula. In: Paiva, J., Sales, F., Hedge, I., Aedo, C., Aldasoro, J.J., Castroviejo, S., Herrero, A. \& Velayos, M. (eds.), Flora iberica, vol. 14: 105-136. CSIC, Madrid.

Sáez, L. \& Aldasoro, J.J. 2003. A taxonomic revision of Campanula L. subgenus Sicyocodon (Feer) Damboldt and subgenus Megalocalyx Damboldt (Campanulaceae). Botanical Journal of the Linnean Society 141: 215-241. 
Schultes, J.A. \& Roemer, J.J. 1819-1820. In: Roemer, J.J. \& Schultes, J.A. (eds.), Systema Vegetabilum, vol. 5: 104. Stuttgart.

Snow, R. 1963. Alcoholic hydrochloric acid-carmine as a stain for chromosomes in squach preparations. Biotechnic \& Histochem istry 38: 9-13.

Stebbins, G.L. 1938. Cytological characteristics associated with the different growth habits in the dicotyledons. American Journal of Botany 25: 189-198.

Stefanović, S. \& Lakušić, D. 2009. Molecular reappraisal confirms that the Campanula trichocalycina-pichleri complex belongs to Asyneuma (Campanulaceae). Botanica Serbica 33: 21-31.

Susanna, A., García-Jacas, N., Hidalgo, O., Vilatersana, R. \& Garnatje, T. 2006. The Cardueae (Compositae) revisited: insights from ITS, trnL-trnF, and matK nuclear and chloroplast DNA analysis. Annals of the Missouri Botanical Garden 93: 150-171.

Swofford, D. L. 2002. PAUP*: Phylogenetic Analysis Using Parsimony and other methods. Ver. 4.0 beta 10. Sinauer, Sunderland.

Talavera, S. 1990. Silene. In: Castroviejo, S. \& al. (eds.), Flora iberica 2: 313-406, C.S.I.C., Madrid.

Torrecilla, P. \& Catalán, P. 2002. Phylogeny of broad-leaved and fine-leaved Festuca linajes (Poaceae) based on nuclear ITS sequences. Systematic Biology 27: 241-251.

Valdés, B., Talavera, S. \& Galiano, E.F. (eds.). 1987. Flora Vascular de Andalucía Occidental, vol. 2: 564. Editorial Ketrès, Barcelona.

White, T.J., Bruns, T., Lee, S. \& Taylor, J.W. 1990. Amplification and direct sequencing of fungal ribosomal RNA genes for phylogenetics. In: Innis, M.A., Gelfand, D.H., Sninsky, J.J. \& White, T.J. (eds.), PCR protocols; a guide to methods and applications, Academic Press, San Diego, California. pp.: 315-322.

Willkomm, H.M. 1868. Campanulaceae. In: Willkomm, H.M. \& Lange, J. (eds.), Prodromus Flora Hispanicea, vol. 2: 279-298. Stuttgartiae.

\section{Appendix 1}

\section{Species, origin of plant material, voucher, collector or reference and ITS GenBank accession no.}

Adenophora divaricata Franch. \& Sav.; cultivated in Royal Botanic Gardens Edinburgh; Eddie \& al. (2003); AY 322005 \& AY 331418. Asyneuma japonicum (Miq.) Briq.; Korea; Kim \& al. (1999); AF 183437 \& AF 183443. Azorina vidalii (Wats.) Feer.; cultivated in University of Edinburgh; Eddie \& al. (2003); AY 322007 \& AY 331420. Campanula alliarifolia Willd.; cultivated in Royal Botanic, Garden, Kew; Eddie \& al. (2003); AY 322008 \& AY 331421. C. alpina Jacq.; Austria, Niedere Tauern; Park \& al. (2006), DQ 304573. C. armazica Kharadze; Caucasus; Eddie \& al. (2003); AY 322009 \& AY 331422. C. arvatica Lag.; cultivated in University of Edinburgh; Eddie \& al. (2003); AY 322010 \& AY 331423. C. barbata L.; Italy; Eddie \& al. (2003); AY 32211 \& AY 331424. C. beckiana Hayek; Austria, Northeastern Alps; Park \& al. (2006); DQ 304619. C. bellidifolia Adams; Caucasus; Eddie \& al. (2003); AY 322012 \& AY 331425. C. bononiensis L.; Austria, Leithagebirge; Park \& al. (2006); DQ 304571. C. broussonetiana Schult.; Morocco, Tazzeka (Middle Atlas); Cano-Maqueda \& al. (2008); FM 212711. C. cabezudoi Cano-Maqueda \& Talavera; Spain, Málaga, Junquera; Cano-Maqueda \& al. (2008); FM 212727. C. carpatica Jacq.; USA, Illinois; Eddie \& al. (2003); AY 322013 \& AY 331426. C. cenisia L.; Austria, Lechtaler Alps; Park \& al. (2006); DQ 304622. C. cespitosa Scop.; Austria, Northeastern Alps; Park \& al. (2006); DQ 304621. C. decumbens A. DC. subsp. decumbens; (1): Spain, Málaga: Benaoján; Cano-Maqueda \& al. (2008); FM 212735. C. decumbens subsp. baetica Cano-Maqueda \& Talavera; (2): Spain, Cádiz, Villamartín; Cano-Maqueda; HQ 407547. C. dichotoma L.; Italy, Calabria, NW of Nicótera; Park \& al. (2006); DQ 304579. C. dieckii Lange; (1) Spain, Granada, Alhama de Granada; Cano-Maqueda \& al. (2008); FM 212733. C dieckii Lange; (2) Spain, Cuenca, Barajas de Melo; Roquet \& al. (2008) as C. decumbens; EF 090526 \& EF 090567.C. divaricata Michx.; USA, Virginia; Eddie \& al. (2003); AY 322014 \& AY 331427. C. drabifolia Sibth. \& Sm.; Greece, Ionian islands, Atokos; Park \& al. (2006); DQ 304578. C. edulis Forssk.; Saudi Arabia; Eddie \& al. (2003); AY 233015 \& AY 331428. C. elatines L.; Italy, Alpi Cozie; Park \& al. (2006); DQ 304624. C. elatinoides Moretti; Italy, Southern Alps; Park \& al. (2006); DQ 304625. C. erinus L.; Spain, Sevilla, Sevilla City; Cano-Maqueda \& al., (2008); FM 212737. C. fenestrellata Feer subsp. fenestrellata; Croatia, Velebit, Velika Paklenica; Park \& al. (2006); DQ 304592. C. fragilis subsp. cavolinni (Ten.) Damb.; Italy, Abruzzo; Park \& al. (2006); DQ 304629. C. garganica Ten. subsp. garganica; cultivated in Botanical Garden Zagreb (material from Italy); Park \& al. (2006); DQ 304596. C. glomerata L.; cultivated in University of Edinburgh; Eddie \& al. (2003); AY 322017 \& AY 331430. C. grossheimii Kharadze; Caucasus; Eddie \& al. (2003); AY 322018 \& AY 331431. C. hawkinsiana Hausskn. \& Heldreich; Eddie \& al. (2003); AY 322019 \& AY 331432. C. hercegovina Degen \& Fiala; Bosnia \& Herzergovina, Blidinje; Park \& al. (2006); DQ 304616. C. herminii Hoffmans. \& Link.; Portugal; Eddie \& al. (2003); AY 322020 \& AY 331433. C. isophylla Moertti; cultivated in Botanical Garden Zagreb (material from Italy); Park \& al. (2006); DQ 304630. C. justiniana Witasek; Croatia, Čabranka river; Park \& al. (2006); DQ 304613. C. kolenatiana C.A. Mey.; Caucasus; Eddie \& al. (2003); AY 322022 \& AY 331435. C. lanata Friv.; cultivated in University of Edinburgh; Eddie \& al. (2003); AY 322023 \& AY 331436. C. latifolia L.; Eddie \& al. (2003); AY 322024 \& AY 331437. C. lusitanica L.; (1): Spain, Orense, Rivadavia, R. Pino; HQ 407553. C. Iusitanica; (2): Portugal, Sierra de Monchique, Talavera \& al.; HQ 407550. C. lusitanica; (3): Portugal, Sierra de Monchique; Talavera \& al.; HQ 407551. C. Iusitanica L. (4): Spain, Pontevedra, Cangas de Morrazo, S. Castroviejo; HQ 407552. C. marchesettii Witasek; Croatia, Učka; Park \& al. (2006); DQ 304612. C. matritensis A. DC.; Spain, Huelva, Hinojos; Cano-Maqueda \& al. (2008) as C. lusitanica; FM 212703. C. mirabilis Albov; Royal Botanic Gardens Edinburgh; Eddie \& al. (2003); AY 322026 \& AY 331439. C. mollis L.; Spain; Eddie \& al. (2003); AY 322027 \& AY 331440. C. morettiana Rchb.; Italy, Dolomites; Park \& al. (2006); DQ 304602. C. ossetica Bieb.; Caucasus; Eddie \& al. (2003); AY 322028 \& AY 331441. C. patula L.; Spain, Huesca, Hecho (Pyrenees); Cano-Maqueda \& al. (2008); FM 212739. C. peregrina L.; Turkey; Eddie \& al. (2003); AY 322029 \& AY 331442. C. persicifolia L.; cultivated in University of Edinburgh; Eddie \& al. (2003); AY 322030 \& AY 331443. C. petraea L.; France; Eddie \& al. (2003); AY 322031 \& AY 331444. C. portenschlagiana Schultes; Croatia, Biokovo; Park \& al. (2006); DQ 304600. C. poscharskyana Degen; Croatia, Dubrovnik region; Park \& al. (2006); DQ 304601. C. primulifolia L.; (1): Portugal, Sirerra de Monchique, between Monchique and Odemira; Talavera \& al.; HQ 407555. C. primulifolia Brot.; (2): Spain, Huelva, Sierra de Aracena; Aldea de las Veredas, Arroyo del Acebuche; Talavera \& al.; HQ 407554. C. pulla L.; Austria; northeastern Alps; Park \& al. (2006); DQ 304605. C. punctata Lam.; cultivated in University of Edinburgh; Eddie \& al. (2003); AY 322033 \& AY 331446. C. pyramidalis L.; cultivated in University of Edinburgh; Eddie \& al. (2003); AY 322034 \& AY 331447.C. raddeana Trautv.; Caucasus; Eddie \& al. (2003); AY 
322035 \& AY 331448. C. raineri Perpenti; Italy, Alpi Bergamaschi; Park \& al. (2006); DQ 304604. C. ramosissima Sibth. \& Sm.; Greece, Lakonia; SALA 135597; Aedo \& al.; HQ 407548. C. rapuncuIus L.; Spain, Huelva, Hinojos; Cano-Maqueda \& al. (2008); FM 212738. C. reatina Lucchese; Italy, Turano Valley; Park \& al. (2006); DQ 304599. C. reverchonii A. Gray; USA, Texas; Eddie \& al. (2003); AY 322036 \& AY 331449. C. rotundifolia L.; Spain, Cádiz, Grazalema; Cano-Maqueda \& al. (2008); FM 212736. C. sarmatica Ker-Gawl.; Caucasus; Eddie \& al. (2003); AY 322038 \& AY 331451. C. siegizmundii Fed.; Caucasus; Eddie \& al. (2003); AY 322039 \& AY 331452. C. sosnowskyi Charadze; Caucasus; Eddie \& al. (2003); AY 322040 \& AY 331453. C. sparsa Friv.; Greece, Grevená, Palaiokastro; SALA 135596; Aedo \& al.; HQ 407549. C. specularioides Coss.; Spain, Cádiz, Grazalema; Cano-Maqueda \& al. (2008); FM 212705. C. spicata L.; Italy, Southern Alps; Park \& al. (2006); DQ 304574.C. stenocodon Boiss. \& Reuter; Italy, Alpi Cozie; Park \& al. (2006); DQ 304620. C. steveni Bieb.; Caucasus; Eddie \& al. (2003); AY 322041 \& AY 331454. C. thyrsoides L.; cultivated in University of Edinburgh; Eddie \& al. (2003); AY 322042 \& AY 331455. C. tommasiana Koch; Croatia, Učka; Park \& al. (2006); DQ 304611. C. transtagana R. Fern.; Spain, Córdoba, Azuel (Sierra Morena); Cano-Maqueda \& al. (2008); FM 212721. C. tridentata Schreb.; Caucasus; Eddie \& al. (2003); AY 322043 \& AY 331456. C. uniflora L.; Noeway, Sor-Trondelag; Park \& al. (2006); DQ 304588. C. versicolor Andrews; Greece, Ionian Islands, Kefallinía; Park \& al. (2006); DQ 304607; C. waldsteiniana Schultes; Croatia, Velebit Mtns.; Park \& al. (2006); DQ 304610. C. zoysii Wulfen; Slovenia, Kamniške Alps; Park \& al. (2006); DQ 304603. Campanulastrum americanum (L.) Small.; Eddie \& al. (2003); AY 322044 \& AY 331457. Canarina canariensis (L.) Vatke; Spain, Canary Islands; Eddie \& al. (2003); AY 322045 \& AY 331458. Codonopsis dicentrifolia W. W. Sm.; Nepal; Eddie \& al. (2003); AY 322046 \& AY 331459. Craterocapsa congesta Hilliard \& B.L. Burtt; Lesotho; Eddie \& al. (2003); AY 322049 \& AY 331462. Cynanthus lobatus Wall. ex Benth; Eddie \& al. (2003); AY 322050 \& AY 331463. Diosphaera rumeliana (Hampe) Bornm.; cultivated in University of Edinburgh; Eddie \& al. (2003); AY
322051 \& AY 331464. Edraianthus graminifolius (L.) A. DC.; cultivated in Royal Botanic Gardens Edinburgh; Eddie \& al. (2003); AY 322052 \& AY 331465. Feeria angustifolia (Schousb.) Buser; Morocco; Eddie \& al. (2003); AY 322054 \& AY 331467. Gadellia lactiflora (M. Bieb.) Schulkina; cultivated in Royal Botanic Gardens Edinburgh; Eddie \& al. (2003); AY 322055 \& AY 331468. Galactites tomentosa Moench.; Sussana \& al. (2006); AY 826285. Githopsis diffusa A. Gray; Eddie \& al. (2003); AY 322056 \& AY 331469. Hanabusaya asiatica Nakai; South Korea; Eddie \& al. (2003); AY 322057 \& AY 331470. Heterocodon rariflorum Nutt.; USA, California; Eddie \& al. (2003); AY 322058 \& AY 331471. Jasione montana L.; Spain; Eddie \& al. (2003); AY 322062 \& AY 331475. Legousia falcata (Ten.) Fritsch; cultivated in Royal Botanic Gardens Edinburgh and University of Texas; Eddie \& al. (2003); AY 322064 \& AY 331477. Leptocodon gracilis Lem.; Nepal; Eddie \& al. (2003); AY 322066 \& AY 331479. Michauxia tchihatcheffii Fisch. \& C.A. Mey.; cultivated in Royal Botanic Gardens Edinburgh; Eddie \& al. (2003); AY 322068 \& AY 331480. Musschia aurea Dumort.; cultivated in Royal Botanic Gardens Edinburgh and University of Texas; Eddie \& al. (2003); AY 322067 \& AY 331481. Petromarula pinnata(L.) A. DC.; Greece; Eddie \& al. (2003); AY 322069 \& AY 331482. Physoplexis comosa (L.) Schur; cultivated in Royal Botanic Gardens Edinburgh; Eddie \& al. (2003); AY 322070 \& AY 331483. Phyteuma orbiculare L.; Eddie \& al. (2003); AY 322071 \& AY 331484. Roella ciliata L.; Eddie \& al. (2003); AY 322074 \& AY 331487. Symphyandra armena (Stev.) A. DC.; cultivated in Royal Botanic Gardens Edinburgh; Eddie \& al. (2003); AY 322075 \& AY 331488. Trachelium caeruleum L.; cultivated in University of Edinburgh; Eddie \& al. (2003); AY 322078 \& AY 331491. Triodanis leptocarpa (Nutt.) Nieuwl.; USA, Texas; Eddie \& al. (2003); AY 322079 \& AY 331492. Wahlenbergia hederacea L.; Portugal, Sierra de Monchique, Talavera \& al.; HQ 407556.

Associate Editor: C. Aedo Received: $27-\mathrm{X}-2010$ Accepted: 25-I-2011 